\title{
ISSN 2500-3690
}
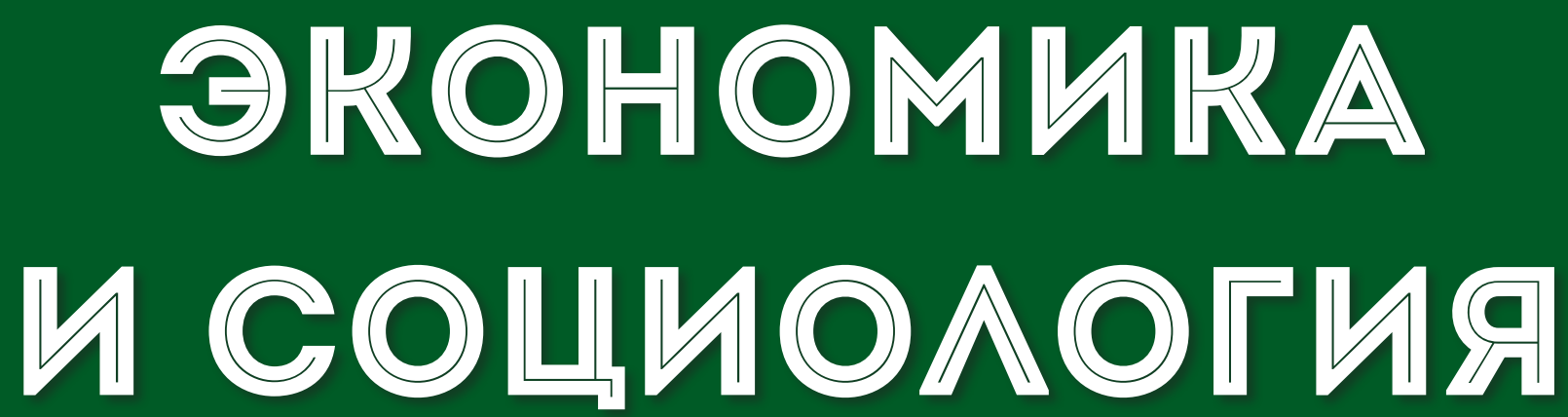

№4 (40)

2018 


\section{Редакционный совет:}

Барков С.А. - доктор социологических наук, профессор, заведующий кафедрой социологии организаций и менеджмента социологического факультета МГУ им. М.В. Ломоносова

Зельднер А.Г. - доктор экономических наук, профессор Института экономики Российской академии наук

Зубков В.И. - доктор социологических наук, профессор Московского авиационного института (национальный исследовательский университет)

Кетова Н.П. - доктор экономических наук, профессор, Заслуженный деятель науки РФ, заведующая кафедрой «Маркетинг и коммуникации в бизнесе» Южного федерального университета

Мамедов О.Ю. - доктор экономических наук, профессор Южного федерального университета

Мостовая И.В. - доктор социологических наук, профессор Южного федерального университета

Рязанова O.E. - доктор экономических наук, профессор кафедры экономической теории Московского государственного института международных отношений (университета) Министерства иностранных дел Российской Федерации (МГИМО), главный редактор журнала «Экономика и социология»

Силласте Г.Г. - доктор филосовских наук, профессор, зав. кафедрой «Теоретическая социология» Финансового университета при Правительстве Российской Федерации

Сильвестров С.Н. - доктор экономических наук, профессор, Директор Института экономической политики и проблем экономической безопасности, професcop Департамента мировой экономики и мировых финансов Финансового университета при Правительстве РФ

\section{Главный редактор}

Рязанова О.Е. - доктор экономических наук, професcop

\section{Компьютерная правка и верстка}

Голубев А.С.

Учредитель: ООО «Экономические науки»

Адрес: 125057, г. Москва, Чапаевский пер., 3-775

E-mail: info@esjournal.ru

Сайт: http://esjournal.ru

Свидетельство о регистрации средства массовой информации: ПИ № ФС77-64819 от 2 февраля 2016 г.

Подписной индекс 80674 (Агентство «Роспечать»)

ISSN: $2500-3690$

Дата выхода издания 29.11.2018

Формат 60х84/8

Усл. печ. л. 7.79

Тираж 500 экз.

Отпечатано в типографии ООО «24 Принт»

\section{Редакционная коллегия:}

Абрамов А.П. - доктор социологических наук, доцент кафедры философии и социологии Юго-Западного государственного университета

Авдошина Н.В. - кандидат социологических наук, доцент кафедры социологии и политологии Самарского университета, директор НИИ социальных технологий

Алексеев А.А. - доктор экономических наук, профессор, Директор Центра инновационного развития, Профессор кафедры экономики и управления предприятиями Санкт-Петербургского государственного экономического университета

Барков С.А. - доктор социологических наук, професcop, заведующий кафедрой социологии организаций и менеджмента социологического факультета МГУ им. М.В.Ломоносова

Валиева Е.Н. - доктор экономических наук, профессор Самарского государственного экономического университета

Зубков В.И. - доктор социологических наук, профессор Московского авиационного института (национальный исследовательский университет)

Кетова Н.П. - доктор экономических наук, профессор, Заслуженный деятель науки РФ, заведующая кафедрой «Маркетинг и коммуникации в бизнесе» Южного федерального университета

Корищенко К.Н. - доктор экономических наук, профессор, заведующий кафедрой фондовых рынков и финансового инжиниринга Факультета финансов и банковского дела РАНХиГС

Мамедов О.Ю. - доктор экономических наук, профессор Южного федерального университета

Михайлов А.М. - доктор экономических наук, профессор Самарского государственного экономического университета

Мостовая И.В. - доктор социологических наук, профессор Южного федерального университета

Рязанова О.Е. - доктор экономических наук, профессор кафедры экономической теории Московского государственного института международных отношений (университета) Министерства иностранных дел Российской Федерации (МГИМО), главный редактор журнала «Экономика и социология»

Савинова B.A. - доктор экономических наук, профессор кафедры финансов и кредита Самарского государственного экономического университета

Силласте Г.Г. - доктор филосовских наук, профессор, зав. кафедрой «Теоретическая социология» Финансового университета при Правительстве Российской Федерации

Сильвестров С.Н. - доктор экономических наук, профессор, Директор Института экономической политики и проблем экономической безопасности, профессор Департамента мировой экономики и мировых финансов Финансового университета при Правительстве РФ

Фомина Н.Е. - доктор экономических наук, зам. главного редактора журнала «Экономика и социология»

Хансевяров Р.И. - доктор экономических наук, профессор Самарского государственного экономического университета 



\section{СОДЕРЖАНИЕ}

\section{социология}

\section{ТЕОРИЯ, МЕТОДОЛОГИЯ И ИСТОРИЯ СОЦИОЛОГИИ}

Мостовая И.В. Востребованность методологии социального познания 7

Митрофанова С.Ю. Проблематика событийности детства в зарубежных журналах 11

\section{СОЦИАЛЬНАЯ СТРУКТУРА, СОЦИАЛЬНЫЕ ИНСТИТУТЫ И ПРОЦЕССЫ}

Соболева И.В. Конкурентоспособность женщин на рынке труда в свете глобальных трендов

\section{ЭКОНОМИКА. ЭКОНОМИЧЕСКИЕ НАУКИ}

\section{ЭКОНОМИЧЕСКАЯ ТЕОРИЯ}

Осипов В.С. Аграрная политика в странах с развивающейся экономикой: выбор институционального направления

Перепёлкин В.А., Фролова К.А., Мухамадиева Л.Н. Краудинвестинг как новый способ финансирования инновационных проектов

\section{ЭКОНОМИКА И УПРАВЛЕНИЕ НАРОДНЫМ ХОЗЯЙСТВОМ}

Базадзе Н.Г. Формирование организационной культуры корпораций оборонных отраслей 37

Беляева Е.Ю. Актуальный подход к рассмотрению инноваций в инвестиционностроительном комплексе России

Кетова Н.П., Овчинников В.Н. Функционирование этнорынков в экономике регионов Юга России

\section{ФИНАНСЫ, ДЕНЕЖНОЕ ОБРАЩЕНИЕ И КРЕДИТ}

Подкопаева Е.В. Системные проблемы на пути повышения эффективности последующего внутреннего государственного финансового контроля 55

Ливенский В.М. Дедолларизация мировой экономики как фактор противодействия агрессивной политике США

Янов В.В., Иноземцева Е.Ю. Секьюритизация банковских активов: инновационные финансовые инструменты на рынке ипотеки 

социология

\section{ТЕОРИЯ, МЕТОДОЛОГИЯ И ИСТОРИЯ СОЦИОЛОГИИ}





\title{
ВОСТРЕБОВАННОСТЬ МЕТОДОЛОГИИ СОЦИАЛЬНОГО ПОЗНАНИЯ
}

\author{
(c) 2018 Мостовая Ирина Владимировна
}

доктор социологических наук, профессор, главный научный сотрудник Высшей школы бизнеса

Южный федеральный университет

344019, г. Ростов-на-Дону, ул. 23-я линия, д. 43

E-mail: mostovaya@sfedu.ru

Статья посвящена анализу востребованности методологического поиска при исследовании изменений социальной реальности. Рассматриваются взаимосвязи идентичности и маргинальности, семантической трансляции культурного кода в процессе генерационных сдвигов, тектоники изменений в образе жизни под влиянием технологической революции.

Ключевые слова: методология социологии, общество, социальная идентичность, культура, образ жизни.

Наверное, каждому поколению в современном обществе кажется, что оно живет в «эпоху перемен». И социальные философы стараются осмыслить изменения, рассуждают о них, делятся своими наблюдениями и выводами. Социологи, напротив, спешат сделать столь нужные для экономической практики и общественного управления замеры, но не всегда их глубоко и тщательно обрабатывают, анализируют, публикуют. Даже если это получается (как правило, в продолжительных коллективных исследованиях крупных проблем), результаты описываются специальным научным языком, иногда непостижимым не только для междисциплинарного научного оборота, но и для представителей других методологических платформ социологии, хоть в этом и не принято признаваться. В любом случае, выводы социологов проникают в социальный дискурс и практики отрывочно, фрагментарно, а эпистемология социального познания не очень заметно влияет на социологическую эвристику.

Влияние современной российской социологии на общественное сознание также не очень велико, в нем расплавлены некие туманные (но как бы ясные и строгие по содержанию, опорные для вынесения суждений, при этом бесконечно далекие от критерия «лумановской границы») понятия: традиционные ценности, глубокое социальное расслоение, модернизация, общественный договор, наши люди, гражданское общество, маргиналы. Этот замечательный «инструментарий» для описания, объяснения и прогнозирования изменений социальной реальности сам по себе довольно скуден, да и не отражает важных взаимосвязей между состояниями и действиями. И причина, как ни странно, в методологии - ведь именно она определяет принципы познания, порождает системные теоретические подходы и языки описания, в терминах которых заключены «связные» (глубинные, соединяющие понятия и явления друг с другом) [1] социальные смыслы.

Потребность в развитии методологии социального познания, пусть неотчетливо выраженная и робко себя проявляющая - достаточно просмотреть результаты поиска по профильным издательствам, журналам, исследовательским институтам - уже давно не кабинетная, стремящаяся соединить в своей научной потребности запрос как на гносеологию, так и на алгоритм, вполне обоснована теми тектоническими движениями, которые определяют актуальные тренды развития общества.

В обоснование этого тезиса так и тянет пойти с конца: от ситуативных событий к фундаментальным основаниям социальной динамики и собственно теории. Совсем недавно предметом весьма возбужденного общественного обсуждения стала граница пенсионного возраста россиян. Высказались политики, законодатели, эксперты, сообщества работодателей, профсоюзы; гражданские активисты организовали протестные шествия и митинги; решение о повышении пенсионного возраста было принято. Социологи многократно замеряли отношение россиян к проблеме в разрезе регионов проживания респондентов, возрастных, гендерных и профессиональных групп, выявляли несогласие, отрицание, депривацию. Эксперты-экономисты в зависимости от общего подхода обосновывали либо фундаментальную необходимость повышения пенсионного возраста, либо, напротив, 
возможность избежать этого, ссылаясь как на демографические тренды, так и на бюджетный профицит и наполнение общественных фондов, способных поддерживать бездефицитность ПФР. Однако в общественном дискурсе отсутствовали смысловые единицы, позволяющие глубоко и рационально говорить о социальной защите старости, трудовых правах граждан и обязанностях государства, принципах делегирования свободы гражданина в определении своих жизненных перспектив и накапливаемых материальных ресурсов в старшем возрасте, принципов построения пенсионной системы и технологий решения проблем пенсионирования, способах достижения целей в экономике пенсионного обеспечения.

Социологи не стали заметны ни в прояснении смысла и сути общественного договора, ни даже в обосновании того простого следствия повышения возраста выхода на пенсию для женщин, которое приведет к разрушению опорного социального института, «естественным» (габитуализированным) порядком замещавшего важные направления социальной работы в обществе. Конечно, я имею в виду участие в воспитании внуков и помощь престарелым родителям. Мы наблюдаем развитие социального бизнеса и государственных сервисов дополнительного образования детей, патроната пожилых людей и т.п., однако не можем не предполагать, опираясь на экспертные оценки, некоторого обвала в этих двух плоскостях полезной социальной активности «молодых пенсионерок», которые и так всю жизнь несут второе и третье бремя домоводства и воспитания детей помимо труда в общественном производстве. До общественного сознания докричались только социальные демографы, апеллирующие к продолжительности жизни мужчин и куцему периоду пенсионного дожития.

Чтобы правильно выступить в общественной дискуссии, мало сформулировать позицию, надо ее обосновать. А наши исследования структуры обыденной жизни как будто табуированы или же выхолощены их теоретические платформы: не описаны бюджеты времени (разве что только для отдельных групп молодежи), гендерные роли, социальные функции активного населения, трудовые этосы, субкультуры (кроме ювенально девиантных), реальные социальные сети (в которые включены люди, обменивающиеся деятельностью, а не только информацией через интернет).

А молодежь, которая неожиданно стала проявлять некие протестные порывы? Аполитичная и конформная, гиперпатерналистичная и социально инертная [2], она предстала как акционистски мерцающий фантом, заряженный неизвестной энергией и страшащий непросчитанным потенциалом активности и неизвестностью вектора. Очень мало социологических исследований общественных генераций [3], в которых мы находим отчетливые установки поиска методологии изучения общественной транзиции в поколениях.

Еще один актуальный пласт социологических исследований, с очень проблемным уровнем теоретизирования и методологического обоснования - национальные и религиозные общности в современном гражданском обществе, их культурные границы, взаимодействия, взаимопроникновения и конфликтный потенциал. На текущем этапе трудно даже представить спокойную, глубокую, неполитизированную проработку этой предметной области на добротной теоретико-методологической основе, а между тем ее научная и практическая ценность в современном российском обществе беспримерно велика. Сложность состоит отнюдь не в квалификации исследователей, а в эмоционально неровном, насыщенном разнообразными стигматизаторами общественном дискурсе, который неизбежно влияет и на рациональность анализа, и на общественную презентацию научных результатов.

Не вследствие, но рядом и связно стоит проблематика «места России в мире», которая, помимо политических позиций западничества, условного почвенничества и выбора особого пути - опирается в социологии на теории глобализации и нации (национального государства), а описывается в терминологии стратегий общественного развития. Ее полуинструментальным приложением является теория модернизации и наличия/возможности моделей общественного заимствования, которые все глуше обсуждаются в специальной литературе, хотя мы не находим в ней и теоретико-методологических обоснований культурного, социального изоляционизма либо экономической автаркии. Но то, что на макроэкономическом языке именуется «встраиванием в технологические цепочки международного разделения труда» на социологическом языке не формулируется и исследователь не 
озадачен ни простыми, ни многослойными размышлениями о человеке в модернизированном обществе и современном мире.

А между тем этот мир становится все более экономически, технологически, культурно и коммуникативно связным и в силу порядка величин довлеющим на ход определенных социальных активностей и общественных динамик национального уровня. Мы имеем в виду не только формирующиеся тренды больших процессов, мощно втягивающих в свою «орбиту» динамические элементы национально-хозяйственных систем (международные рынки, международные экономические специализации, международную финансовую инфраструктуру, крупные торговые и таможенные союзы и т.п.), но и постоянно развивающуюся сеть надгосударственных институтов, обладающих самостоятельным влиянием системного характера,- а также собственно культурный процесс в его аксиологическом и семантическом аспектах, вовлекающий современного человека в определенную систему ценностных координат, способы и языки информационного обмена.

Переходя от констатации того, что мы живем в быстро развивающемся мире, в котором происходит уже вторая на жизни текущего поколения информационная революция, а биотехнологии, прикладная генетика, роботизация, искусственный интеллект и многие другие векторы научно-технического развития уже прямо влияют на формирование структуры, связей и динамику современного общества, к более частным и «простым» вопросам: например, о взаимодействии активных поколений - мы сразу обнаруживаем, что внутри национального общества резко дифференцирована включенность в глобальный процесс в генерационном, профессиональном, поселенческом срезе. И что бы мы ни взяли: голосование по Брекзиту или наше собственное отношение к пенсионной реформе - мы находим новые и часто неожиданные ареалы солидарностей, которые ставят свой теоретико-методологический вопрос.

Тут мы подходим к более фундаментальным социологическим конструкциям, частным воплощением которых являются электоральные предпочтения и политическая активность, экономическое поведение, духовная общность и готовность на ее основе действовать сообща, или, по крайней мере, сходным образом (частным проявлением чего ныне нередко выступает флешмоб). А именно, неизбежно начинаем размышлять о социальной идентичности и о том, какие она порождает статусы, объединения и поведение.

Из общей социологической теории следует, что нестабильные (динамичные) периоды развития общества порождают дисфункцию социальных институтов, когда они частично разрушаются и структурно-функционально трансформируются, при этом общественные установления (правила, практики, привычки и нормальности в общепринятом смысле) а также ценности, в первую очередь, порядка (должного) нарушаются и ставятся под сомнение участниками общественных отношений. Вместе с объективными границами порядка, в который общество вкладывает огромный объем ресурсов - от материальных до организационных профессионально-квалификационных - становятся субъективно зыбкими границы причисления человека к группам и обществу в целом. А это, как последовательно рассуждает любой социолог, порождает маргинальность.

Мы наблюдаем признаки социальной маргинальности и маргинализации во многих общественных явлениях и процессах, это, в общем-то, обычное явление в живой ткани общества, если не переходит здоровых границ. Внедрение технологий, появление инноваций, изменение потребностей, личный выбор - эти и другие причины могут сдвинуть субъекта на периферию системно-сетевых связей, проявляться в выталкивании или самоотчуждении, стремлении покинуть общность и найти свой новый круг.

Идентичность в социальном плане редко претерпевает «крушение», но расщепление идентичности между разными планами причисления/принятия/отнесения каждый раз порождает маргинальные состояния, как и институциональный кризис, разрушающий социальную позицию и требующий адаптации человека через посредство смены идентичности. Мы всегда говорим о том, что социальная идентичность субъективно проявляется в причислении человеком себя к некой общности (маленькой или большой, от брака до гражданства или религиозного самоопределения). Это необходимое, но не достаточное условие. Сообщество тоже должно счесть человека своим членом, принять его и поддерживать, подтверждать его групповую идентичность. Если между этими двумя условиями происходит разрыв, полный или частич- 
ный, - наступление маргинальных состояний (как, к примеру, у представителей русского мира за рубежом) практически неизбежно: либо человек себя к группе уже не причисляет, а группа считает его своим и репрессирует инструментами стимулирования и нормативного контроля, либо человек себя с данной группой идентифицирует, а она слабо подтверждает его причисление и реальное принятие, вовлечение.

Методологическая эвристика учета этой закономерности представляется очевидной в анализе молодежи, трудовых отношений, даже гражданства.

Расщеп идентичности в социальном смысле возможен и на другом уровне, где ингрупповое причисление может не подтверждаться признанием группового членства человека аутгруппой - то есть людьми, которые сами в эту общность не входят, но считают некоторых людей членами данной группы. Ну, и поскольку уровней причисления три, возможны комбинации расщеплений идентичности, порождающие маргинальные состояния разного характера. $\mathrm{K}$ сожалению, теоретические возможности исследовать разнообразные социальные состояния, выявляя и объясняя их через идентификационные комплексы, не часто используются.

И в заключение хотелось бы заметить, что, несмотря на то, что современная социология очень «культурологична», и это совершенно справедливо, если верить Р. Докинзу, который сформулировал идею о постгенетической эволюции человека на основе трансляции культурных кодов, мы все еще ожидаем фундаментальные социологические работы, описывающие и объясняющие реальность с позиций социального культурогенеза. Будем надеяться, что они вскоре появятся и помогут найти социально значимые ответы.

\section{Библиографический список}

1. См.: Куликов С.Б. Основы философского анализа науки: методология, смысл и цель. Томск, 2005; Ушаков Е.В. Философия и методология науки. Москва. 2017.

2. См., напр.: Горшков М.К., Шереги Ф.Э. Молодежь России: социологический портрет. Москва. 2010; Новое поколение. Всероссийское репрезентативное исследование молодежи 16-26 лет. ФОМ. Москва. 2009; Контрреволюция молодежи: от чрезмерный амбиций к прагматизму. Москва. 2007; Поколение XXI: структура и среды достижительных технологий. Москва. 2008 и др.

3. См., напр.: Герасимов Г.И. Трансформация образования - социокультурный потенциал развития российского общества / Отв. ред. Ю.Г. Волков. Москва. 2005; Луков В.А. Концептуализация молодежи в XXI веке: новые идеи и подходы // Социологические исследования. 2012. № 1. 


\title{
ПРОБЛЕМАТИКА СОБЫТИЙНОСТИ ДЕТСТВА В ЗАРУБЕЖНЫХ ЖУРНАЛАХ *
}

\author{
(c) 2018 Митрофанова Светлана Юрьевна \\ кандидат социологических наук, доцент кафедры социологии и культурологии \\ Самарский национальный исследовательский университет им. Академика С.П. Королева \\ 443086, г. Самара, ул. Московское шоссе, д. 34 \\ E-mail:mit_s@mail.ru
}

В статье поднимается тема событийности детства. На примере аннотаций и названий статей трех зарубежных журналов по детству: «Детство: глобальный журнал исследований ребенка», «Глобальные исследования детства», «География детей» - доказывается, что в современном обществе происходят сдвиги в «нормативных» образах детства, представлениях о событийности детства, обосновывается идея многовекторности и множественности моделей детско-взрослых отношений и взросления детей.

Ключевые слова: событийность детства, зарубежные журналы по детству

Детство отличается постоянной ориентацией на взрослый мир. События жизни ребенка закладывают фундамент развития его личности, оказывают серьезное влияние на дальнейшую жизнь. По этой логике, в условиях, когда взрослая культура защищает границы детства, событийность последнего должна выстраиваться с учетом постепенного и поэтапного освоения социальности, ориентирующей на сообщество взрослых. Однако, ряд авторов говорят о трансформации социальности в глобализирующемся мире, ее ограничении, сокращении, о том, что взрослая культура в современном обществе перестает держать границы детства, о наступившем кризисе детства, понимая последний как кризис событийности детско-родительских отношений [например, 1]. На примере статей зарубежных журналов, содержащих данные авторских эмпирических исследований детей, обозначим, как в них вписана проблематика событийности детства, и дадим ответ на вопрос о том, подкрепляют ли результаты этих исследований по событийности детства идею однонаправленность взросления, или указывают на многовекторность и множественность моделей детско-взрослых отношений и взросления детей.

Данный вопрос рассмотрим на основе обращения исследовательского внимания к названию и аннотациям статей таких зарубежных журналов по детству, как «Детство: глобальный журнал исследований ребенка» (Childhood. A journal of global child research) и «Глобальные исследования детства» (Global Studies of Childhood) издательства Sagepub, «География детей» (Children's Geographies) издательства Routledge. Выбор данных журналов обусловлен тем, что в них содержится достаточно широкий, междисциплинарный взгляд на детство в отличие от журналов более узкой направленности, например, с такими названиями как: «Современные вопросы раннего детства» (Contemporary Issues in Early Childhood), «Нетипичные дети», (Exceptional Children), «Журнал одаренного ребенка» (Gifted Child Quarterly) и другие. Интерес к выше обозначенным журналам также обусловлен наличием в открытом доступе всех аннотаций и даже отдельных полных текстов статей.

Вопросы событийности детства так или иначе вписаны в такие проблематики исследований зарубежных авторов, как: изучение транзиции от детства к зрелости, концепта заботы в отношениях между родителями и детьми, выстраивания ребенком своей идентичности через трудовую деятельность, гендерных измерений тех или иных аспектов жизни детей и т.д.

Отметим, что проведенный нами анализ событийности детства [например, 2; 3] свидетельствует о том, что взрослая культура в современном обществе перестает держать границы детства, и само понятие детства (как и других концептов, связанных с взрослением человека) становится более расплывчатым, прерывистым,

\footnotetext{
* Статья, написана при поддержке гранта РГНФ (грант № 16-06-00792а, Детство в социогуманитарной перспективе: тезаурус 2016-2018).

This article was prepared with the support of the Russian Humanitarian Scientific Fund (grant No. 16-06-00792a, Childhood in the socio-humanistic perspective: the thesaurus 2016-2018).
} 
нечетким, аморфным. На наш взгляд, этот тезис подтверждают и результаты исследований проведенных зарубежными авторами отдельных событий жизни детей, таких как переживание детьми развода родителей, трудовая деятельность, употребление алкоголя и другие.

Анализ переживания детьми развода родителей связан с трактовкой концепта «заботы» в детско-родительских отношениях. Его традиционное толкование основано на том, что родители дают заботу детям, а дети получают ее от них. Однако, как указывает Anja Marschall, на основе исследования повседневной жизни датских детей 8-12 лет и их родителей после развода, забота - это не однонаправленный, а взаимный процесс поддержки и ухода детей и родителей друг за другом [4].

О неоднозначности интерпретаций событий детства, размывании его содержания, свидетельствуют исследования детского труда, зависимости последнего от социально-экономического класса, к которому принадлежат родители детей, территории их проживания, занятости родителей и ряда других факторов. Так, Géraldine André и Marie Godin указывают на различные трактовки детского труда, связанного с добычей полезных ископаемых в Демократической Республике Конго (ДРК). В ДРК в течение последних трех десятилетий расширяется развитие кустарной и мелкомасштабной горнодобывающей промышленности, в результате чего в этот процветающий деловой сектор приходит все больше городских семей, в том числе детей. Авторы подчеркивают, что в соответствии с международным законодательством о правах ребенка этот вид занятости детей относится к одной из наихудших форм детского труда. Показано, что для семей из среднего класса этот вид работы зачастую является социально деструктивным, находящимся в авангарде межпоколенческого конфликта. Что касается семей из низших классов, то социальные изменения, вызванные деятельностью детей в горнодобывающей промышленности, лучше вписаны в их габитус [5].

Enoch Tawiah Sackey и Berit Overå Johannesen исследуют значения, которые дети, вовлеченные в рыболовство и фермерство в двух общинах г. Кейп-Кост (Гана, Африка), придают своему участию в работе и школе. Авторы отмечают, что дети рассказывают о том, как они выстраивают свою идентичность, приобретают уважение и компетентность через работу, описывая соб- ственные усилия как воспроизводство традиционного межпоколенческого порядка с сильными нравственными коннотациями. Но вместе с тем, в будущем многие из них мечтают о других видах занятости [6]. Таким образом, практики вовлечения в трудовую деятельность детей как компонент событийности их детства находят различное отражение как в собственных пониманиях детьми значений этой деятельности, так и трактовках их родителей.

Первая проба алкоголя - один из компонентов событийности детства. Clare Holdsworth, Louise Laverty и Jude Robinson рассматривают гендерные различия в алкогольном поведении мальчиков и девочек 13-14 лет в контексте пространства в Ливерпуле, Великобритания [7]. Ученые исследуют, как использование пространства было связано с экспериментами с алкоголем, каков гендерный аспект опыта употребления алкоголя. Gill Valentine, Mark Jayne и Myles Gould отмечают, что средний возраст начала употребления спиртных напитков в Европе сегодня - 12 лет. Авторы проводят эмпирическое исследование роли алкоголя в семейной жизни Великобритании, изучая, в частности, информированность детей об алкоголе, их понимание рисков для здоровья, связанных с употреблением алкоголя [8].

Приобретение способности нести ответственность по уходу за домашним животным также можно рассматривать как важный компонент событийности детства. Janine C. Muldoon, Joanne M. Williams, Alistair Lawrence отмечают, что отношения с конкретными животными часто рассматриваются как «мостик» к заботе об окружающей среде в целом. Авторы статьи методом фокус-группы с детьми в возрасте от 7 до 13 лет изучили их деятельность, формирование чувства ответственности в процессе ухода за домашними животными, влияние на детей родительских ролей и ограничений, связанных с заботой детей о своих питомцах [9].

Сексуальность детей также можно рассматривать с точки зрения компонентов событийности детства. Проблематике детской сексуальности посвящены статьи Ingrid Voléry и Deevia Bhana. Ingrid Voléry концентрируется на исследовании форм сексуализации детей, построенных французскими властями в период с 2000 по 2013 год [10]. Deevia Bhana анализирует, как южноафриканские индийские подростки - мальчики и девочки концептуализируют желание, секс и 
любовь. В статье обращается внимание на переосмысление детства, распространение детской активности за пределы озабоченности сексуальной опасностью. Фокусируясь на разнообразии сексуальных значений, внимание уделяется множественности детского сексуального опыта среди южноафриканских индийских подростков. В статье утверждается, что более глубокое понимание подросткового удовольствия и власти может заострить внимание на интервенциях, способствующих здоровой подростковой сексуальности [11]. Данные представленных исследований свидетельствуют о наличии различных режимов детской сексуальности как способов организации последней. Определенные режимы конструируются как внешними структурами (территория проживания, традиции, законодательство, принадлежность к социально-экономическому классу, этнической группе и т.д.), так и воссоздаются сексуальными практиками самих детей.

Образование выступает важным элементом событийности детства, этой тематике посвящены статьи Lydia Marshall [12], Maria Hatzigianni [13]. Обсуждаются вопросы значения образования для детей, использования информационных технологий на разных ступенях образовательного процесса, в том числе и дошкольного. Сам доступ детей к цифровым технологиям также является важным компонентом событийности детства [14].

Организованный досуг выступает компонентом событийности детства. Susanne Nordbakke исследовала досуг вне дома детей 6-12 лет в
2005 и 2013-2014 годах в Норвегии. Автор отмечает, что доля детей, участвующих в организованном досуге, увеличилась, что они начинают участвовать в нем в более раннем возрасте и что интенсивность участия в организованном досуге возросла [15].

О трансформации семейной социализации ребенка свидетельствуют результаты проведенного Anna Malmquist, Anna Möllerstrand, Maria Wikström, Karin Zetterqvist Nelson исследования детей в семьях лесбиянок: представлений детей об идентичности их родителей [16].

Отметим специфику публикаций журнала Childhood, в нем огромное внимание уделяется исследованию «нетипичных» детей. Так, в качестве объектов эмпирических исследований выступают дети с ограниченными возможностями, в том числе умственными. Исследуется, в частности, специфика участвующих исследований с ними, в том числе тех, что посвящены проблематике сексуальности, их праву на образование и т.Д.. Дети мигрантов, дети в странах третьего мира, дети в семьях с низким уровнем доходов, дети этнических меньшинств (например, цыгане) и другие подобные категории детей выступают объектом исследовательского интереса.

Таким образом, исследовательский фокус на обозначенных проблематике и категориях исследуемых детей указывают на сдвиги в «нормативных» образах детства и представлениях о событийности детства, что также подтверждают результаты исследований отечественных авторов, упомянутых в данной статье.

\section{Библиографический список}

1. Эльконин Б.Д. Кризис детства и основания проектирования форм детского развития [Электронный ресурс] // Вопросы психологии. 1992. № 3. C.7-13. http://www.voppsy.ru/issues/1992/923/923007.htm (дата обращения: 1 октября 2018)

2. Майорова-Щеглова С.Н. Влияние событийности детства поколения Z на социопсихологические проблемы студенческой жизни: реперные точки психологической службы вуза / Психологическая служба университета: реальность и перспективы. Материалы I Всероссийской научно-практической конференции с международным участием. 2017. С. 266-271.

3. Митрофанова С.Ю. Маркеры «взрослости» и события детства / Географии детства: междисциплинарный синтез исследовательских подходов и практик. Материалы международной молодежной научной школы-конференции. Ответственный редактор А.Г. Филипова. 2018. С. 159-162.

4. Marschall A. Who cares for whom? Revisiting the concept of care in the everyday life of post-divorce families // Childhood. 2014. Vol.21. Is.4. Pp. 517-531.

5. André G., Godin M. Child labour, agency and family dynamics. The case of mining in Katanga (DRC) // Childhood. 2014. Vol.21. Is.2. Pp. 161-174.

6. Sackey E. T., Johannesen B.O. Earning identity and respect through work: A study of children involved in fishing and farming practices in Cape Coast, Ghana // Childhood. 2015. Vol.22. Is.4. Pp. 119-133. 
7. Holdsworth C., Laverty L., Robinson J. Gender differences in teenage alcohol consumption and spatial practices // Children's Geographies. 2017. Vol. 15. Is. 6. Pp.741-753.

8. Gill V., Jayne M., Gould M. The proximity effect: The role of the affective space of family life in shaping children's knowledge about alcohol and its social and health implications // Childhood. 2014. Vol.21. Is.2. Pp. 103-118.

9. Muldoon J. C., Williams J.M., Lawrence A. «Mum cleaned it and I just played with it»: Children's perceptions of their roles and responsibilities in the care of family pets // Childhood. 2015. Vol.22. Is.2. Pp. 201-216.

10. Voléry I. Sexualisation and the transition from childhood to adulthood in France: From age-related child development control to the construction of civilisational divides // Childhood. 2016. Vol.23. Is.1. Pp. 143-153.

11. Bhana D. Sex isn't better than love': Exploring South African Indian teenage male and female desires beyond danger // Childhood. 2016. Vol.23. Is.3. Pp. 362-377.

12. Marshall L. 'Going to school to become good people': Examining aspirations to respectability and goodness among schoolchildren in urban Ethiopia // Childhood. 2016 Vol.23. Is.3. Pp. 423-437.

13. Hatzigianni M. Transforming early childhood experiences with digital technologies // Global Studies of Childhood. 2018. Vol.8. Is.2. Pp. 173-183/

14. Dias P., Brito R., Ribbens W. The role of parents in the engagement of young children with digital technologies: Exploring tensions between rights of access and protection, from 'Gatekeepers' to 'Scaffolders' // Global Studies of Childhood. 2016. Vol.6. Is.4. Pp. 414-427.

15. Nordbakke S. Children's out-of-home leisure activities: changes during the last decade in Norway // Children's Geographies. 2018 https://twitter.com/childrensgeogs (дата обращения: 1 октября 2018).

16. Malmquist A., Möllerstrand A., Wikström M., Nelson K.Z. A daddy is the same as a mummy: Swedish children in lesbian households talk about fathers and donors // Childhood. 2014. Vol.21. Is.1. Pp. 119-133.

Поступила в редакцию 09.10.2018 
социология

\section{СОЦИАЛЬНАЯ СТРУКТУРА, СОЦИАЛЬНЫЕ ИНСТИТУТЫ И ПРОЦЕССЫ}





\title{
КОНКУРЕНТОСПОСОБНОСТЬ ЖЕНЩИН НА РЫНКЕ ТРУДА В СВЕТЕ ГЛОБАЛЬНЫХ ТРЕНДОВ
}

\author{
() 2018 Соболева Ирина Викторовна \\ доктор экономических наук, главный научный сотрудник \\ Институт экономики Российской академии наук \\ 117218, г. Москва, Нахимовский пр., д. 32 \\ E-mail: irasobol@gmail.com
}

В статье рассматриваются факторы и тенденции изменения конкурентоспособности женщин в современной экономике. На основе данных международных исследований показано, что сегодня главные факторы снижающие относительную конкурентоспособность женщин по сравнению с мужчинами связаны не с качеством женской рабочей силы, а с гендерными стереотипами, которые запускают механизмы гендерной дискриминации, тормозящие реализацию человеческого потенциала женщин в сфере занятости.

Ключевые слова: конкурентоспособность женщин, рынок труда, гендерный разрыв, индекс гендерного неравенства, гендерная дискриминация

Существует ряд категорий рабочей силы, которые традиционно считаются обладателями относительно низкой конкурентоспособности на рынке труда. К ним относятся лица старших возрастов, молодежь, впервые выходящая на рынок труда, трудовые мигранты и представители некоренного населения той или иной страны. К этой группе относятся и женщины, как правило, уступающие работникам-мужчинам по ряду основных индикаторов конкурентоспособности.

Индикаторами конкурентоспособности работников могут служить 1) показатели качества рабочей силы, прежде всего образовательные и профессионально-квалификационные характеристики, показатели состояния здоровья, характеризующие индивидуальный человеческий (экономический) потенциал 2) показатели, характеризующие их положение в сфере занятости, т.е. масштабы и успешность фактической реализации этого потенциала в сфере труда. Ко второй группе относятся уровень экономической активности, занятости и безработицы сопоставляемых категорий работников, размер заработной платы, статус рабочего места, режим и условия труда, объем предоставленных работодателем социальных гарантий. На протяжении длительного исторического периода практически во всех странах мира женщины уступали мужчинам по большинству показателей обеих групп. Однако в последние несколько десятилетий прослеживается тенденция к росту человеческого потенциала женщин и к сокращению на этой основе гендерного разрыва.

Для оценки гендерного разрыва в социально-политических и экономических возможностях мужчин и женщин Всемирный экономический форум сконструировал и ежегодно рассчитывает специальный индекс, сопоставляющий ресурсы и реализованные возможности мужчин и женщин в 135 странах мира. Данный индекс фиксирует гендерный разрыв на основе 14 субиндексов, отражающих четыре аспекта. Два из них - образование и здоровье, сопоставляют параметры человеческого потенциала женщин и мужчин. Два других аспекта - экономические возможности и политические права измеряют успешность его фактической реализации. Человеческий потенциал в аспекте образования, оценивается по таким критериям, как грамотность населения, наличие и доступность образования различного уровня. Индекс здоровья и выживания строится на основе данных о продолжительности жизни мужчин и женщин и о соотношении полов при рождении.

При построении индекса гендерного неравенства в области экономической активности и экономических возможностей, учитываются такие параметры как уровень экономической активности, возможности доступа к престижным и хорошо оплачиваемым рабочим местам, а также соотношение заработных плат. В сфере политического права, индекс отражает долю представительства женщин в органах законодательной и исполнительной власти. Отчет по состоянию гендерного неравенства издается Всемирным экономическим форумом с 2006 г., но по ряду 
стран соответствующая информация собирается, уже начиная с 2000 г.

На протяжении двух десятилетий статус наиболее равноправных в гендерном отношении прочно удерживают страны северной Европы. Исландия, Финляндия, Норвегия и Швеция в период с 2000 по 2016 год делят между собой 4 первых места в списке. Заметим, что индексы лидирующих стран при итоговом подсчете увеличиваются в основном благодаря образовательному аспекту и высокому представительству женщин в структуре власти. Именно этим в немалой степени объясняется высокий рейтинг Филиппин: это одна из немногих стран мира, где доля женщин среди законодателей, высших чиновников и топ-менеджеров превышает долю мужчин. Наиболее ощутимый гендерный разрыв характерен для арабских стран: Саудовская Аравия. Россия занимает относительно устойчивое положение внизу верхней половины рейтинга, что свидетельствует о том, что у российских женщин, в сравнении с мужчинами, доступ к различным ресурсам ограничен, но не критичен.

Несмотря на общемировой тренд к сокращению гендерного разрыва, в ряде стран этот показатель вырос. Характерно, что в основном это восточноевропейские трансформационные экономики. Так, гендерный разрыв увеличили Хорватия, «упавшая» с 16 места до 49, Эстония с 29 места опустившаяся до 60, а также Македония, переместившаяся с 28 на 61 место. Несмотря на уменьшившуюся разницу в оплате труда мужчин и женщин, в Македонии показатель ухудшился за счет уменьшения политической активности женщин и крайне низкого субиндекса «здоровье и выживание» [1].

Среднемировые значения субиндексов образования и здоровья приближаются к единице, а во многих странах, к числу которых относится и Россия, разрыв по этим параметрам практически ликвидирован. Многие страны добились не только равенства в доступе к образованию, но и относительно более высоких показателей для женщин. Женский показатель уровня грамотности выше, чем у мужчин в 12 странах. Среди них преобладают страны Южной Америки и Африки. В развитых странах, где население практически поголовно грамотно, отрыв женщин по этому параметру невозможен. Однако многие из них демонстрируют более высокий по сравнению с мужчинами охват женщин высшим образованием. В Норвегии, Швеции и Исландии в высших учебных заведениях обучаются более $90 \%$ женщин соответствующего возраста, но лишь около половины мужчин. В Финляндии и Дании женщины также составляют большинство учащихся в высших учебных заведениях. Однако наибольший разрыв в пользу женщин по этому показателю демонстрирует Катар, где охват образованием женщин более чем в пять раз превышает охват мужчин. На Барбадосе женщины получают высшее образование примерно втрое чаще, чем мужчины.

При рассмотрении различных аспектов гендерного разрыва можно заметить, что отставание женщин от мужчин в том, что касается развития человеческого потенциала, преодолевается значительно активней, чем, когда речь идет о его реализации на рынке труда. Практически во всех странах мира женщины значительно менее успешны по сравнению с мужчинами. Это касается и уровня экономической активности женщин, и доступности для них хороших рабочих мест, и уровня оплаты труда. Следует отметить, что ряд сравнительно бедных стран с устойчиво низкими показателями экономической активности, занятости и оплаты труда (Монголия, Багамы, Бурунди) демонстрируют минимальный гендерный разрыв в области экономических возможностей. Иными словами, наивысшая степень гендерного равенства достигается в беднейших странах, где возможности эффективной экономической реализации человеческого потенциала крайне низки, как для мужчин, так и для женщин.

На иной основе достигается сближение экономических возможностей мужчин и женщин в странах Северной Европы, отличающихся высоким уровнем экономической активности и трудовых доходов большинства населения при минимальной разнице в параметрах занятости и оплаты труда по признаку пола. В этих странах созданы условия для того что бы в семье имели возможность работать оба родителя. Государство разработало гендерно нейтральную систему социальных гарантий, направленных на поддержку семьи, включающие единовременные выплаты при рождении ребенка, детские пособия, налоговые льготы для работодателей, у которых на производстве заняты работники с детьми, специальные программы поддержки материнства. Среди европейских стран самый высокий рейтинг преодоления гендерного разрыва имеют Норвегия и Люксембург. Россия по 
данному параметру занимает 39 место.

Таким образом «узким местом» на сегодняшний день является не недостаточное развитие человеческого потенциала женщин, а ограниченные возможности для его реализации. Данный вывод ВЭФ подтверждают результаты другого авторитетного международного исследования Программы развития ООН, в рамках которой разработана система индексов развития человеческого потенциала и ежегодно публикуются доклады, сопоставляющие параметры человеческого развития в различных странах мира. На протяжении нескольких лет в систему индексов развития человеческого потенциала ПРООН в качестве экспериментальной составляющей входит индекс гендерного неравенства. Страны-лидеры в области человеческого развития и в области преодоления гендерного разрыва отнюдь не всегда совпадают. Так, США, получившие в 2013 г. третий рейтинг по главному индексу развития человеческого потенциала, несмотря на всю риторику равноправия и продвижения женщин, по индексу гендерного неравенства занимают лишь 42 место. При этом наибольший вклад в гендерный разрыв вносят показатели участия в рабочей силе. Наибольший разрыв в пользу мужчин наблюдается в Арабском мире [2].

Данные международных исследований свидетельствуют также о том, что наращивание образовательного капитала далеко не всегда расширяет экономические возможности женщин. Неустойчивость положения женщин на рынке труда отражает их относительно низкий по сравнению с мужчинами уровень экономической активности. Эксперты Международной организации труда отмечают, что женщины в сравнении с мужчинами чаще заключают временные трудовые отношения, а также с тем, что женщина вынуждена прерывать свою карьеру ради воспитания детей. Во многих странах мира уровень женской безработицы превосходит уровень мужской [3]. Даже когда мужчины и женщины выходят на рынок труда, имея сопоставимый уровень квалификации, женщины, как правило, отстают при продвижении по карьерной лестнице. Женский труд преобладает на низших ступенях рынка труда, то есть на низкооплачиваемых, мало производительных работах, в том числе в неформальном секторе экономики [4].

Наиболее явно гендерные различия на рынке труда проявляются в существенном и устой- чивом отставании заработков женщин от заработков мужчин, которое имеет место во всех без исключения странах, даже наиболее эгалитарных. Как показывают данные мониторинга ВЭФ, охватывающего более сотни стран, вне зависимости от уровня экономического развития, заработки женщин всегда ниже чем мужчин. Разрыв составляет от $82 \%$ в Боливии, до всего $15 \%$ в Сирии. И в такой бедной стране как Никарагуа, и в богатом благополучном Люксембурге, и в динамично развивающемся Сингапуре средний заработок женщин составляет примерно половину от заработка мужчин. В известной своими достижениями в области выравнивания возможностей Норвегии женщины зарабатывают менее 80\% от того, что зарабатывают мужчины [5].

Информационный портал «Экономика и общество» осуществил «инвентаризацию» доступной информации о гендерных различиях в оплате труда США - страны, где вопросы достижения гендерного равенства и поддержания «паритета» мужчин и женщин в сфере занятости, являются одним из первых государственных и общественных приоритетов. Отставание заработной платы женщин от заработной платы мужчин составляет от 23\% до 41\% в зависимости от сферы деятельности, а также расовой и этнической принадлежности. По данным Института исследований политик, направленных на женщин (Institute for Women's Policy Research), ведущего сопоставительный мониторинг женских и мужских заработков в США с 1955 г., разрыв заработков женщин и мужчин постепенно сокращается. Однако темпы этого сокращения очень медленные. При их сохранении по подсчетам сотрудников института паритет будет достигнут только к 2058 г. [6]. По данным Американской ассоциация женщин - выпускниц университетов, несмотря на то, что в процессе получения образования, успеваемость у женщин выше и они чаще повышают квалификацию после получения диплома, выпускницы, спустя год после окончания учебного заведения, зарабатывают в среднем на 20\% меньше мужчин. Спустя десять лет с момента выпуска, разница в доходе увеличивается до 31\% и появляется разрыв в должностном статусе. К тому моменту как женщина достигает возраста 65 лет, она зарабатывает, примерно 75\% от того, что зарабатывают мужчины того же возраста [7].

Проведенный анализ свидетельствует о том, что уязвимость женщин на рынке труда сегодня не может быть объяснена низким качеством жен- 
ской рабочей силы. В значительной степени она является следствием гендерной дискриминации, которая может существовать как в открытых, так и в замаскированных формах. Применительно к сфере занятости дискриминация означает, что к отдельным работникам, обладающим одинаковыми характеристиками по признаку производительности, относятся по-разному из-за того, что они представляют разные социально-демографические группы [8]. Можно выделить четыре пласта гендерной дискриминации, снижающие конкурентоспособность женщин на рынке труда. Первый пласт составляют дискриминационные практики вне сферы оплачиваемой занятости, отрицательно влияющие, прежде всего, на внутренние факторы конкурентоспособности женщин, связанные с качеством рабочей силы и с трудовой историей. Второй пласт - дискриминация при найме на работу, в процессе отбора работодателями претендентов на вакантные рабочие места. Третий - дискриминационные практики при должностных перемещениях и увольнениях. И наконец, дискриминационные практики, непосредственно связанные с оплатой труда.

Несмотря на постепенное распространение модернизационных ценностей, к числу которых относятся гендерное равенство и гендерная справедливость, и в обществе, и в исследовательской среде довольно прочные позиции удерживает подход, явно или неявно оправдывающий сохранение устоявшихся гендерных ролей. Его сторонники выстраивают различные системы аргументации, обосновывающие разделение труда между полами, в соответствии с которым естественное предназначение женщин быть хранительницами домашнего очага, а мужчин - кормильцами семьи, за которыми закрепляется роль первого работника. Апелляция к природным особенностям мужчин и женщин по существу представляет собой попытку закрепления в современной социально-экономической реальности дискриминационных практик, сложившихся на протяжении многих веков. Масштабное межстрановое исследование, проведенное в рамках ОЭСР, показало, что не только в странах третьего мира, но и в наиболее развитых экономиках значительная часть мужчин и женщин продолжают считаться с традиционными гендерными ролями. При этом их поведение, связанное с рынком труда, формируется под воздействием усвоенных ими культурных и социальных ценностей, которые как таковые носят дискриминационный характер и определяют те или иные черты образа жизни и трудового поведения как «мужские» или «женские» [9].

Второй пласт дискриминации женщин связан с неравным отношением к мужчинам и женщинам в процессе найма на работу, т.е. это дискриминация на открытом рынке труда. О предвзятом отношении к женщинам в процессе найма свидетельствуют обширные эмпирические данные. Ряд исследований показал, связанных в частности с распространением среди работодателей идентичных фиктивных резюме, подписанных мужскими и женскими именами, показал, что мужское имя существенно повышает шансы быть приглашенным на собеседование. При этом, если взаимосвязь между конкурентоспособностью работников мужчин и их семейным положением, в том числе наличием детей незначима, а иногда даже позитивна, то для женщин это очень серьезный негативный фактор, снижающий шансы получить работу [10].

Здесь следует сразу же заметить, что такого рода дискриминационные практики, к сожалению, основаны не только на стереотипах. Несмотря на то, что во многих странах, включая Россию, на отпуск по уходу за ребенком имеет право любой из родителей, на практике, в подавляющем большинстве случаев такими отпусками пользуются преимущественно женщины. Они же значительно чаще берут бюллетень в связи с болезнью детей. Словом, привлекательность женщин в глазах работодателей в значительной степени снижена в значительной степени именно благодаря реально существующему традиционному распределению гендерных ролей внутри семьи.

Укорененность традиционных гендерных установок лежит и в основе такой специфической формы гендерной дискриминации как горизонтальная сегрегация занятости, т.е. разделение профессий и видов экономической деятельности на «мужские» и «женские», т.е. дискриминация в доступе к определенным нишам рынка труда, как правило, характеризующимся относительно высоким уровнем заработков. Наряду с поиском компромисса между семьей и работой важным фактором, закрепляющим горизонтальную сегрегацию занятости, являются гендерные стереотипы. Во многом именно благодаря стереотипам доминирует тенденция преобладания женщин в тех сферах занятости, 
которые предполагают выполнение «естественных» для женщин функций: воспитания детей, заботы о здоровье и благополучии близких, ухода за теми, кто не может обслуживать себя сам. В результате многие женщины склонны отдавать предпочтение занятости в так называемой «мягкой экономике», т.е. в таких сферах деятельности как образование, здравоохранение, сфера услуг [11]. Таким образом поддерживается неявный социальный контракт, предопределяющий как разные предпочтения работников в отношении тех или иных видов деятельности и разное отношение работодателей в зависимости от того, претендует ли тот или иной соискатель на место в мужском или женском сегменте рынка труда.

Гендерная дискриминация женщин на рынке труда не исчерпывается горизонтальной сегрегацией, обусловливающей концентрацию женского труда в относительно низко оплачиваемых видах деятельности. Не менее важным ее проявлением является вертикальная сегрегация, закрепляющая различия в должностном положении мужчин и женщин. Для объяснения феномена вертикальной сегрегации обычно используется введенная в научный оборот в 80-х годах прошлого века метафора «стеклянного потолка». Она фиксирует тот факт, что, несмотря на юридическое закрепление принципа равных возможностей, на практике существует множество неформальных, «невидимых» барьеров, препятствующих продвижению женщин по ступеням должностной иерархии и не позволяющих им продвинуться выше определенного уровня.

Наконец последний четвертый пласт дискриминации, связан с прямой дискриминацией в оплате труда. Как было показано выше, отставание заработков женщин от заработков мужчин отмечается во всех без исключения странах, где проводились соответствующие замеры. Гендерный разрыв в оплате труда является важнейшим количественным индикатором относительно более низкой конкурентоспособности женщин. Разрыв в оплате труда также может быть следствием разных факторов. Наиболее очевидный из них - меньшая продолжительность рабочего времени. Кроме того, мужчины чаще женщин работают в тяжелых и опасных условиях, что предполагает соответствующую компенсацию, а женщины чаще имеют перерывы в работе и силу различия планки пенсионного возраста раньше заканчивают карьеру.

Следует отметить, что многие из перечисленных факторов, на первый взгляд прямо не связанных с дискриминацией, тем не менее могут являться следствием более широких проявлений дискриминации, лежащих вне сферы занятости.

Таким образом, более слабые позиции женщин на рынке труда, являющееся свидетельством их относительно низкой конкурентоспособности по сравнению с мужчинами, могут представлять собой как следствие дискриминационных практик, имевших или имеющих место вне этой сферы, так и дискриминацию в чистом виде. При этом довольно сложно отделить одно от другого. Укорененность традиционных гендерных ролей образует своеобразный порочный круг: обремененность домашними обязанностями не дает женщинам в достаточной мере реализоваться в профессиональной деятельности, следствием чего является относительно низкая оплата их труда. А она, в свою очередь, служит аргументом для окончательного закрепления их в традиционной социальной роли.

\section{Библиографический список}

1. The Global Gender Gap Report 2017. World Economic Forum. Geneva, 2017 http://www3.weforum.org/docs/WEF_ GGGR_2017.pdf (дата обращения 12.08.2018)

2. Цели развития тысячелетия: доклад за 2015 год. Нью-Йорк. ПРОOH, 2012. URL: http://www.un.org/ru/ millenniumgoals/mdgreport2015.pdf (дата обращения 12.08.2018)

3. ILO. Global Employment Trends for Women: December 2012 / International Labour Office. - Geneva: ILO, 2012.

4. Содействие переходу к формальной экономике на примере некоторых государств - участников СНГ / Под ред. О. Кулаевой и Ф. Лапера.- М.: МОТ. 2014.

5. The Global Gender Gap Report 2017. World Economic Forum. Geneva. 2017 http://www3.weforum.org/docs/WEF_ GGGR_2017.pdf (дата обращения 12.08.2018)

6. Hegewisch A., Williams C., Hartmann H., Hudiburg S. The Gender Wage Gap: 2013. Differences by Race and Ethnicity. No Growth in Real Wages for Women. 2014. URL: https://www.coursehero.com/file/p2nod2i/The-Gender-WageGap-2013-Differences-by-Race-and-Ethnicity-No-Growth-in-Real/ (дата обращения 12.08.2018) 
7. The Simple Truth about the Gender Pay Gap. American Association of University Women Educational Foundation/ Washington, DC. 2018 URL: https://www.aauw.org/aauw_check/pdf_download/show_pdf.php?file=The_Simple_ Truth (дата обращения 12.08.2018)

8. Воронина О.А. Формирование гендерного подхода в социальных науках / Гендерный калейдоскоп. Москва. 2001. C. 4-14.

9. Баскакова М.Е., Мезенщева Е.Б. Гендерное преломление целей развития тысячелетия для России / Народонаселение. 2006. № 1. С. 43-58.

10. Goldin C., Rouse C. Orchestrating Impartiality: The Impact of 'Blind' Auditions on Female Musicians // American Economic Review. 1997. T. 90. № 4. P. 715-742.

11. Esping-Andersen G. Why We Need a New Welfare State. Oxford: Oxford University Press, 2002.

Поступила в редакцию 25.09.2018 
ЭКОНОМИКА. ЭКОНОМИЧЕСКИЕ НАУКИ

\section{ЭКОНОМИЧЕСКАЯ ТЕОРИЯ}





\title{
АГРАРНАЯ ПОЛИТИКА В СТРАНАХ С РАЗВИВАЮЩЕЙСЯ ЭКОНОМИКОЙ: ВЫБОР ИНСТИТУЦИОНАЛЬНОГО НАПРАВЛЕНИЯ
}

\author{
(C) 2018 Осипов Владимир Сергеевич \\ доктор экономических наук \\ Московский государственный институт международных отношений (университет) \\ Министерства иностранных дел Российской Федерации (МГИМО) \\ 119454, г. Москва, проспект Вернадского, 76 \\ E-mail:vs.ossipov@gmail.com
}

В статье предпринята попытка поиска дисфункций в реализации институциональных реформ в агропродовольственном секторе стран с развивающейся экономикой. На основе институционального анализа выявлены два направления институциональных реформ - пигувианское и коузианское,- по именам выдающихся теоретиков институциональной науки (А. Пигу и Р. Коуз). Показано различение этих направлений и возможные направления реализации направлений в аграрной сфере. Выявлена проблема доверия в аграрной экономике. Восстановление доверия показывается как основополагающая проблема в реализации институциональных реформах в аграрном секторе экономики стран с развивающейся экономикой.

Ключевые слова: институциональная реформа, коузианское и пигувианское направление институциональных реформ, доверие, аграрный рынок, инфраструктура.

Шанхайская организация сотрудничества преследует цель обеспечить экономическое развитие стран-участниц. Аграрная политика занимает одно из ведущих мест в обеспечении интенсивных консультаций между странами-участницами ШОС и представляет собой составную часть государственной социально-экономической политики, направленной на устойчивое развитие сельского хозяйства и сельских территорий. Так как аграрная политика - это часть государственной социально-экономической политики, то она должна подчиняться общим принципам формирования последней. Понимание того факта, что аграрная политика выражается в стратегии повышения эффективности аграрного производства, что, в свою очередь, требует обеспечения защиты экономических интересов сельскохозяйственных товаропроизводителей от антиконкурентного поведения зарубежных аграриев, позволяет нам определить институциональные направления реализации аграрной политики. Важно отметить, что для всех стран с развивающейся экономикой наблюдаются сходные проблемы в реализации государственной аграрной политики [11].

Принципы аграрной политики сводятся к последовательности осуществления мер государственной аграрной политики, институционализации и адресности государственной поддержки, формированию цивилизованных рыночных условий на рынке аграрных продуктов, открытости аграрной политики. Основными направлениями аграрной политики следует назвать защиту интересов отечественных сельскохозяйственных товаропроизводителей и формирование институциональных условий устойчивого развития аграрной сферы, что следует из нормативного определения аграрной политики.

Интересы российских сельхозтоваропроизводителей получили особую институциональную поддержку в связи с введением запретительных мер в рамках политики импортозамещения. Новые институты создали новые условия для расширения производства аграрных продуктов

Следует отметить, что основная проблема в системе государственного управления экономическими отношениями раскрывается через дихотомию стремления к упорядоченности и предсказуемости отношений и поведения акторов, и необходимости постоянного развития посредством внесения изменений в отношения и поведение акторов. Выстраивание системы государственного управления подчиняется цели решения указанной дихотомии через поиск баланса разумного консерватизма и необходимого динамизма.

Пигувианское направление экономической политики предусматривает формирование такой системы институтов государственного 
управления, которая вынуждает акторов действовать в соответствии с интересами инициатора института. Инициатор института (государство) в этом случае принимает на себя роль координатора потребностей общества. Коузианское направление, напротив, предлагает решение трех проблем институционализации экономики: развития конкуренции, защиты прав собственности, минимизации трансакционных издержек. Предполагается, что акторы будут самостоятельно действовать эффективно в интересах как инициатора института, так и общества в целом. Важной проблемой остается выбор пути институциональных реформ.

Коузианское направление институциональной реформы оказывается более предпочтительным по сравнению с пигувианским из-за возможностей большей симметрии в распределении информации относительно импортируемого института.

В нашем случае реализация институциональной реформы в аграрной сфере начиналась (в 1992 г.) с формирования и укрепления частной собственности, снижения монополизма для развития конкуренции и минимизации трансакционных издержек, тем не менее, со временем свернула с коузианского направления в пигувианское. Институциональная реформа стала преследовать цель формирования такого хозяйственного механизма, который был бы наиболее податлив к политическому влиянию. Политическая целесообразность стала диктовать направление экономического развития, а значит и руководящие указания системы государственного управления были переориентированы не на триединые коузианские условия, а на пигувианскую подверженность политическим решениям.

Методология исторического институционализма позволяет нам оценить повторяемость процессов монополизации в сельском хозяйстве. А.В. Чаянов отмечал: «Повторяя этапы развития промышленного капитализма, сельское хозяйство, выходя из форм полунатурального бытия, попадает под власть торгового капитализма, который подчас в форме весьма крупных торговых предприятий вовлекает в сферу своего влияния массы распыленных крестьянских хозяйств и, овладев связями этих мелких товаропроизводителей с рынком, хозяйственно подчиняет их своему влиянию и, развивая систему кабального кредита, превращает организацию сельскохо- зяйственного производства чуть ли не в особый вид раздаточной конторы, построенной на «системе выжимания пота»» [2].

В новейшей истории наблюдается приблизительно такая же картина. Сельскохозяйственные товаропроизводители зачастую предпочитают сбывать продукцию «с поля». Несмотря на то, что права собственности оказались тем или иным образом реализованы, либо через имущественные паи и земельные доли при приватизации колхозов и совхозов, либо через прямую покупку земли и средств производства на свободном рынке, проблема монополизма и высоких транзакционных издержек не позволили сформировать самоорганизующуюся инфраструктуру рынка, в которой сельхозтоваропроизводители могли бы свободно и прибыльно сбывать свою продукцию, а покупатели получать высококачественные продукты питания. Почему так происходит? Сельхозтоваропроизводители и потребители их продуктов находятся на довольно больших расстояниях друг от друга, а также во времени, сырье и полуфабрикаты проходят несколько операций производственного процесса до получения готового продукта. Инфраструктура рынка изменилась существенно, добавились новые участники воспроизводственного процесса, но одна проблема осталась в прежнем состоянии - уровень трансакционных издержек для сельскохозяйственного товаропроизводителя остался довольно высоким, что не позволяет им играть роль активного участника продовольственного рынка. Высокий уровень транзакционных издержек объясняется двумя причинами: географической и временной разобщенностью производителя и потребителя, что приводит к транспортным издержкам, а также к издержкам хранения, но при этом, играют роль затраты на организацию каналов сбыта - оптовую торговлю и розничный бизнес. Кроме того, важное значение имеет переработка сельскохозяйственного сырья и упаковка продукта. В сумме эти затраты оказываются неподъемными для сельскохозяйственного товаропроизводителя, что заставляет его принимать пассивное участие в воспроизводственном процессе и сбывать продукцию «с поля» по довольно низкой цене. Правильно отмечает исследователь Э.В.Эрдниева: «У сельскохозяйственного товаропроизводителя есть выбор путей реализации своих товаров. Если он продает продукты прямо потребителю, он может получить хорошую цену, но должен 
тратить время и прикладывать усилия (вложить труд) для их сбыта, одновременно осуществлять производство на предприятии. Другой путь продукта - «от ворот фермы»: его покупают посредники, которые выполняют функции хранения, транспортировки, подработки и переработки, упаковки в нужное время и в нужном потребителю месте» [3].

Эффективность сбыта сельскохозяйственного сырья и продуктов, таким образом, определяет, насколько сельское хозяйство интегрировано в воспроизводственный процесс. Если сбыт получает большую долю прибыли от продажи готовых продуктов, значит роль сельскохозяйственного производства как актора воспроизводственного процесса крайне слаба. В этой ситуации рыночная власть в большей степени оказывается в руках сбытового сектора, он и диктует условия функционирования рынков для всех остальных участников - как производителей сельскохозяйственного сырья и продуктов, так и конечных потребителей продуктов $[1,4]$.

В этих условиях от сбытовых фирм также зависит, какие цены формируются для производителя сырья и для потребителя конечного продукта при данном предложении и данном спросе на аграрные товары. В развитых странах сфера сбыта продовольствия довольно сильно развита и регулируется не только законами рынка, но и нормативными установлениями. Совершенно неверно предполагать, что законом можно установить цены на продукты, но можно сформировать для всех участников воспроизводственного процесса такие институциональные условия, что производство целесообразно во всех операциях воспроизводственного процесса. В настоящее время следует констатировать дисбаланс нормы прибыли в разных операциях воспроизводственного процесса, когда одни участники имеют очень высокий уровень, а другие - балансируют на грани рентабельности. Важно отметить, что такая ситуация не только ненормальна с точки зрения рыночных отношений, но и с позиций продовольственной безопасности, так как дисбаланс делает производство продуктов отечественного происхождения сложным и, как было еще совсем недавно, приводит к засилью импорта, так как сбытовые фирмы заинтересованы в гарантированных и крупных поставках, чего слаборазвитое сельское хозяйство предоставить не может.

Чаянов А.В. так описал сбытовой процесс сельскохозяйственных продуктов:

«В ходе изучения строения торгового аппарата для рынков сбыта различных сельскохозяйственных продуктов, мы можем отметить пять основных ступеней товарного пути сельскохозяйственных продуктов:

I. Распыленный по отдельным производителям товар собирается рядом скупщиков и прасолов и концентрируется в их руках.

II. Собранный скупщиками товар подвергается грубой сортировке и перевозится из мест сборки в местные центры оптовой торговли.

III. В оптовых центрах товар подвергается сортировке и распределению по направлениям дальнейшего движения.

IV. Собранный в центре и рассортированный товар перевозится в местные потребительские оптовые центры.

V. Из местных оптовых центров товар с помощью торгового распределительного аппарата (местных лавочников и других торговцев) поступает к распределителю».

За исключением некоторых особенностей и современных технологий, архитектура аграрного рынка слабо изменилась за почти вековую историю.

Это свидетельство укорененности такого института сбыта для аграрного рынка. Значит, существуют силы, которые поддерживают такую структуру рынка и уровень рыночной власти участников воспроизводственного процесса. Нельзя такую структуру признать эффективной из-за дисбаланса интересов и нормы прибыли среди участников воспроизводственного процесса. Хотя дисбаланс нормы прибыли в операциях внутри цепочки ценности характерен для любого производственного процесса [9], тем не менее, именно в аграрной сфере и продовольственном обеспечении он наиболее чувствителен для потребителей и производителей сельскохозяйственного сырья.

Как мы отмечали ранее, нормативное установление процесса ценообразования взамен рыночного недопустимо, так как подорвет эффективность всего воспроизводственного процесса, снизит налогооблагаемую базу, поэтому следует направить усилия к поиску институтов, способных опосредованно оказать влияние на процесс распределения прибыли внутри цепочки ценности от получения сырья до доведения готового продукта до конечного потребителя.

Опосредованное влияние может быть оказа- 
но путем усиления рыночной власти наиболее слабого участника воспроизводственного процесса - производителей сельскохозяйственного сырья и первичных продуктов [10,13].

Следует отметить, что в целях повышения эффективности колхозов, их подвергли реструктуризации и деколлективизации, в результате чего, по замыслу реформаторов, должен был образоваться слой эффективных фермеров - производителей сельскохозяйственных продуктов [12]. Авторы при этом делают важную оговорку: «Осуществление приватизационных программ необязательно способствует повышению эффективности хозяйствования». Главное заблуждение кроется в убеждении, что экономика капиталистического рынка возникнет спонтанно, как только утвердится частная собственность, введены свободные цены, осуществлена стабилизация денежной системы, созданы нерегулируемые, основанные на конкуренции рынки [7].

Германский опыт показывает вариант решения проблемы, когда сельхозтоваропроизводители - фермеры, как наиболее слабые участники воспроизводственного процесса, смогли усилить свою роль путем формирования кооперативов. Операции воспроизводственного процесса, которые характеризуются объединением потоков материальных ресурсов, могут быть переданы на исполнение кооперативам, участие в которых сельскохозяйственных товаропроизводителей позволяет им получить большую рыночную власть за счет обеспечения больших объемов стандартизированной продукции в понятные и прогнозируемые сроки. Так, баварские фермеры получают от кооперативов семенной материал, удобрения, технику, молодняк для выращивания и т.д., осуществляют производственный процесс в строгом соответствии с технологией, контроль за исполнением которой осуществляют специалисты кооператива. В определенные сроки фермеры сдают продукцию кооперативу, который обеспечивает не только сбор, но и переработку сырья на собственных перерабатывающих заводах. Кооперативы позволяют фермерам усилить свою рыночную власть за счет участия в управлении соседними операциями производственного процесса. Некоторые кооперативы оказываются основными акционерами перерабатывающих предприятий и торговых сетей, что усиливает их рыночную власть еще более, а процесс распределения прибыли делает более справедливым и интересным для производителей сель- скохозяйственного сырья. Следует оговориться, что европейская аграрная политика базируется на дотациях к ценам производителя за выполнение доведенной производственной программы, однако, для нашего случая этим основанием можно пренебречь, так как нас интересует лишь институциональная структура, позволяющая достичь более сбалансированного распределения прибыли между участниками воспроизводственного процесса.

Такая модель взаимоотношений участников воспроизводственного процесса в аграрной сфере была бы вполне применимой и для рынков стран ШОС, если бы не одно ограничение - низкий уровень доверия акторов друг к другу. Может показаться, что это чисто российская проблема, однако, это не так. Британский историк Дж. Хоскинг отмечает: «Западный мир переживает кризис доверия» [6]. Он говорит об утрате доверия граждан к своим государствам. Объяснение этого явления выходит за рамки нашего исследования, поэтому мы не будем его касаться, но лишь примем как данность [5]. Таким образом, доверие оказывается краеугольным камнем для усиления роли слабых участников аграрного рынка для выравнивания и более справедливого баланса прибыли и обеспечения продовольственной безопасности. Профессор Р. Локке утверждает: «Доверие можно создать! [8]». Формирование доверия в аграрной сфере вполне возможно, хотя на первый взгляд, и не совсем ясен путь достижения. Мы постараемся сформировать направление повышения доверия для аграрного рынка.

Базовой ступенью механизма повышения доверия в аграрном рынке выступает заинтересованность акторов. Без заинтересованности акторов в повышении доверия невозможно двигаться дальше. Доверие может стать интересным в том случае, если институциональные основания в аграрном рынке окажутся стабильными, в чем должно проявить свою заинтересованность государство и его органы, отвечающие за реализацию аграрной политики, а в более широком плане - органы, отвечающие за экономическую политику. Акторы довольно быстро откликнутся на стабилизацию институциональных условий расширением деловой активности, инвестиций и капитальных вложений. Вторая ступень механизма оказывается реализованной посредством активной роли политики государства в реализации институциональных реформ. Здесь 
наиболее востребованными окажутся проекты государственно-частного партнерства, доказавшие свою эффективность в инфраструктурных проектах. Поощрение кооперации и самоуправления (хотя бы на примере немецких союзов производителей различных видов сельскохозяйственных продуктов), а также выдвижение их инициатив на первый план в процессе выработки институциональных условий аграрного рынка, по сути, будет способствовать выравниванию правил поведения на рынке и самоконтроля.
Высшей точкой механизма повышения доверия для аграрного рынка выступает инфраструктура. Мы имеем в виду инфраструктуру рынка аграрных продуктов, которая формируется при условии доверия акторов по отношению друг к другу. Подрыв доверия должен наказываться исключением сельскохозяйственного товаропроизводителя из союза, широким распространением информации о недобросовестном его поведении на рынке и рисках взаимодействия с таким актором.

\section{Библиографический список}

1. BogovizA.V., Bugai Y.A., Osipov V.S. Import substitution in the agro-industrial complex in the interests of provision of food security: Option or necessity?// Advances in Intelligent Systems and Computing. 2018. 622. Pp. 37-43.

2. Chayanov A. The Theory of Peasant Economy. // The American Economic Association. 1966.

3. Эрдниева Э.В. Некоторые проблемы сбыта сельскохозяйственной продукции // Экономика и предпринимательство. 2014. № 11-3 (52-3). С. 407-409.

4. Gulyayeva T.I., Kuznetsova T.M., Gnezdova J.V., Veselovsky M.Y., Avarskii N.D. Investing in innovation projects in Russia’s agrifood complex // Journal of Internet Banking and Commerce. 2016. \#21 (Special Issue \#6).

5. Hosking G. Trust: Money, Markets and Society. 2010. Seagull Books.

6. Hosking G. Trust: a History. Oxford. 2014. Oxford University Press.

7. Kregel J., Matzner E., Graber G. Market shock. International Institute of the World. 1992. P.126.

8. Locke R. Building Trust //Paper presented at the Annual Meetings of the American Political Science Association. San Francisco. 2001.

9. Осипов В.С. Направления аграрной и промышленной политик России: от санкций к конкурентоспособному импортозамещению // Никоновские чтения. 2016. № 21. С. 113-115.

10. Евсеев В.О., Скрыль Т.В., Шавина Е.В., Осипов В.С., Невская Н.А. Промышленная политика России: политэкономические и региональные аспекты. Москва, Сер. Научная книга. 2016.

11. Silvestrov S.N., Zeldner A. G., Osipov V.S. Introduction to the Theory of Economic Dysfunction // Mediterranean Journal of Social Sciences. 2015. Vol. 6. \#3. Pp. 394-399.

12. Tillack P., Schultze E. Institutional problems of agricultural production. Agrifood complex of Russia on the market way // Analytical center of agrifood economics, Institute of transition economics. (2001).

13. Зельднер А.Г. Инвестиции как условие экономического роста АПК // Международный сельскохозяйственный журнал. 2005. № 5. С. 19-20. 


\title{
КРАУДИНВЕСТИНГ КАК НОВЫЙ СПОСОБ ФИНАНСИРОВАНИЯ ИННОВАЦИОННЫХ ПРОЕКТОВ
}

\author{
(c) 2018 Перепёлкин Вячеслав Александрович \\ доктор экономических наук, профессор кафедры мировой экономики \\ Самарский государственный экономический университет \\ 443090, г. Самара, ул. Советской армии, 141 \\ E-mail: slavaap@rambler.ru \\ () 2018 Фролова Кристина Алексеевна \\ Самарский государственный экономический университет \\ 443090, г. Самара, ул. Советской армии, 141 \\ E-mail: kitty-kriska@mail.ru \\ (c) 2018 Мухамадиева Лилия Наильевна \\ Самарский государственный экономический университет \\ 443090, г. Самара, ул. Советской армии, 141 \\ E-mail: muhamadievalilli@mail.ru
}

В статье подвергнут изучению краудинвестинг в качестве перспективного способа осуществления финансирования инновационных проектов. Проанализированы особенности краудинвестинга, его виды, потенциал применения в современных российских экономических условиях.

Ключевые слова: краудинвестинг, краудлендинг, стартап, инвесторы, краудинвестинговая площадка, микрофинансирование.

Развитие цифровых технологий и созданных на их основе средств коммуникации расширили спектр применяемых инструментов финансирования экономической деятельности, одним из новейших среди которых выступает краудинвестинг. Последний особенно актуален для малого инновационного бизнеса, лишенного доступа к финансированию с фондового рынка и ограниченного в получении средств от банков, хотя бы в в силу отсутствия кредитной истории [6].

Представляя собой нацеленный на финансовое участие в предпринимательских проектах, вид краудфандинга предполагает уже не безвозмездную помощь, а возврат предоставленных средств с дополнительной платой за их использование. Инвесторы получают долю в компании, рассчитывая на будущие прибыли или на заранее оговоренную величину дохода. Термины краудфандинг и краудинвестинг начинаются со слова «крауд», означающего «толпа, коллектив». В первом случае «толпа» лишь предоставляет для реализации проекта денежные средства, во втором - она инвестирует в проект. Разница состоит в том, что как своеобразное народное финансирование краудфандинг не предполагает прямого участия в развитии стартапа вкладчиков, всего лишь стремящихся поддержать на- чинающего предпринимателя с его интересной идеей [8]. Все, на что могут рассчитывать финансовые доноры проекта - это первыми приобрести созданный продукт по сниженной цене или получить подарки, привилегии.

В научной литературе краудинвестинг часто именуют акционерным краудфандингом, позволяющим на этапе становления стартапа привлечь внешнее финансирование для его реализации со стороны большого количества так называемых микроинвесторов, по отдельности обладающими небольшими суммами денег для вложений [2]. Субъектами процесса краудинвестинга здесь выступают: во-первых, создатели стартапа, нуждающиеся в деньгах на развитие и продвижение предпринимательского проекта инновационного содержания; во-вторых, верящие в хорошую перспективу стартапа микроинвесторы, готовые вкладывать в него пусть и небольшие, но реальные деньги; в-третьих, специализированные площадки - выступающие в роли посредников, благодаря которым находят друг друга организаторы проектов и инвесторы.

Краудинвестинговые площадки прежде всего дают оценку ищущим финансирования инновационным компаниям, выявляя и отсеи- 
вая мошеннические проекты. Важной задачей этих платформ также является контроль выплат прибылей вкладчикам и, в случае прекращения стартапом выплат, оказание помощи инвесторам в возврате вложенных средств. Источником дохода краудинвестинговых площадок выступает комиссионное вознаграждение от инвестируемой компания, в зависимости от площадки и конкретной сделки варьирующееся в пределах от 1 до 6,7\% от общей суммы инвестиций. Первой в мире краудинвестинговой площадкой в 2005 г. стала британская Zора. Год спустя в США появилась аналогичного назначения платформа под названием Prosper. Возникшая вскоре платформа Lending Club в 2014 г. провела IPO, принесшее ей около 5,4 млрд. долл. США.

В настоящее время наиболее популярными краудинвестинговыми площадками являются британские CrowdCube и Seedrs, американские Rabble и AngelList, германская Smava, израильская OurCrowd. В целом в США сегодня насчитывается более 340 площадок коллективного инвестирования, в Великобритании их больше 80, во Франции около полусотни. $\mathrm{B}$ России первой краудинвестинговой платформой стал появившийся осенью 2012 г. SmartMarket, менее чем через год прекративший свое существование. Позже ее судьбу повторили платформы VCStart, WeShare, закрывшиеся в 2015 г.. Пожалуй, самой известной из функционирующих ныне в данном бизнесе российских площадок является, начавшая работать в 2013 г. StartTrack. Как и любой инновационный бизнес, посредничество в процессе краудинвестинга представляет собой высокорискованную деятельность, успех в которой зависит не только от квалификации ее организаторов, но и от существования в достаточной степени благоприятной экономической и институциональной сред для ее ведения. В этом отношении Россия располагает большим потенциалом роста объемов рассматриваемой формы инвестирования, реализация которого будет происходить вместе с накоплением человеческого капитала и последующим усилением инновационной активности в экономике. В качестве примера можно привести экономику США, где активно развивающая технологические новшества Калифорния предложила рынку столько проектов, сколько НьюЙорк, Флорида, Техас и Иллинойс вместе взятые.

$\mathrm{K}$ настоящему времени в краудинвестинге широкое применение получило народное кредитование или краудлендинг, когда помимо возвращения вложенной суммы начисляется фиксированный процент прибыли [4]. Здесь четко оговаривается, когда и на каких условиях будут возвращены средства. Реже применяются роялти, позволяющие инвесторам рассчитывать на часть прибыли в случае успешности проекта, а размер вознаграждения ставится в зависимость от величины инвестиций. Такой вариант краудинвестинга популярен в мире искусства и развлечений, а именно, при съемках фильмов, записях музыкальных произведений, разработке компьютерных игр.

Стартовавший в 2012 г. в США подъем краудинвестинговой деятельности связывают со вступлением в силу закона о финансировании стартапов (Jumpstart Our Business Startups Act), регулярно вносимые поправки в который (подобные принятию третьей статьи, разрешающей мелким инвесторам данным способом инвестировать компании) обеспечивают либерализизацию условий осуществления рассматриваемой деятельности. Развернули сотрудничество с краудинвестинговыми площадками институциональные инвесторы, вкладывающие в проекты крупные суммы [7]. В 2015-2018 гг. число краудинвестинговых сделок стало меньше, но зато увеличился их средняя стоимость и совокупный объем вложений инвесторов. Так, в первый год после JOBS act с предложениями на краудфандинговые платформы вышло более 4700 компаний, а за последний год - только 550. Зато за первый год компаниями было привлечено 385 млн. долл., а за третий -603 млн. долл. Соответственно, вырос средний размер успешного размещения - с 405000 до 731000 долл., при этом “средний чек” от одного инвестора составлял от \$10000 до \$100000 долл. В результате, если в первый год после принятия в США JOBS act запланированную сумму получали 20,2\% компаний, то по итогам последних 12 месяцев этот показатель вырос до 30, 5\%. То есть вначале необходимые средства от инвесторов собирал каждый пятый проект, теперь - каждый третий. Пока подобных нормативных актов в России нет, хотя есть надежда на принятие внесенного весной 2018 г. законопроекта «Об альтернативных способах привлечения инвестиций». Пока же по сравнению с западным, российский краудинвестинг развит существенно слабее: за два последних года 28 российских стартапов привлекли через платформу StartTrack 507 млн. рублей 
или меньше 8 млн. долл. США. На платформе зарегистрирован 1261 инвестор, тогда как почти каждая из 16 американских платформ имеет десятки тысяч зарегистрированных инвесторов.

Впрочем, в последние годы объемы рынка краудинвестинга в нашей стране растут рекордными темпами: согласно оценке Банка России, объем вложений здесь за период 2015-2017 гг. увеличился в 7,9 раза - до 1,8 млрд. рублей [3]. Объективных причин такого рывка две: во-первых, банки пятый год подряд не наращивают и без того скромный портфель кредитования малого и среднего бизнеса, к тому же в до 80\% случаев отказывая соответствующим потенциальным заемщикам; во-вторых, инвесторам всё сложнее получить приемлемую доходность в классических инструментах, в частности, в депозитах в долларах США или в рублях. Поэтому все больше компаний и индивидуальных инвесторов ищут и находят альтернативу банкам в краудинвестинге (табл. 1). Условиями получения денег от инвесторов площадки выступают наличие положительных результатов деятельности компании на рынке и подтвержденный прогнозный спрос на ее товары.

Однако выбор вариантов при осуществлении краудинвестинга в российской экономике пока невелик [1], прежде всего из-за немногочисленности отечественных краудинвестинговых платформ. Среди них наибольшей популярностью пользуются следующие [5]:

1. StartTrack, работающая с 2013 г. как аналог британской Angellist. Минимальная сумма инвестиций составляет 100000 руб., а доходность - до 25\%. Предпочитает работать с фир- мами, ежемесячная выручка которых стартует от 10 млн. руб. и позволяет как приобретать доли в проектах, так и давать деньги предпринимателям в долг.

2. «Город денег» также работает с займами, но ограничивает только минимальный размер финансирования суммой в 50 тыс. руб. 79\% компаний, получивших финансирование через эту площадку, работают в сфере торговли или иных услуг.

3. «Поток», являющийся проектом Альфа-Банка, установил минимальную сумму, которую необходимо продержать хотя бы в течение полугода, на уровне в 10000 руб. Банк обещает доходность равную 30\% годовых;

4. Venture Club. Более $94 \%$ совокупного оборота данной площадки приходится на инвестиции в капитал, но площадка также предлагает клиентам частное финансирование по прямому договору займа. При этом все клиенты Venture Club являются информационно-коммуникационными компаниями, работающими в сферах Consumer Internet, SAS, В2B SAS и Hardware.

Сегодня представляются реальными три направления развития российского краудинвестинга:

1. Кооперация с банками. Краудинвестинговые площадки предлагают банкам привлекать частное финансирование для юридических лиц, которым отказали в банковском кредите или выдали кредит в недостаточном объеме. Например, «Уралсиб» предлагает клиентам воспользоваться услугами площадки StartTrack. Банкам выгодно предлагать клиентам частное финансирование, чтобы повысить лояльность заемщи-

Таблица 1. Динамика показателей краудинвестирования в России

\begin{tabular}{|l|c|c|c|}
\hline \multicolumn{1}{|c|}{ Показатели } & 2015 г. & 2016 г. & 2017 г. \\
\hline Инвестиции в капитал (млн.руб.) & 232 & 1505,5 & 1837,7 \\
\hline Профинансировано компаний & 81 & 277 & 871 \\
\hline Количество инвесторов & 105 & 1313 & 14466 \\
\hline
\end{tabular}

Источник. Ресурс: https://incrussia.ru/understand/infografika-kak-ustroen-rynok-kraudinvestinga-v-rossii.

Таблица 2. Объем привлеченных инвестиций на некоторых российских краудинвестинговых площадках

\begin{tabular}{|l|c|c|c|}
\hline \multicolumn{1}{|c|}{ Название компании } & $\begin{array}{c}\text { Объем инвестиций, } \\
\text { млн. руб. }\end{array}$ & Площадка & Сфера деятельности \\
\hline Футибол & 352,4 & StartTrack & Спорт \\
\hline Интернет-магазин детских товаров & 3,1 & Город Денег & E-commerce \\
\hline GetShop TV & 45 & Venture Club & Реклама \\
\hline
\end{tabular}

Источник. Ресурс: https://incrussia.ru/understand/infografika-kak-ustroen-rynok-kraudinvestinga-v-rossii/ 
ков и минимизировать кредитные риски.

2. Увеличение числа инвесторов. Количество людей, которые совершили не менее одной сделки через краудинвестинговые площадки, за 2017 г. выросло более чем в 11 раз - до 14 тыс. человек. Вместе с тем, краудинвестинговым инструментам присуща низкая ликвидность, поскольку инвестору можно выйти из проекта не в любой момент. Для не умеющих планировать людей это является существенным ограничением.

3. Повышение уровня насыщения рынка и специализация. Работая по одной модели, российские компании стараются создать уникальный продукт и делают акцент на различных объемах финансирования и различных типах корпоративных клиентов. Специализация, низ- кое насыщение рынка и отсутствие специального регулирования позволяют краудинвестинговым площадкам избегать прямой конкуренции и даже сотрудничать (например, рекомендуя инвесторам либо реципиентам, не подошедшим по критериям, другие площадки).

Таким образом, выбор при краудинвестинге в современной России весть между соответствующими западными платформами и немногочисленными отечественными сервисами. При этом одни эксперты утверждают, что начинающему бизнесу бессмысленно выходить на западные краудинвестинговые площадки без проверки своей эффективности на Родине. Другие, наоборот, предрекают скорый бум краудинвестинга и предлагают юридически легальные варианты обхода законодательных барьеров.

\section{Библиографический список}

1. Зейналов А.А. Практика применения краудтехнологий в Российской Федерации / А.А. Зейналов, Ю.М. Грузина, Д.А. Ильенков // Современная наука. Серия Экономика и право. 2016. № 11. С.41-45

2. Нешитой А.С. Финансы и кредит: Учебник / А.С. Нешитой. 6-е изд., перераб. и доп. Москва. 2011. 576 с.

3. Богомолова А. Инфографика: как устроен рынок краудинвестинга в России. 2017. Режим доступа: https:// incrussia.ru/understand/infografika-kak-ustroen-rynok-kraudinvestinga-v-rossii/, свободный.

4. Евдокимов С.С., Кобышев М.С. Современные модели финансирования стартапов // Финансы и кредит. 2017. Режим доступа: https://cyberleninka.ru/article/n/sovremennye-modeli-finansirovaniya-startapov, свободный.

5. Соколов И.Н., Солохин А.А., Фияксель Э.А. Сравнительный анализ российских краудинвестинговых платформ // Инновации. 2017. Режим доступа: https://cyberleninka.ru/article/n/sravnitelnyy-analiz-rossiyskihkraudinvestingovyh-platform, свободный.

6. Фияксель Э.А., Солохин А.А., Соколов И.Н. Краудинвестинг. Обзор исследований и промежуточные результаты развития // Инновации. 2017. Режим доступа: https://cyberleninka.ru/article/n/kraudinvesting-obzorissledovaniy-i-promezhutochnye-rezultaty-razvitiya, свободный.

7. Hornuf L., Schwienbacher A. Funding dynamics in crowdinvesting // Research Papers in Economics. № 9(15). 2015. Режим доступа: https://www.econstor.eu/handle/10419/121440, свободный.

8. Schondorfer S., Ebert T. The crowdinvestor - What drives investors' decision-making to participate in crowdinvesting? // COPENHAGEN BUSINESS SCHOOL. 2014. Режим доступа: http://studenttheses.cbs.dk/ bitstream/handle/10417/5083/tim_ebert_og_simone_schöndorfer.pdf?sequence=1, свободный. 

ЭКОНОМИКА. ЭКОНОМИЧЕСКИЕ НАУКИ

\section{ЭКОНОМИКА И УПРАВЛЕНИЕ НАРОДНЫМ ХОЗЯЙСТВОМ}





\section{ФОРМИРОВАНИЕ ОРГАНИЗАЦИОННОЙ КУЛЬТУРЫ КОРПОРАЦИЙ ОБОРОННЫХ ОТРАСЛЕЙ}

\section{(c) 2018 Базадзе Наталья Григорьевна}

доктор экономических наук, профессор

профессор кафедры «Менеджмент и маркетинг высокотехнологичных отраслей промышленности» Московский авиационный институт (Национальный исследовательский университет)

125993, г. Москва, Волоколамское шоссе, 4

E-mail: n-bazadze@yandex.ru

Корпоративная культура в оборонных отраслях следует формировать и развивать, в первую очередь, в части культуры организации труда, организации производства и управления на более ранних этапах жизненного цикла человеческих ресурсов - этапах подготовки потенциального персонала.

Ключевые слова: корпоративные структуры, специфика оборонных отраслей, корпоративная культура, организационная культура, уровни проявления корпоративной культуры, формирование организационно-управленческих компетенций.

\section{1. Роль корпоративной культуры}

Корпоративные структуры современного оборонного комплекса России сформировались в результате реорганизации системы управления промышленностью и структуры управления тех производственных и научно-производственных объединений, которые создавались, в основном в 60-е годы прошлого столетия. Дальнейшее организационное преобразование шло за счет интегрирования и акционирования, создания корпоративных структур холдингового типа. Управление такими крупными структурами, которые в значительной своей части являются лидерами глобального рынка вооружений, перестраивалось с учетом мировых достижений менеджмента, к которым причисляют общую корпоративную культуру.

Формированию и развитию корпоративной культуры уделяют большое внимание именно в крупных структурах, как в России, так и за рубежом, как инструменту, позволяющему сохранить целостность корпоративного образования и узнаваемость бренда. Развитую корпоративную культуру как совокупность основополагающих ценностей, убеждений, социальных норм и уступок, разделяемых всеми членами социумной группы, принято относить к ключевым факторам успеха, поскольку она обеспечивает интеграцию и взаимодействие всех категорий персонала внутри корпорации. Эта совокупность основных ценностей и поведенческих норм, передаются всем поступившим на работу сотрудникам как правильные для данной структуры, как только начинающим свою производствен- ную карьеру выпускникам учебных заведений, так и специалистам и руководителям с наличием стажа работы.

\section{2. Процессы формирования корпора-} тивной культуры

Формирование ценностей и поведенческих норм, значимых для эффективной работы на оборонных предприятиях, весьма длительный процесс. Начальной точкой этого процесса являются жизненные ценности, формирующиеся у работников, как носителей корпоративной культуры, в подростковом возрасте, по утверждению социологов до 12 лет и культурные нормы, распространенные в регионе проживания. Далее они развиваются, трансформируются при все более разнообразной и масштабной социализации личности, встречая на своем жизненном пути все большее количество сообществ, оказывающих влияние на пересмотр отношения к себе и к системе взаимоотношений с другими. Во втором случае для трудоспособного населения значимы и, соответственно, могут различаться - системы взаимоотношений в рабочей (производственной) среде и системы взаимоотношений с близкими (большое число контактов) и малознакомыми (малое число контактов) людьми.

Сейчас на отечественных предприятиях оборонных отраслей работает значительная численность персонала, чьи жизненные ценности формировались в эпоху социализма. Молодые специалисты и рабочие, начинающие свою производственную карьеру родились в эпоху «дико- 
го рынка», что неизбежно оказало влияние на их ценностные установки.

Под влиянием почти трех десятилетий эпохи трансформации отечественной экономики, личные жизненные ценности работников старших возрастных категорий изменились в большей или меньшей степени, как по разным регионам, так и по разным профессиональным группам. Так, в отраслях реального сектора экономики, в частности в оборонных отраслях, сохранились ценностная ориентация на коллективизм. В отраслях финансового, торгово-посреднического секторов, сектора услуг - преобладает ориентация на индивидуальный профессиональный рост и вознаграждение. Весьма заметны эти различия для Москвы - сосредоточия финансовых потоков и регионов - производителей высокотехнологичной продукции.

Таким образом, в числе значимых факторов для формирования адекватной требованиям времени корпоративной культуры, следует выделить:

- соотношение различных возрастных групп среди персонала, жизненные ценности и поведенческие нормы которых формировались в разных экономических системах;

- различия и сходства национально-этнических норм и кодексов поведения у разных работников и на разных стадиях жизненного цикла у одного работника, например, на стадии подготовки и на стадии работы в регионах обучения и регионах трудоустройства.

\section{3. Специфика корпоративной культуры} отечественных оборонных отраслей

Среди специфических особенностей корпораций оборонных отраслей, отражающихся в корпоративной культуре:

1) большое разнообразие профессиональных категорий персонала, как следствие много передельного производства, подготовка которых ведется в разных регионах страны в различных учебных заведениях;

2) рост скорости обновления технической и инструментальной базы производства и управления с большим количеством используемых новых информационных технологий, быстрее осваиваемых молодым поколением;

3) наличие персонала разных возрастных категорий как следствие длинноциклового производства (длительного цикла изготовления продукции);
4) замкнутость контура управления, жесткие требования соблюдения дисциплины и режима;

5) широкий территориальный разброс структурных единиц в рамках федеральных границ и большое число кооперационных связей на территории страны и за рубежом.

Большая часть российских оборонных корпораций холдингового типа, где отдельные хозяйствующие субъекты или обособленные структурные подразделения (филиалы и представительства) территориально расположены в различных районах и регионах страны. Так, например холдинг «Вертолеты России» - один из лидеров глобального рынка вертолетостроения, включает в свой состав конструкторские бюро, производственные, авиаремонтные и сервисные компании, расположенными в разных Федеральных округах и краях страны. Головной офис и вертолетный завод имени Михаила Миля и находятся в Москве, другие - в Подмосковье, Татарстане, Бурятии, Башкортостане, Приморском крае, Пермском крае, Ростовской области Южного федерального округа. Создание единой корпоративной культуры таких структур - процесс длительный, должен начинаться в рамках подготовки потенциального персонала в профильных учебных дисциплинах при формировании не только профессиональных, но и личностно-деловых компетенций.

\section{4. Структура корпоративной культуры как объекта управления}

Проявления корпоративной культуры отмечаются на трех уровнях:

1. Внешний, как правило, визуальный - дизайн офисов, дресс-коды, сувенирная атрибутика, протоколы и церемонии. Эти признаки легко наблюдаемы.

2. Внутренний - поведенческий уровень. Здесь оцениваются поведенческие модели работников. Это более сложный объект для исследования, он может быть представлен двумя компонентами действиями работника и его реакцией.

Поведенческие модели - совокупность действий работника и его реакции на окружающую среду, условия процесса работы, поведения других людей внутри и вне его рабочей группы.

Для оценки поведенческих моделей и выделения базовых типов предлагается четырехоконная панель (рисунок Варианты поведенче- 
ских моделей в корпоративных структурах), где в качестве оценочных шкал выбираются эффективность действий работника в коллективном трудовом процессе, с минимальными суммарными затратами на производство продукции требуемого качества, и адекватность реакции работников, определяемую уровнем соответствия корпоративным нормам. Эффективные действия - действия, которые приводят к достижению поставленной работником (работнику) цели в заданные сроки с наименьшими затратами.

3. Глубинный - уровень убеждений - основополагающие ценности организации, которые разделяются всеми членами этого социума и повторяют базовые ценности основателей, владельцев или топ-менеджеров компании, формируется под влиянием национально-этнической культуры региона местонахождения компании и, как правило, религиозной культуры этого региона. Основу развития американской бизнес-культуры, которая является прототипом культуры взаимоотношений современной рыночной экономики, составляет протестантская этика. Российская федерация - многоконфессиональная страна, большая часть населения которой - православные христиане и мусульмане.

Внешний уровень - весьма актуален для коротких внешних контактов, весьма значим для репрезентативности корпорации высшим уровнем руководства. Поведенческий уровень весьма актуален для руководителей среднего и первичного звена, специалистов и рабочих для организации эффективной работы внутри контура управления предприятием, входящим в корпоративную структуру, и для корпорации в целом. Причем культура отдельной структурной единицы может представлять собой субкультуру, повторяющую нормы всей корпорации, но частично включающая и специфичные нормы, свойственные только этому предприятию, вследствие его роли в общей корпоративной структуре, его территориальному расположению и доминирующей национальной культуре, возрасту организации и преобладающей возрастной группе персонала. В данном контексте корпоративную культуру следует рассматривать как организационную культуру - культуру орга-

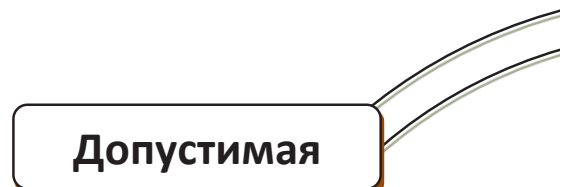
Оптимистичная
реакция, соответствующая
нормам компании при неоптимальных и нескоординированных действиях.

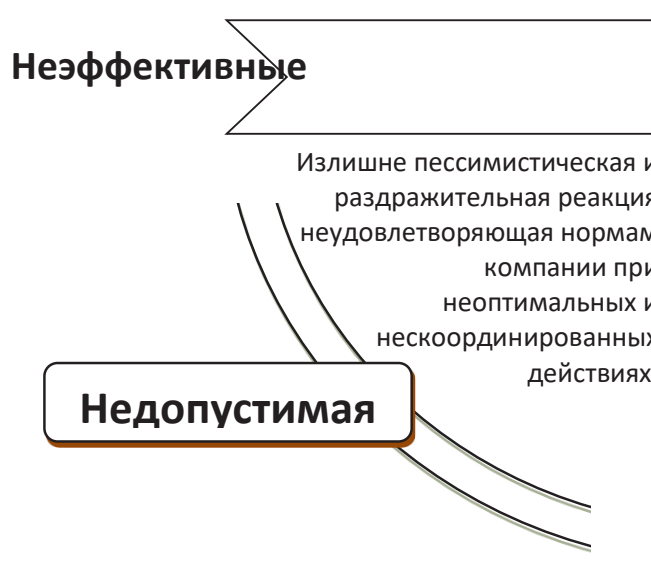

\section{Адекватная}

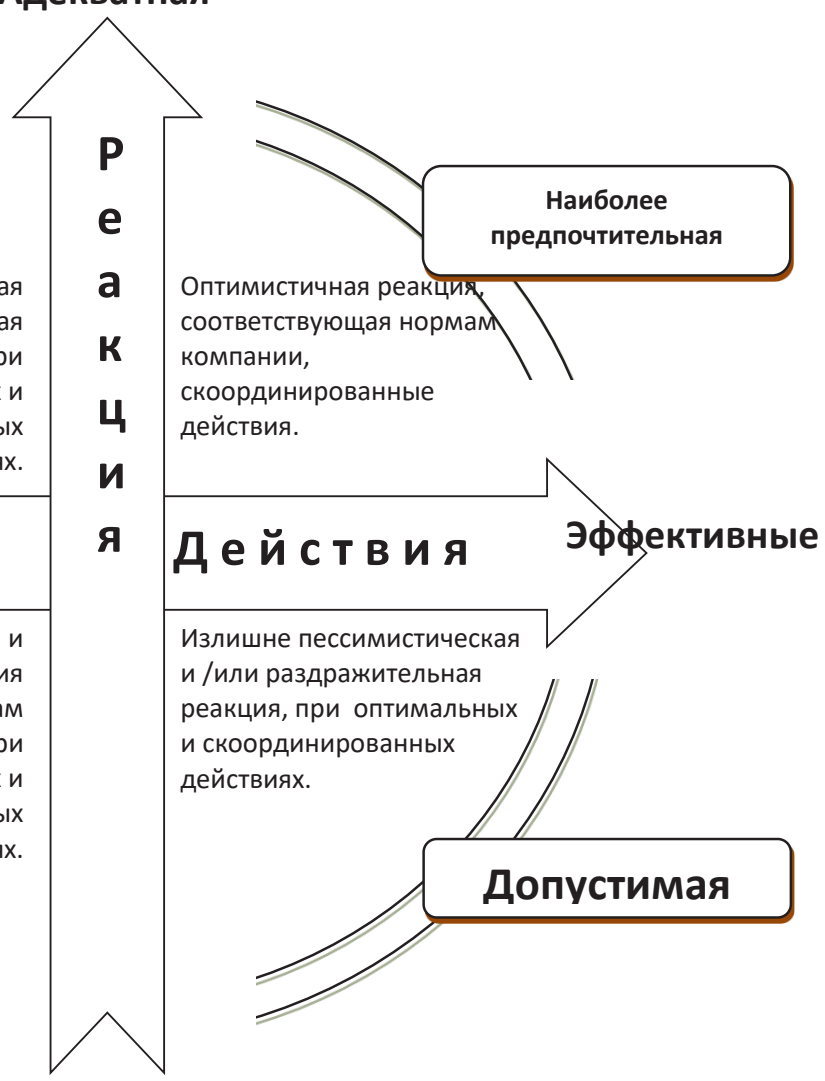

\section{Неадекватная}

Рис. Варианты поведенческих моделей в корпоративной культуре 
низации труда, организации производства, организации управления, включая и культуру организации рабочих мест.

Основание этой конструкции определяет надежность корпоративной культуры как инструмента управления. Поэтому перечень жизненных ценностей необходимо пополнять и пересматривать на этапе начала и прохождения трудового пути как начинающего работника (молодого рабочего и специалиста), так и на этапе действующего кадрового состава с высокой квалификацией.

На этом основании базируются такие востребованные в сегодняшней турбулентной экономике личностно-деловые компетенции как:

- физическая и психоэмоциональная работоспособность;

- эффективные межличностные коммуникации;

- работа в эффективной рабочей группе и команде;

- работа в мультизадачном режиме;

- скорость освоения нового, быстрая адаптация к изменениям.

\section{5. Заключение}

1. Корпоративная культура активно осваивается в оборонной отрасли на внешнем, представительском уровне. Пора осваивать более глубокие уровни - поведенческий и ценностный.

2. В корпоративную культуру следует вернуть организацию труда, производства и управлению, выстроенную на нормах работы с инновационными производственными и информационными технологиями.

3. Формирование и развитие личностно-деловых компетенций как процесс гораздо более продолжителен, чем процесс формирования отдельных профессиональных компетенций. Таким образом, действующие программы обучения необходимо дополнять новыми видами занятий междисциплинарного характера, предназначенных для выполнения рабочими группами разного уровня интегрирования трудового процесса - индивидуального, попарного, малой рабочей группой, большой рабочей группой в рамках одного и нескольких профилей (направлений подготовки).

\section{Библиографический список}

1. Адизес Ицхак. Размышления о менеджменте / Ицхак Адизес. Москва. 2011. 102 с.

2. Армстронг М. Практика управления человеческими ресурсами. 10-е издание. Пер. с англ/под ред. С.К. Мордовина. Санкт-Петербург. 2012. 848 с.

3. Базадзе Н.Г. Управление персоналомв сфере наукоемкого бизнеса. Учебное пособие. Москва. 2002. 248 с.

4. Базадзе Н.Г., Шеленкова Е.В. Проблемы развития компетенций по организационным коммуникациям для корпоративных структур авиастроительной отрасли // Электронный научный журнал «Труды МАИ». Выпуск № 59, 2012 г.

5. Гудкова, Т.В. Особенности корпоративной культуры российских компаний: моногр. Москва. 2016.168 с.

6. Гэлэгер Р. Душа организации. Как создать успешную корпоративную культуру. Москва. 2006. 352 с.

7. Лайкер Д. Корпоративная культура Тоуота. Уроки для других компаний. Москва. 2017. 385 с.

8. Емельянов, Ю.С. Человеческий капитал в модернизации России. Институциональный и корпоративный аспекты. Москва. 2014. 819 с. 
DOI: $10.14451 / 3.40 .41$

\section{АКТУАЛЬНЫЙ ПОДХОД К РАССМОТРЕНИЮ ИННОВАЦИЙ В ИНВЕСТИЦИОННО-СТРОИТЕЛЬНОМ КОМПЛЕКСЕ РОССИИ}

\section{(C) 2018 Беляева Елена Юрьевна}

аспирант кафедры экономики и управления предприятиями и производственными комплексами

Санкт-Петербургский государственный экономический университет

191023, г. Санкт-Петербург, ул. Садовая, д. 21

E-mail: lenaprokopenkova@mail.ru

В статье отражены последние тенденции в инновационно-экономическом поле строительной индустрии. В частности, актуализирована цель применения инноваций и предложены принципы для достижения поставленной цели применительно к инвестиционно-строительному комплексу с теоретической стороны вопроса. Также охарактеризована практическая сторона проблемы инноваций и предложены механизмы преодоления препятствий для инвестиционно-строительного комплекса. Рекомендовано комплексное применение видов инноваций.

Ключевые слова: инвестиционно-строительный комплекс, инновации, экономический эффект, циифровизация, социальные риски.

Различные вопросы, связанные с инновациями в строительстве, рассмотрены в работах российских учёных: Алексеева А.А. [1], Асаула А.Н. [2], Полякова Е.К. [3], Соколовой С.А. [4], Страховой А.С. [5] и др.; зарубежных исследователей: Bock T. [11], Czarnecki L. [12], Meng X. [13], Shibeika A. [14], Sinem Mollaoglu [15], и др.

Актуальность вопроса инноваций в инвестиционно-строительном комплексе (далее - ИСК) также подтверждается анализом научной литературы [10], проведенным автором по ключевым фразам «инновации в строительстве» и «строительные инновации»: в сумме было выявлено 1649 работ за период 2010-2017 гг. С уверенностью можно заявить, что интерес к теме инноваций в строительной отрасли с каждым годом

возрастает - это отражает линия тренда на рисунке 1.

Подходы к определению инноваций в ИСК изменялись наряду с общим определением. Действительно, подход выделения инноваций лишь как научно-технического прогресса устарел, и на сегодняшний день фокус исследователей направлен на изучение инноваций по видам, т.е. маркетингового, процессного, продуктового, организационного характера.

На современном этапе, безусловно, инновация направлена не только на научно-технический, но и на экономический, и социальный эффекты. Данный подход поддерживается и руководством Осло [16], однако автор считает необходимым дополнить применение инноваций

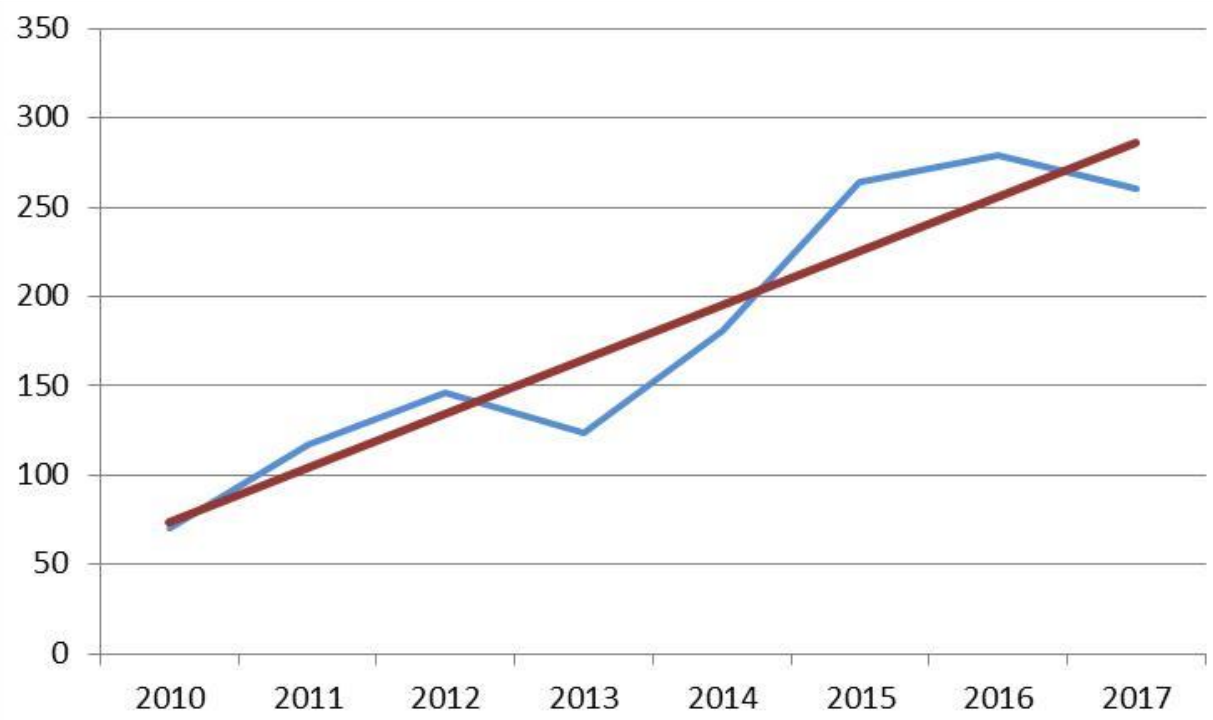

Puc. 1. График тенденции исследования инноваций в строительстве 
в направлении охраны окружающей среды, выделяя тем самым экологический эффект.

Основная цель инноваций заключается в получении полезного эффекта и устойчивого развития комплекса в целом. Данная цель может быть достигнута за счет соблюдения следующих принципов:

1. Принцип научно-технического прогресса, который заключается в традиционной инновации (улучшении и усовершенствовании продукта или технологии).

2. Принцип экономической эффективности (применяемые инновации должны быть экономически обоснованы и их использование должно приносить прибыль).

3. Принцип экологичности (является актуальным, поскольку согласно природоохранному законодательству необходимо соблюдать законодательно-правовые рамки в части нормирования выбросов загрязняющих веществ в воздушное пространство, в водные ресурсы, земельные ресурсы и недра).

4. Социальный принции (инновации в плане организации работы помогают создавать новые группы взаимодействия людей, что нацелено на более успешное внедрение инновации и развитие общества в целом).

Инновации в инвестиционно-строительном комплексе должны носить взаимодействующий характер, так как полезный эффект от их применения при этом будет повышаться. Определённо, при осуществлении лишь продуктовой инновации её эффективность без применения других видов инноваций (маркетинговой, процессной, организационной) не будет максимальна. Данный подход возникает из зарубежного опыта

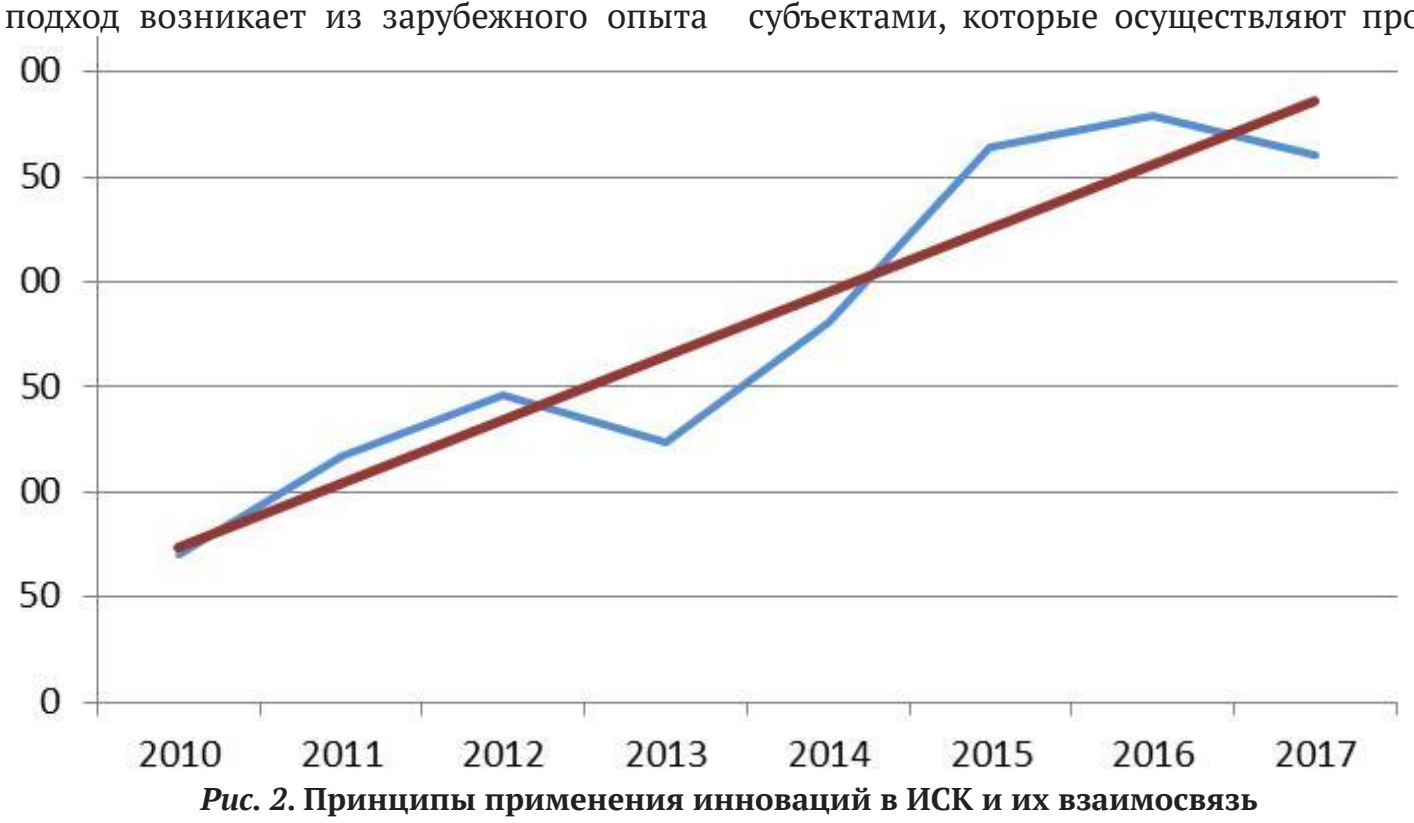

применения инноваций [16]. На рисунке 2 графически отражена взаимосвязь инноваций в ИСК и принципов их применения.

С практической стороны вопроса, проблема инноваций в инвестиционно-строительном комплексе России стоит особенно остро. Согласно указу Президента [8] необходимо не только увеличить темпы ввода жилых объектов в 1,76 раза (с 79,2 $\mathrm{m}^{2}$ [9] до $140 \mathrm{~m}^{2}$ ), но и создавать новое качество жилья. Данная задача может быть выполнена за счёт комплексного выполнения мер по внедрению инноваций. Существующие проблемы и разработанные автором предложения для достижения данной цели представлены в табл.

Все вышеперечисленные проблемы приводят к удлинению процесса создания или реконструкции строительного продукта (здания или сооружения) и увеличивают потери в виде транзакционных издержек.

K ключевым современным проблемам автор относит не завершенный этап цифровизации, медленное внедрение инноваций в повседневную практику, отсутствие активного интереса к моделям СІМ-моделирования. Цифровизацию на сегодняшний день необходимо рассматривать как механизм решения проблем взаимодействия поставщиков, застройщиков и потребителей - своевременное и прозрачное информационное поле позволит снизить негативные эффекты.

Существуют и другие барьеры, которые замедляют введение инноваций в ИСК. К ним автор относит социальные риски: несработанность коллектива, отсутствие взаимопонимания между субъектами, которые осуществляют проектную 
Таблица. Проблемы внедрения инноваций в ИСК и возможные пути решения

\begin{tabular}{|c|c|c|}
\hline Проблема и ее расшифровка & Предложения автора & Ответственные субъекты ИСК \\
\hline \multicolumn{3}{|c|}{ Продуктовые и процессные инновации } \\
\hline $\begin{array}{l}\text { Медленное внедрение инноваций } \\
\text { в повседневную практику: лишь } \\
\text { 8,8\% обследованных организаций } \\
\text { внедрили данный вид инноваций } \\
\text { [7] }\end{array}$ & $\begin{array}{l}\text { Увеличение затрат на инновации; } \\
\text { Создание отделов по разработке и } \\
\text { внедрению инноваций для ускоре- } \\
\text { ния адаптации технологии; } \\
\text { Адаптация зарубежного опыта; } \\
\text { Активное использование систем } \\
\text { «нового проектирования»: } \\
\text { ВІМ - информационное модели- } \\
\text { рование проекта (экономическая и } \\
\text { техническая составляющие); } \\
\text { СІМ - полное моделирование гра- } \\
\text { достроительной ситуации }\end{array}$ & $\begin{array}{l}\text { Решение проблемы лежит на стро- } \\
\text { ительной организации: } \\
\text { - Проектные бюро } \\
\text { - Подрядчики } \\
\text { - Застройщики } \\
\text { - Технические заказчики } \\
\text { - Поставщики }\end{array}$ \\
\hline $\begin{array}{l}\text { - полное отсутствие у 20,9\% [6] } \\
\text { населения России (пользователей } \\
\text { объектов недвижимости) возмож- } \\
\text { ностей использования технологии } \\
\text { Интернет }\end{array}$ & \multirow[t]{3}{*}{$\begin{array}{l}\text { Завершение первого этапа цифро- } \\
\text { визации для городов России; }\end{array}$} & \multirow[t]{3}{*}{$\begin{array}{l}\text { Решение данного вопроса на- } \\
\text { ходится в функционале испол- } \\
\text { нительной власти субъектов РФ } \\
\text { (департаментов и министерств) }\end{array}$} \\
\hline $\begin{array}{l}\text { - доступ к сервисам и услугам } \\
\text { (ЖКХ, сервис «Госуслуги» и др.) }\end{array}$ & & \\
\hline $\begin{array}{l}\text { - поиск актуальной информации } \\
\text { для приобретения качественного } \\
\text { жилья (реестр застройщиков) для } \\
\text { покупателей объектов недвижи- } \\
\text { мости }\end{array}$ & & \\
\hline $\begin{array}{l}\text { Низкий уровень производства } \\
\text { инновационных материалов }(5,3 \%) \\
\text { [9] }\end{array}$ & $\begin{array}{l}\text { Модернизация производств: } \\
\text { переход на выпуск новых матери- } \\
\text { алов (быстровозводимые блоки, } \\
\text { «умные» материалы: бетон, кир- } \\
\text { пич и др.) }\end{array}$ & Производители материалов \\
\hline \multicolumn{3}{|c|}{ Организационные инновации } \\
\hline $\begin{array}{l}\text { 2,8\% организаций используют ор- } \\
\text { ганизационные инновации [7] } \\
\text { Устаревшие формы и методы } \\
\text { управления проектом, несоответ- } \\
\text { ствующие современным реалиям, } \\
\text { приводят к удорожанию материа- } \\
\text { лов, работ и услуг, а также прино- } \\
\text { сят сверхнормативные временные } \\
\text { потери }\end{array}$ & $\begin{array}{l}\text { Повышение способности компа- } \\
\text { ний к заимствованию и адаптации } \\
\text { технологий; } \\
\text { Адаптация зарубежного опыта; }\end{array}$ & $\begin{array}{l}\text { Руководители организаций, заня- } \\
\text { тых в строительстве }\end{array}$ \\
\hline \multicolumn{3}{|c|}{ Маркетинговые инновации } \\
\hline $\begin{array}{l}\text { Являются инструментом продаж } \\
\text { и оказания услуг. Низкий уровень } \\
\text { развитости данного вида иннова- } \\
\text { ций (1,7\% компаний применяют } \\
\text { данные инновации [7]) приводит к } \\
\text { снижению интереса покупателей } \\
\text { объектов недвижимости }\end{array}$ & $\begin{array}{l}\text { Использование новых методов } \\
\text { продаж, способов сотрудничества } \\
\text { и рекламного продвижения }\end{array}$ & $\begin{array}{l}\text { Служба маркетинга строительных } \\
\text { организаций }\end{array}$ \\
\hline
\end{tabular}

работу. Также необходимо отметить и другие факторы, ограничивающие внедрение инноваций в ИСК: низкую потребность строительного рынка в инновациях, низкую рыночную конкуренцию между предприятиями, недостаток хороших идей, фокус строительных предприятий лишь на продуктовых инновациях (материалах для проведения строительно-монтажных работ), отсутствие стимулов для внедрения инноваций в строительную индустрию.

Дефицит инноваций и неверное их внедрение в строительной отрасли приводит к экономическим потерям на всех уровнях - отрасли, комплекса, отдельной фирмы. Таксономический расчёт потерь производится в каждом отдельном случае индивидуально и носит довольно трудоёмкий характер. 


\section{Библиографический список}

1. Алексеев А.А. Механизм технологических инноваций в строительстве // Экономические науки. 2015. № 10(131). С. 73-76.

2. Асаул А.Н. Инновации в инвестиционно-строительной сфере: учеб. пособие для академического бакалавриата / А.Н. Асаул, М.А. Асаул, Д.А. Заварин, Е.И. Рыбнов; под ред. А.Н. Асаула. Москва. 2017. 207 с.

3. Поляков Е.К. Обоснование внедрения единой системы диспетчеризации и регулировании инженерными сетями при управлении и эксплуатации зданий и сооружений /Е.К. Поляков, П.Г. Грабовый// Экономика и предпринимательство. 2018. № 1(90). С. 1085-1089.

4. Соколова С.А. Применение инновационного модульного строительства в пригородных зонах/ С.А. Соколова [и др.] // Экономика и предпринимательство. 2016. № 8 (73). С. 950-954.

5. Страхова А.С. Инновационные технологии в строительстве как ресурс экономического развития и фактор модернизации экономики строительства /А.С. Страхова, В.А. Унежева// Вестник Белгородского государственного технического университета им. В.Г. Шухова. 2016. № 6. С. 263-272.

6. Исследование НИУ «Высшая школа экономики» и «Яндекс. Такси»: «Цифровизация в малых и средних городах России», 2018. Презентация. URL: https://www.hse.ru/data/2018/06/06/1149766040/2018-06-GSU-HSE_ pres_v6.pdf (дата обращения: 19.10.2018) 


\title{
ФУНКЦИОНИРОВАНИЕ ЭТНОРЫНКОВ В ЭКОНОМИКЕ РЕГИОНОВ ЮГА РОССИИ
}

\author{
(c) 2018 Кетова Наталья Петровна \\ заслуженный деятель науки РФ \\ доктор экономических наук, профессор, зав. кафедрой «Маркетинг и коммуникации в бизнесе» \\ Южный федеральный университет \\ 344002, г. Ростов-на-Дону, ул. М. Горького, 88 \\ E-mail:kmik2012@mail.ru \\ (c) 2018 Овчинников Виктор Николаевич \\ Заслуженный деятель науки РФ, \\ доктор экономических наук, профессор \\ профессор-консультант кафедры управления развитием пространственно-экономических систем \\ Южный федеральный университет \\ 344002, г. Ростов-на-Дону, ул. М. Горького, 88 \\ E-mail: ovn@aaanet.ru
}

В статье представлены результаты разработки проблем: выявления функциональной роли этнических рынков в экономике регионов Юга России; идентификации их позиций и определения векторов ориентации на удовлетворение специфических видов спроса целевых аудиторий потребителей.

Ключевые слова: экономика региона, этнические рынки, целевые аудитории, этнические предпочтения покупателей, векторы ориентации, территориальное пространство.

Этнические рынки: специфика, условия формирования, субъектная определенность.

Этнорынки - достаточно сложный феномен, охватывающий совокупность экономических, демографических, расселенческих и межэтнических взаимоотношений, реализуемых в трансакциях. Функционирование таких рынков становятся одним из факторов развития социально-экономической среды в России и в других странах, но до сих пор остаётся мало изученным.

Локальный этнорынок (от англ. local market) - это рыночный сегмент национальной экономики, выделяемый по географическому, национально-этническому, товарному, функциональному и другим признакам [1]. Данный рынок предполагает концентрацию на одном или нескольких сегментах, отличающихся этноэкономической спецификой. Очевидно, что в этом смысле правомерно говорить лишь о рынках «B2C», т.е. рынках, на которых осуществляется купля-продажа товаров для конечного потребления товаров и услуг. Ибо на рынках «В2В», где осуществляется сбыт продукции производственно-технического назначения, предназначенной для производства других товаров и оказания услуг, предметы трансакций этноэкономической спецификой, практически, не обладают.

Под словом «локальный этнический рынок» предлагается понимать территориально ограниченную и этнически идентифицируемую часть регионального рынка, т.е. географическое пространство, на котором действуют рыночные субъекты коренного населения (представляющие сторону предложения, а, зачастую, и спроса), и имеют место соответствующие сегменты. При этом учитываются экономические, демографические, политические, социальные и другие условия функционирования данного пространства. Территориальное пространство этнорынка обычно не превышает размер основной административно-территориальной единицы рассматриваемой страны (область, округ, регион, штат). Но может ограничиться территорией города, поселка, городского района и т.п.

Проблемы функционирования этнических рынков рассматриваются в современной российской литературе, и ряд исследователей уделяют внимание именно таким рынкам. Так, Дятлов В.И. и Григоричев К.В., исследующие проблематику китайских и корейских этнорынков на Дальнем Востоке, пишут, что их можно считать стержневым элементом этнокластеров. 
Этнические рынки, по мнению этих авторов, стали играть важную экономическую, социальную и даже символическую роль в городском пространстве. Они быстро переросли простой формат торговых площадок и превратились в сложные и саморазвивающиеся социальные организмы, сгустки социальных связей, сетей, конфликтов, механизмов власти и контроля [2, c.35-37].

Характерные черты локального этнического потребительского рынка можно дифференцировать как общие и специфические. К числу общих правомерно отнести: спрос и предложение на рынке, объемы продаж, уровень жизни населения, его доходы, уровень и соотношение цен, размеры экспорта и импорта потребительских товаров, развитие инфраструктуры рынка и др. Специфические черты отражают различные грани особенностей локальных рынков: этно-исторические, национально-демографические, природно-климатические, геополитические, территориальные, ресурсные. В значительной степени их функционирование предопределяется этническими традициями, характером воспитания населения, его миграционной подвижностью и т.д. В этой связи, этнический рынок правомерно определить как систему товарно-денежных отношений, включающую этнические акторы (значимые субъекты, играющие важную роль в функционировании этносистем), а также продвигаемые на рынок товары и услуги, имеющие этнические особенности, соответствующую данному рынку инфраструктуру, визуальные презентации, и, при этом,- информацию, отражающую и характеризующую присущие им особенности.

В теории и практике современной региональной экономики локальный этнорынок трактуется как определенная этнически идентифицируемая подсистема хозяйствования, имеющая «сквозное» строение, которое в своих границах интегрирует макро,- мета-, мезо- и микроэкономические уровни производства и потребления [3, с. 57-82.].

Основными критериями выделения категории этнорынка, согласно принятой авторами трактовке, являются территория, этнокультурная среда и специализация. Они, во многом, предопределяют специфику этнорынков [4, с. 1105-1109].

- Так, территория предопределяет физический формат и границы рынка, его географиче- ское положение. Ее оценка позволяет с большей или меньшей точностью выявить количество проживающего населения, особенности природно-климатических факторов, экологическую обстановку, позиции пограничного (или внутреннего) положения по отношению к другим странам и регионам, имеющуюся транспортную инфраструктуру и проч.

- Этнокультурная среда отражает культурные, религиозные, национальные и иные особенности, в т.ч. традиции, обычаи, подходы к воспитанию молодого поколения, учитывающие этнические принципы, распространяющиеся на народонаселение локальной территории. Они, несомненно, влияют на производство товаров и услуг, обусловливают поведение потребителей данного этнорынка, выступают в качестве важнейшего аспекта целесообразности входа и присутствия на нем производителей товаров и услуг этнической оринетации, розничных торговых посредников, продавцов, организаторов перевозок товаров и др. участников рынка.

- Специализация определяет разновидность товаров (товарной группы) или услуг, которые предлагаются на данном рынке. Она диктуется как территориальными критериями, так и историческими предпосылками размещения этнопоселенческих пунктов, определенных производств и рыночной инфраструктуры. Сформировавшаяся специализация в настоящее время поддерживается странами и регионами как своего рода «торговая марка». Такими примерами на Северном Кавказе могут быть кубачинские изделия из серебра, кавказские минеральные воды, адыгейский сыр и др.

Выявление тенденций развития этнорынков свидетельствует о том, что их расширение, или, наоборот, «сжатие» зависит от некоторых факторов, в числе которых следующие:

- общая социально-экономическая ситуация, развитость рыночных отношений в стране и регионах, в целом;

- геополитическое положение и позиции конкретной территории;

- концентрация на определенной территории населения, имеющего в своих потребительских предпочтениях этноориентированные установки, запросы, потребности;

- наличие производителей товаров и услуг, способных удовлетворять такие потребности и поддерживающих сооветствующую рыночную среду; 
- насыщенность территории (в т.ч. при компактном проживании на ней населения, имеющего этноориентированное поведение) рынками (как местами торговли), а также магазинами с филиально-сетевыми структурами, составляющими конкуренцию местным продавцам, в значительной мере, «нивелирующими» местное товарное предложение, и способствующими, при этом, сужению пространства этнорынков потребления [5, с. 70-73].

В реальной экономике местные компании зачастую используют выбранный локальный рынок как стартовый, и если их продукция пользуется спросом и объемы продаж растут, быстро расширяют сферу продаж на рынки других регионов, а в дальнейшем и стран. Тем не менее, часть из них в силу различных обстоятельств не продвигается дальше локального уровня. Но это не будет означать, что такие производства убыточны или не имеют перспектив на рынке - присутствие и четкая ориентация на данный рынок является стратегической целью таких производителей. Это свидетельствует о том, что помимо крупных транснациональных и российских производственных компаний и поставщиков, действующих на потребительском рынке, существуют локальные компании, конкурентные стратегии которых в перспективе нацелены на сохранение рынка или, при возможности, расширение своего присутствия.

Субъектная определенность: участники этнических рынков. Участниками этнического рынка выступают, с одной стороны, потребители товаров, предъявляющие спрос на продукцию, реализуемую на такого рода рынках, а с другой ее производители и продавцы, заинтересованные в продаже товаров, продвигаемых на целевые сегменты рынка.

Для понимания особенностей этнорынков и поведения на них всех участников, целесообразно последовательно проанализировать потребителей и производителей, поставляющих на рынки этноориентированные товары, а также их конкурентов, партнеров и т.д. С этой целью возможно использование мезоэкономического анализа. Он предполагает составление представления о регионе, в границах которого развивается конкретный этнорынок, а также об отраслях и компаниях, малых предприятиях и индивидуальных хозяйствах, участвующих в его формировании, об инфраструктуре, логистике и др.

Потребители, ориентированные на тради- цционные продовольственные товары. В рамках выполнения Гранта «Хозяйственные практики народов Северного Кавказа: этноэкономика век XX1» авторами был проведен анализ потребителей данного макрорегиона, выступающих одной из сторон этнорынков, локализующихся на его территории. При этом выявлены особенности потребительского поведения, возможности и факторы развития такого рода рынков, на которых продаются товары, востребованные покупателями, имеющими специфические вкусы, запросы, пристрастия [6, с.116-121].

Для дополнения проведенного таким образом маркетингового анализа необходимым представляется, как подчеркивает Березин И.С., изучение потребителей, как носителей общих социальных признаков, образующих определенный сегмент рынка [7, с.19].

\section{2. Ориентация этнорынков регионов} Юга России на удовлетворение спроса целевых аудиторий потребителей

В формате изучения влияния этнорынков на удовлетворение потребностей населения конкретных регионов, в частности, в связи с компактным проживанием в них коренных народностей и этнических групп, продолжается дискуссия о природе этноса (от греч. ethnos народ, племя). Его, как правило, характеризуют как устойчивую совокупность людей, объединенных общими объективными или субъективными признаками [8]. Одним из обсуждаемых в этой дискуссии вопросов является такой, как: существует ли этническая группа объективно или является субъективно сформированным образованием, выступая в качестве определенного образа самоидентификации.

В значительной части монографий и статей высказывается утверждение о том, что этногруппа рассматривается как часть сообщества, способная к самоорганизации для взаимодействия с обществом и государством на альтернативной или дополняющей основе. Ее члены воспринимают отличительные признаки в качестве объединяющей платформы и утверждают тезис относительно общего происхождения или общей истории. Этногруппа отличается аскриптивными признаками - общим языком, культурой (письменность, праздники, обычаи, религия и др.), цветом кожи людей, их географическим местом рождения и, как правило, проживания. Эти признаки выступают в качестве 
этнокорпоративных стереотипов и находятся вне индивидуального контроля. В авторском понимании этнические группы существуют объективно, отражая разнообразие проживающего в современных условиях населения.

Потребительское поведение этногрупп включает в себя осознание присущих им потребностей, интересов, финансовых возможностей осуществления покупок, способы их выбора, а также торг, обслуживание потребителей, использование купленных товаров. Оно предполагает многократное повторение данного цикла применительно к разным товарам и в различное время. Анализ потребительского поведения предполагает обозначение конкретного рынка товаров и услуг. С учетом этого, этнорынок представляет собой форму социального взаимодействия между продавцом и покупателем, «окрашенную» особенностями потребительских предпочтений. Одной из структурных площадок, на которых это происходит, является рынок потребительских товаров и услуг, который и является сферой изучения специфики потребительского поведения.

Первоначально для исследования потребительского поведения с позиций маркетинга было характерно фокусирование внимания на отдельном индивиде-потребителе. Потребности клиента рассматривались как врожденные, а не сформированные обществом или рынком, поэтому перед фирмами ставилась задача «поймать потребителя на крючок», предлагая товары или услуги, удовлетворяющие его потребности лучше, чем то, что предложено конкурентами [9, с. 84]. Позже понимание групп потребителей значительно расширилось, в т.ч. за счет введения понятия «целевые аудитории» [10, с.292].

В последние годы признание тенденции к сохранению и развитию этнической самоидентичности населения нашло отражение и в потреблении. Это проявляется в том, что все более заметно стремление части населения демонстрировать в потреблении свою этническую принадлежность. При этом. возрождаются забытые атрибуты традиционной культуры, а также появляются новые, вводимые в современную моду.

Наступление эпохи постфордизма, характеризующегося господством гибких технологий, позволяющих выпускать продукцию мелкими партиями без ущерба для цены, материально подкрепило тенденцию ухода от стирающего этнически-обусловленные границы массового потребления. Во многих странах стал развиваться бизнес, связанный с культивированием у потребителей тяги к символам этнической принадлежности (национальные блюда, элементы традиционной одежды, ковры, ремесленные сувенирные изделия и т.п.). Если эта тенденция будет усиливаться, то роль этнического фактора в потреблении также будет возрастать [11, p.21-40]. Для маркетологов этническая пестрота потребителей означает изменение сегментации рынка, выделение новых целевых аудиторий. Каждая этническая группа выступает как особый сегмент, предъявляющий специфический спрос, удовлетворение которого может приносить немалую прибыль[12, р.204-205].

В целом, правомерно заключить: наличие этнокультурной мотивации поведения потребителей из числа четко выделяющихся этногрупп, очевидно. При доминировании массовой (не акцентированной) культуры потребления у значительной части населения мира, в целом, и России, в частности, именно ориентированность на этническую самоидентичность имеет тенденцию к усилению в многонациональных регионах. Одной из таких территорий являются регионы Юга России, в частности, Северного Кавказа.

В современном административно-территориальном состоянии республики, в которых проведено исследование, представляют собой регионы, входящие в состав Северо-Кавказского федерального округа (кроме них, в округ входит также Ставропольский край). Эти республики следующие: Республика Дагестан, Республика Ингушетия, Кабардино-Балкарская Республика, Карачаево-Черкесская Республика, Республика Северная Осетия-Алания, Чеченская Республика. Кроме того, в число кавказских республик нередко включают Республику Адыгею, входящую в Южный федеральный округ [13, с. 18-238].

Общие тенденции развития демографического потенциала республик Северного Кавказа, которые. во многом, отражают специфику целевых аудиторий потребителей, можно сформулировать следующим образом:

1. Высока доля населения, имеющего высшее образование $-31,5 \%$, при том, что среднее профессиональное образование имеют 28,7\%, среднее общее -20,8\% [13, с.155-192]. Это подтверждает стремление населения республик Северного Кавказа иметь достаточно высокий уровень образования, которое здесь весьма ценится. 
2. Велика доля населения молодых возрастов - удельный вес населения моложе трудоспособного возраста - 26, 2\%, что существенно выше, чем по России, в целом. (Для сравнения, в регионах соседнего Южного федерального округа доля детей и подростков составляет только 17,1\%). Удельный вес населения в трудоспособном возрасте значителен - 58,7\%, а старше трудоспособного, наоборот, относительно мал 15,8\%. В Южном же федеральном округе, в целом, доля пенсионеров, например, превышает 26,7\% [13, с.45-52].

3. Среднедушевые денежные доходы населения республик существенно ниже, чем по Российской Федерации, в целом (по РФ они составляют более 34,0 тыс. руб. в месяц) [13, с. 228-276]. Так, в Республике Ингушетии расходы на душу населения составляют 15,6 тыс.руб. в месяц, в Карачаево-Черкесской Республике - около19тыс.руб., что является одними из самых низких показателей в России. (При этом, речь идет только об учтенных доходах).

4. Сформулированные выше две позитивные тенденции относительно образовательного и возрастного состава населения республик Северного Кавказа (относительно высокая доля населения, имеющего высшее и среднее образование и более молодое по возрасту население), к сожалению, сопровождается высоким уровнем безработицы на Северном Кавказе - до 5-8\%, особенно, в Республике Ингушетия (до 15,7\%), и Чеченской Республике. Это одни из самых высоких показателей в стране. Однако, следует отметить изменение положение к лучшему. Например, в начале двухтысячных годов безработица в этих регионах достигала $30 \%$ и более. В последние же годы в регионе, в частности, в Чеченской Республике, введено в строй большое число предприятий в сфере перерабатывающей, домостроительной и др. отраслей промышленности, а также сельского хозяйства и строительства. Это обеспечило реальный рост числа рабочих мест, снижение безработицы, рост доходов.

При этом, высока доля занятого населения, работающего в секторе полунатурально-домохозяйственного уклада.

Такой уклад относится к традиционному архаичному типу хозяйствования, преобладающему в этноэкономическом сегменте хозяйственных комплексов ряда национальных республик Северного Кавказа и Нижнего Поволжья. Субъектами этого уклада являются домохозяйства автохтонных этносов, проживающих в горных и предгорных местностях, с низким экономическим потенциалом и невысоким уровнем рыночной освоенности [5, с.74-75]. Эта особенность организации производства, в частности, продуктов питания, предопределяет наличие большого числа локальных продовольственных рынков.

В такой ситуации превалирует тенденция продажи значительных объемов продовольствия в небольших магазинах, лавках и в рыночных павильонах, особенно, в сельской местности. Сетевые торговые структуры не получили здесь значительного распространения, вследствие чего. сохраняется локальная продажа мясных и молочных продуктов, овощей, фруктов, выпечки. Так, объем продажи товаров на розничных рынках и ярмарках в регионах Северного Кавказа в 2016 г. составлял свыше 425 млрд. руб., [13, с. 904-1034], и размеры таких продаж растут.

Вышеперечисленные тенденции, сложившиеся в экономической деятельности анализируемых республик, в немалой степени, предопределяющие специфику хозяйственно-бытового уклада проживающего здесь населения и его потребительского поведения, дают основания для ряда выводов и обобщений.

Они изложены с учетом результатов опросов населения относительно потребления мясной и молочной продукции в двух республиках - Карачаево-Черкесии и Адыгее, осуществленных в апреле - июне 2017 г. Данные исследования были проведены, по существу, повторно. Результаты подобного же исследования были опубликованы в 2011 году [14, с.42-108]. Их анализ показал высокую схожесть в характере ответов.

Выявление особенностей спроса местного населения на мясо, молоко и продукты из них проводилось путем интервьюирования как покупателей (196 респондентов), так и 12 продавцов мясной и молочной продукции. Обобщение результатов опроса позволило сформулировать следующие особенности покупательского поведения, выявить роль этнорынков регионов Юга России в удовлетворении спроса целевых аудиторий потребителей.

1. Имеет место устойчивая ориентация на конкретные продукты. Так, потребители Карачаево-Черкесской Республики покупают мясные и молочные продукты практически ежедневно (61\% опрошенных). При этом, как выяснилось, покупатели приобретают, в основном, сырое охлажденное мясо у проверенных продавцов, что- 
бы быть уверенным в его качестве и свежести. При этом, некоторые потребители содержат мясной и молочный скот в собственном хозяйстве, что обеспечивает натуральное потребление их семьёй качественных домашних продуктов (более $20 \%$ опрошенных). Обобщение результатов опроса показало, что спрос на мясомолочную продукцию в торговой сети, например, Карачаево-Черкесии является стабильно высоким. В ассортименте анализируемых небольших торговых точек (магазины у дома, мясные лавки) присутствует сырое мясо халяль (говядина, баранина, конина), сырое молоко, полуфабрикаты (переработанные субпродукты, копченое и сушено-вяленное мясо). Предпочтения потребителей относительно мясной продукции одного из сел этой республики представлены в таблице.

В некоторых торговых точках республик Северного Кавказа продают готовые к употреблению продукты (домашняя колбаса из конины, хычины, манты и др.). Они также пользуются спросом как у местного населения, так и у туристов. Как показал анализ, ассортимент специфических молочных продуктов также достаточно большой: айран, каймак, домашняя сметана, рассольный сыр и др. По свидетельству продавцов, такая продукция пользуется неизменным спросом.

Удельный вес специфических национальных мясных и молочных продуктов в ассортименте всей продукции составляет, по словам опрошенных, от 40 до 65\%, что косвенно подтверждает стабильный спрос на данные продукты.

В Адыгее, например, высоковостребован- ными являются такие молочные продукты, как адыгейский сыр (куае), айран, копченый сыр, сливки, сметана.

2. Изучение ориентации потребителей на цену мясомолочной продукции показало, что в Карачаево-Черкесской Республике цена не является основным фактором при покупке. Правомерно сделать вывод о том, что производители данного локального рынка удерживают довольно низкие наценки на мясную и молочную продукцию. Многие из них ориентируются на конкретных, вплоть до лично знакомых, потребителей. Инфляционные процессы последних лет в экономике страны, конечно, привели к удорожанию продуктов питания. Вследствие этого реальный спрос на них снизился. Однако, в целом, ориентация на регулярное употребление мяса в рационе жителей республики осталась. В то же время, в Республике Адыгея приобретение мясных и молочных продуктов в последние 4 года сократилось более, чем на $20 \%$.

3. Культурно-нравственная составляющая образа жизни потребителей является очень важным фактором в потребительском поведении, в частности, сельских жителей Карачаево-Черкесской Республики. Приготовление и потребление пищи тесно связано с религиозными обычаями и традициями, и это обстоятельство строго учитывается производителями и продавцами реализуемых продуктов. Например, в мясных павильонах и магазинах сел республики практически невозможно увидеть в продаже свинину, так как по обычаям ислама это мясо запрещено употреблять мусульманам в любом виде [15]. При

Таблица. Распределение ответов на вопрос «Какую специфическую национальную мясную продукцию Вы потребляете?» респондентов, проживающих в с. Учкекен (Карачаево-Черкесская Республика),\%

\begin{tabular}{|c|c|c|c|c|}
\hline \multirow{2}{*}{$\begin{array}{c}\text { Распределение ответов } \\
\text { респондентов }\end{array}$} & \multicolumn{4}{|c|}{ Виды национальной мясной продукции } \\
\hline & Вяленое мясо & Сохта & Джерме & Къыймала \\
\hline \multicolumn{5}{|l|}{ По возрасту } \\
\hline - до 30 лет & 11 & 32 & 33 & 13 \\
\hline - от 30 до 45 лет & 30 & 29 & 22 & 26 \\
\hline - старше 45 лет & 59 & 39 & 40 & 61 \\
\hline \multicolumn{5}{|l|}{ По полу } \\
\hline - женщины & 41 & 45 & 42 & 38 \\
\hline - мужчины & 59 & 55 & 58 & 62 \\
\hline \multicolumn{5}{|l|}{ По доходу на семью } \\
\hline - менее 15000 руб. в мес. & 21 & 31 & 12 & 18 \\
\hline - от 15001 до 40000 руб. в мес. & 33 & 33 & 10 & 15 \\
\hline - более 40001 руб. в мес. & 15 & 18 & 14 & 11 \\
\hline
\end{tabular}

По данным анкетного опроса 164 потребителей мясомолочной продукции, проведенного авторами в с. Учкекен, Карачаево-Черкесская Республика (апрель-май 2017 г.) 
этом, большой популярностью пользуется говядина и баранина, обычно с пометкой «халяль», т.е. дозволенное шариатом (в данном контексте обозначает особый процесс убоя скота и не запрещенные мясные продукты). Слово «халяль» может являться даже составной частью названия магазина или торгового павильона на рынке или ярмарке.

4. Экологическая чистота продуктов питания является важным обстоятельством при покупке для большинства опрошенных потребителей. Именно этот фактор назвали в качестве важнейшего 59\% опрошенных. Информация, имеющаяся у покупателя по поводу места происхождения приобретаемой мясомолочной продукции, либо выращивание скота в личном подсобном хозяйстве, значительно повышает для него экологическую «привлекательность» и полезность мяса и молочных продуктов. Весьма важны также: санитарно-гигиеническая безопасность (42\% ответов), свежесть (38\%), отсутствие генетически-модифицированных добавок - например, в полуфабрикатах (14\%). Озабоченность части опрашиваемых потребителей Адыгеи проблемой ГМО, относительно которых действуют стандарты в каждой стране [16, с.127], подтверждает понимание населением Северного Кавказа значимости здорового образа жизни. Это актуализирует учет природохозяйственных факторов при организации производств на Юге России, внедрения природоохранных технологий в растениеводстве и животноводстве [17, c.359].

5. Потребительское поведение сельских жителей Карачаево-Черкесской республики отличается высокой степенью традиционности и незначительной готовностью к изменениям. Большинство покупателей постоянно ходят в один-два магазина или к ранее знакомым продавцам на рынке (82\% опрошенных). Вследствие этого, производителям и продавцам заранее известно, кто будет их покупателями. Большую долю в повседневном рационе населения занимают национальные мясные блюда (более 40\% опрошенных). Население Карачаево-Черкесии в возрасте старше 50 лет (особенно мужчины) охотно покупает специфические мясные продукты, в то время как молодые покупатели (возраст до 25 лет) к таким продуктам проявляют существенно меньше внимания.

Сформулированные особенности показывают, что почти все местные жители республик
Северного Кавказа придерживаются национальных традиций в питании. В связи с этим деятельность участников исследуемых локальных рынков характеризуется высокой степенью этноориентированности и замкнутости на внутренних поставщиков. Это является отчасти положительным фактором, но такая замкнутость дает слабый импульс для развития, к примеру, мясомолочного производства республик в существенно больших размерах, при имеющемся колоссальном ресурсном потенциале данных территорий.

Таким образом, исследование проблемы развития этнорынков в структуре экономического пространства регионов Юга России позволяет резюмировать его следующим образом.

1. Локальные этнорынки представляют собой рыночные сегменты национальной экономики, выделяемые по географическому, национально-этническому, товарному, функциональному и другим признакам, функционирование которых предполагает территориальную ограниченность, концентрацию на одном или нескольких сегментах, отличающихся этноэкономической спецификой. На локальных этнорынках действуют рыночные субъекты в рамках соответствующих сегментов, т.е. в отношении групп потребителей, одинаково реагирующих на один и тот же предлагаемый продукт и комплекс маркетинга. Оценивая имеющиеся в данной плоскости исследования, можно сделать заключение о том, что это - относительно новая, претендующая на самостоятельную область знаний, важнейшая сфера этноэкономических исследований, маркетинговых разработок, регионалистики, экономгеографии.

2. Изучение вопросов устойчивости наличия этнокультурной составляющей в потребительском спросе покупателей, проживающих в республиках Северного Кавказа, показало ее значимость. Особенно это присуще территориям, где компактно проживает население, имеющее устойчивую приверженность к определенным продуктам питания, видам и цвету одежды. Данная тенденция отчетливо проявляется, например, при потреблении мясомолочных продуктов, в частности, в регионах проживания населения, исповедующего ислам, иудаизм, буддизм. Это актуализирует вопросы ориентации этнорынков регионов, например, Юга России на удовлетворение спроса целевых аудиторий потребителей. При этом выявлено, что потреби- 
тельское поведение жителей Северного Кавказа неоднородно, оно различается в зависимости от места их проживания, сложившихся традиций, воспитания и т.д.

3. Проведенный анализ показал, что производители и поставщики продуктов питания чаще всего действуют в мультинациональной среде, в которой сильны локальные факторы, при существенном влиянии глобальной интеграции. Ключевым фактором успеха на таких рынках является адаптация производителей к местным условиям, учет вкусов и потребностей покупателей, во многом предопределяемых конкретной этнокультурной составляющей.

4. Оценка позиционирования этнорынков в структуре рыночно-экономического пространства регионов Юга России показала, что такого рода рынки повышают возможности локализации трудовой активности и коммерческой дея- тельности, в т.ч. в этноориентированном малом бизнесе, приближения его к локальным узлам трансакционной активности, стимулируя их ориентацию на удовлетворение спроса целевых аудиторий потребителей в конкретных регионах. Признание их специфики предполагает учет таких особенностей в моделях поведения компаний, ориентированных на максимальное удовлетворение покупательского спроса и повышение, при должном учете данного фактора, своей конкурентоспособности. Особенно значимо понимание значимости потребления населением специфических продуктов питания и готовых блюд кавказской кухни.

Статья подготовлена при поддержке гранта РФФИ (проект 18-010-00283 «Морфология экономического пространства региона: междисциплинарный подход»).

\section{Библиографический список}

1. Словарь терминов [Электронный ресурс]. Режим доступа: www.glossary.ru, свободный

2. Этнические рынки в России: пространство торга и место встречи: Монография / Науч.ред. Дятлов В.И., Григоричев К.В.- Иркутск: Изд-во ИГУ, 2015. 342с.

3. Гранберг А.Г. Региональная экономика и региональная наука в России: десять лет спустя// Регион: экономика и социология. 2004. № 1. С. 57-82.

4. Кетова Н.П., Овчинников В.Н. Этническая мотивация потребительского поведения покупателей на продовольственных рынках Северного Кавказа // Экономика и предпринимательство. 2016. № 8 (73). С. 11051112

5. етова Н.П., Овчинников В.Н. Институты развития в многоукладных экономиках периферийных регионов //Проблемы прогнозирования. 2014. № 2. С. 68-76.

6. Традиционные хозяйственные практики народов Северного Кавказа: этноэкономика - век XX1: Монография / Под ред. Колесникова Ю.С., Овчинникова В.Н. Ростов-на-Дону. 2017. 192с.

7. Березин И.С. Маркетинговый анализ. Рынок. Фирма. Товар. Продвижение. Москва. 2007. 480с.

8. ЭТНОС [Электронный ресурс]. Режим доступа: https://yandex.ru/search/?1r=39\&clid=2242347 \&text=\%D0\%AD \%D0\%A2\%D0\%9D\%D0\%9E\%D0\%A1, свободный

9. Ольсевич Ю. Хозяйственная система и этнос // Вопросы экономики. 1993. № 8. С.12-16.

10. Багиев Г.Л., Кетова Н.П. Маркетинг в отраслях и сферах деятельности. Санкт-Петербург.2016. 339с.

11. Glazer N., Moynihan D.P. (Eds.) Ethnicity: Theory and Experience. Cambridge, MA: Press \& Harvard University Press. 1975

12. Marketing in a multicultural world: ethnicity, nationalism, and cultural identity / Janeen Arnold Costa, GaryJ. Bamossy, editors. Thousand Oaks, Calif.: SAGE Publications, 1995

13. Регионы России. Социально-экономические показатели. 2017. Стат.сб. Москва. 2017. 1402с.

14. Кетова Н.П., Тимченко Е.Ю. Этномаркетинг как концепция деятельности компаний на локальных продовольственных рынках. Ростов-на Дону. 2011. 132с.

15. Халяль и нехаляль продукты [Электронный ресурс]. Режим доступа: http:/www.umma.ru/questions/halalproducts/, свободный.

16. Айзинова И.М. Проблемы продовольственной безопасности в сфере потребления: региональный аспект// Проблемы прогнозирования.-2015-№ 6. С 125-130.

17. Овчинников В.Н., Кетова Н.П. Природохозяйственные императивы структурной организации экономического пространства региона // Экономика и предпринимательство. 2018. № 9 (98).С.356-361. 
ЭКОНОМИКА. ЭКОНОМИЧЕСКИЕ НАУКИ

\section{ФИНАНСЫ, ДЕНЕЖНОЕ ОБРАЩЕНИЕ И КРЕДИТ}





\title{
СИСТЕМНЫЕ ПРОБЛЕМЫ НА ПУТИ ПОВЫШЕНИЯ ЭФФЕКТИВНОСТИ ПОСЛЕДУЮЩЕГО ВНУТРЕННЕГО ГОСУДАРСТВЕННОГО ФИНАНСОВОГО КОНТРОЛЯ
}

\author{
(C) 2018 Подкопаева Екатерина Вячеславовна \\ аспирант, кафедра государственных и муниципальных финансов \\ Санкт-Петербургский государственный экономический университет \\ Россия, 191023, Санкт-Петербург, ул. Садовая, д. 21 \\ E-mail: podkopaeva2006@rambler.ru
}

Статья посвящена изучению проблемы нехватки ревизорского состава Федерального казначейства, непосредственно осуществляющего функции последующего внутреннего государственного финансового контроля, а также проблеме транспарентности деятельности в рамках такого контроля. В статье проанализирована практика Федерального казначейства по применению риск-ориентированного подхода при планировании контрольных мероприятий. Представлена авторская позиция в отношении взаимосвязи объемов финансирования функции внутреннего государственного финансового контроля, кадрового голода, формализма и декларативной гласности в деятельности органа, осуществляющего функции последующего внутреннего государственного финансового контроля.

Ключевые слова: внутренний государственный финансовый контроль, Федеральное казначейство, последующий финансовый контроль, кадровый голод, транспарентность деятельности органа власти.

В 2016 году развитие внутреннего государственного финансового контроля (далее ВГФК) в России вступило в новый этап - указом Президента Российской Федерации Росфиннадзор упразднен, а его функции в рамках осуществления контрольно-надзорных полномочий в бюджетных правоотношениях переданы Федеральному казначейству. Функции и полномочия Федерального казначейства в сфере ВГФК после упразднения Росфиннадзора представлены в табл. 1.

Упразднение Росфиннадзора также преследовало долгосрочную цель - уменьшение числа государственных служащих органов государственной власти. Так, штатная численность Росфиннадзора в 2008 году составляла 6099 штатных единиц [5]. Однако после организационно-штатных мероприятий в 2012 [6] и 2015 [3] годов предельная штатная численность органа, осуществлявшего функции последующего ВГФК, сократилась на $30 \%$.

Вместе с функциями и полномочиями Росфиннадзора в 2016 году Федеральному казначейству передан только ревизорский состав упраздненной службы. Если в 2015 году в Федеральном казначействе функции по ВГФК осуществляло 368 человек [8], то уже в 2017 эта цифра составила 2326 штатных единиц [10], из которых фактическую численность составля- ло только 2100 человек [10]. Таким образом, на первый взгляд, пул ревизоров в Федеральном казначействе в 2016 году увеличился на 1958 штатных единиц. Однако следует учитывать, что в 2016 году штатная численность Росфиннадзора составляла 4794 единицы. То есть из общей штатной численности Росфиннадзора только 40\% кадрового состава в качестве ревизоров вошли в состав Федерального казначейства. При этом, о нехватке кадров говорил еще в 2011 году руководитель Росфиннадзора С.Ю. Павленко [6]. Вместе с тем, согласно доклада о результатах деятельности Федерального казначейства за 2016 год [9] происходит постоянное ежегодное увеличение объема контрольных мероприятий. Таким образом, очевидно, что при совокупности двух вышеуказанных факторов: увеличение объема работы и сокращении численности ревизорского состава, непосредственно осуществляющего контрольно-надзорные мероприятия в рамках функции ВГФК, повышается интенсивность работы ревизора, что, в случае недостатка финансирования, может привести к текучести кадров и, в итоге, к кадровому голоду.

Стремление к максимальной автоматизации работы ревизорского состава, безусловно, будет способствовать в будущем нивелированию проблемы нехватки кадров, но не разрешит ее. Это связано, прежде всего, не только с перманентно 
Таблица 1. Функции и полномочия Федерального казначейства после упразднения Росфиннадзора

\begin{tabular}{|c|c|}
\hline Функции Федерального казначейства & Передаваемые функции Росфиннадзора \\
\hline \multicolumn{2}{|c|}{ Предварительный контроль } \\
\hline $\begin{array}{l}\text { Контроль за: } \\
\text { - соответствием содержания проводимой операции } \\
\text { коду бюджетной классификации Российской Федера- } \\
\text { ции, указанному в платежном документе; } \\
\text { - наличием у получателя средств федерального } \\
\text { бюджета документов, подтверждающих, возникнове- } \\
\text { ние у него денежных обязательств } \\
\text { Контроль за: } \\
\text { - непревышением лимитов бюджетных обяза- } \\
\text { тельств, над утвержденными лимитами; } \\
\text { - непревышением бюджетных ассигнований, над } \\
\text { утвержденными бюджетными ассигнованиями; } \\
\text { - непревышением кассовых расходов, над доведен- } \\
\text { ными лимитами бюджетных обязательств и (или) } \\
\text { бюджетных ассигнованиями; } \\
\text { - непревышением кассовых выплат, над доведен- } \\
\text { ными бюджетными ассигнованиями. }\end{array}$ & $\begin{array}{l}\text { Контроль за соблюдением законодательства о кон- } \\
\text { трактной системе в сфере закупок, а именно за: } \\
\text { - за соблюдением требований к обоснованию заку- } \\
\text { пок; } \\
\text { - за соблюдением правил нормирования в сфере } \\
\text { закупок; } \\
\text { - за обоснованием начальной (максимальной) цены } \\
\text { контракта, включенной в план-график }\end{array}$ \\
\hline \multicolumn{2}{|c|}{ Последующий контроль и надзор } \\
\hline нет & $\begin{array}{l}\text { Контроль за: } \\
\text { - соблюдением бюджетного законодательства РФ; } \\
\text { - полнотой и достоверностью о реализации госу- } \\
\text { дарственных программ РФ; } \\
\text { - соблюдением законодательства о контрактной } \\
\text { системе в сфере закупок, а именно за: } \\
\text { * за применением заказчиком мер ответственности в } \\
\text { случае нарушения поставщиком условий контракта; } \\
\text { * за соответствием поставленного товара (работы, } \\
\text { услуги) условиям контракта; } \\
\text { * за своевременностью, полнотой и достоверностью } \\
\text { отражения в документах учета поставленного товара } \\
\text { (работы, услуги); } \\
\text { * за соответствием использования поставленного то- } \\
\text { вара (работы, услуги) целям осуществления закупки. } \\
\text { - использованием средств Фонда содействия рефор- } \\
\text { мированию ЖкХ, направленных на предоставление } \\
\text { финансовой поддержки } \\
\text { - за использованием региональным оператором } \\
\text { средств, полученных в качестве государственной } \\
\text { поддержки, муниципальной поддержки капитально- } \\
\text { го ремонта. } \\
\text { Кроме того: } \\
\text { - анализ исполнения бюджетных полномочий } \\
\text { органов государственного (муниципального) финан- } \\
\text { сового контроля, являющихся органами (должност- } \\
\text { ными лицами) исполнительной власти субъектов РФ } \\
\text { (местных администраций) } \\
\text { - анализ проведения главными администраторами } \\
\text { средств федерального бюджета внутреннего финан- } \\
\text { сового контроля и внутреннего финансового аудита. }\end{array}$ \\
\hline
\end{tabular}

Источник. Составлено автором.

меняющимся законодательством, но и с особенностью последующего ВГФК, который предполагает мероприятия по фактическому контролю расходов бюджетных средств с выездом на объект контроля и встречными проверками.

Вместе с тем, с учетом всё возрастающего объема контрольных мероприятий, в погоне за количественными показателями результатов деятельности, недостаток ревизорского состава неизбежно приведет к смещению акцента на проблему формализма, который, в свою очередь, может выражаться, как в подчеркивании непосредственных результатов деятельности (например, утверждение той или иной инструкции, методики, заключению формального соглашения и т.д.), так и отсутствии информации о каком-ли- 
бо показателе деятельности в открытых источниках.

Так, в рамках перехода к риск-ориентированному планированию контрольных мероприятий в 2016 году Федеральным казначейством утверждена Методика отбора контрольных мероприятий для формирования планов с учетом применения риск-ориентированного подхода [4] (далее - Методика 2016 года). При этом следует отметить, что аналогичная Методика отбора контрольных мероприятий была утверждена еще приказом Росфиннадзора в 2014 году [8].

Исходя из основных направлений деятельности Федерального казначейства на среднесрочную перспективу [10] план контрольных мероприятий на 2018 год формировался на следующих основаниях (см. табл. 2).

Согласно Методике 2016 года, при формировании плана контрольной деятельности на очередной год в первую очередь включаются контрольные мероприятия, в отношении которых поступили поручения Президента Российской Федерации, Правительства Российской Федерации, Министерства финансов Российской Федерации, правоохранительных органов, депутатские запросы, обращения члена Совета Федерации или депутата Государственной Думы, комитетов и комиссий палат Федерального Собрания Российской Федерации.

При этом, согласно итоговому докладу Федерального казначейства в 2016 году [9] произошло резкое увеличение внеплановых контрольных мероприятий по запросам правоохранительных органов и Министерства финансов.

Таким образом, применение риск-ориентированного подхода, в данном случае, сводится к включению в план проверок по обращениям Министерства финансов РФ и правоохранительных органов, что, не нарушая Методики 2016 года, в свою очередь является признаком формализма, поскольку применение риск-ориентированного подхода, в первую очередь, предполагает отбор контрольных мероприятий на основе анализа рисков.

Кроме того, одной из особенностей 2016 года явилось увеличение доли проверок по централизованным заданиям (т.е. заданиям центрального аппарата Федерального казначейства - прим. автора), осуществляемых территориальными органами Федерального казначейства [9]. Такие централизованные задания доводятся до территориальных органов Федерального казначейства без учета информации о контрольных мероприятиях в предыдущие годы, в результате чего, одни и те же направления подвергаются проверкам из года в год, в связи с чем, результативность проведения контрольных мероприятий по централизованным заданиям значительно ниже.

Таким образом, при формировании плана контрольной деятельности территориальные органы Федерального казначейства, в обязательном порядке, включают в план проверки по обращениям правоохранительных органов, Министерства финансов РФ, по централизованным заданиям. И только после этого территориальный орган Федерального казначейства может включить в план те проверки, которые могут быть отнесены им к риск-оправданным с точки зрения риск-ориентированного подхода. А при ограниченности трудовых ресурсов включение в план таких проверок, очевидно, будет сводиться к минимизации.

Отсюда следует, что в стремлении получить положительную оценку своей деятельности орган ВГФК при подготовке отчетов и докладов о широком применении риск-ориентированного подхода при формировании планов контрольно-надзорной деятельности, допускает долю популизма.

С целью повышения качества контрольно-надзорных мероприятий, а также сокраще-

Таблица 2. Основания для формирования плана контрольных мероприятий Федерального казначейства на 2018 год

\begin{tabular}{|l|c|}
\hline \multicolumn{1}{|c|}{ Основания для включения в План } & Количество пунктов Плана \\
\hline Поручения Министерства финансов Российской Федерации & 46 \\
\hline Предложения структурных подразделений ЦАФК & 42 \\
\hline Обращения Федеральной службы безопасности Российской Федерации & 5 \\
\hline Обращения Генеральной прокуратуры Российской Федерации & 2 \\
\hline Иные основания & 69 \\
\hline Итого: & \\
\hline
\end{tabular}

Источник. Составлено автором. 
нию количества судебных исков по результатам проверок, в центральном аппарате и в территориальных органах Федерального казначейства созданы контрольные комиссии, на заседаниях которых рассматриваются результаты контрольных мероприятий с обязательным приглашением для участия в них руководителей объектов контроля [11].

Такой подход к процедуре реализации материалов проверок, с одной стороны, дал толчок развитию досудебного порядка обжалования результатов ВГФК: на заседаниях контрольных комиссий объекты контроля имеют возможность высказать свои возражения и представить дополнительные объяснения до обращения в суд. С другой стороны - такой механизм публичности рассмотрения результатов проверок и коллегиальность принятия решения позволяет говорить о попытке прийти к транспарентности деятельности органа ВГФК. Однако, пока эта «открытость» является только «открытостью» для самих органов ВГФК и для конкретного объекта проверки, говорить о прозрачности результатов деятельности органа ВГФК для широких масс населения страны не приходится. Так, сайт Федерального казначейства, действительно содержит информацию о показателях деятельности органа ВГФК. Вместе с тем, информация о конкретных «нарушителях» бюджетного законодательства, а также о суммах, возмещенных в бюджет конкретными лицами, на сайте отсутствует. Такая информация об отдельных случаях, которые могут вызвать общественный резонанс, в официальных источниках не размещается. При этом информация о результатах деятельности органа ВГФК размещается в форме докладов или диаграмм, в которых уже проведен анализ по отдельным показателям, не предоставляя полной информации о всех показателях, что не позволяет сделать сравнительный анализ самостоятельно, ввиду отсутствия тех или иных данных в ретроспективе.

Решение проблемы закрытости информации о результатах деятельности органов, осуществляющих последующий ВГФК, путем размещения информации на официальном сайте такого органа, в итоге сводится к наполнению сайта разрозненными несопоставимыми в ре- троспективе цифрами и выводами о результатах деятельности, сделанными самим органом ВГФК [11].

Резюмируя, следует констатировать, что гласность результатов контрольно-надзорной деятельности по-прежнему остается гласностью декларативной.

Таким образом, на сегодняшний день органу государственной власти, осуществляющему функции ВГФК, как и в предыдущие периоды развития нашего государства [7], присущи одни и те же проблемы повышения эффективности деятельности: нехватка кадров, формализм и закрытость результатов деятельности.

Изложенное свидетельствует о наличии системного недостатка, влекущего за собой вышеперечисленные проблемы.

Так, в 2015 году на содержание Росфиннадзора из федерального бюджета выделено 3 млрд. 596 млн. 749 тысяч рублей [8]; на содержание Федерального казначейства - 34 млрд. 613 млн. 908 тысяч рублей [8]. После передачи функций Росфиннадзора в сфере ВГФК Федеральному казначейству объем финансирования последнего в 2017 году составил 38 млрд. 117 млн. 391 тысяч рублей [2]. Увеличение объема финансирования составило $10,1 \%$.

Недостаток финансирования, как показывает история развития государственного финансового контроля в России, является системным недостатком. И решение отдельных проблем, вытекающих из него, может привести только к эпизодичному улучшению эффективности деятельности органов, государственный финансовый контроль, до тех пор, пока не произойдет смещение акцента к той или иной вышеуказанной проблеме.

Таким образом, решение проблемы эффективного ВГФК путем нивелирования проблемы нехватки кадров, формализма или закрытости информации о результатах деятельности, дает только временный эффект до того момента пока не будет устранен системный недостаток - недостатков финансирования функции ВГФК, результатом которого являются все вышеперечисленные проблемы повышения эффективности ВГФК.

\section{Библиографический список}

1. Бюджетный кодекс Российской Федерации - [Электронный ресурс] - Режим доступа: http://base.consultant. ru. 
2. Федеральный закон от 19.12.2016 № 415-Ф3 «О федеральном бюджете на 2017 год и на плановый период 2018 и 2019 годов» - [Электронный ресурс] - Режим доступа: http://base.consultant.ru.

3. Постановление Правительства Российской Федерации от 11.12 .2015 № 1353 «О предельной численности и фонде оплаты труда федеральных государственных гражданских служащих ...» - [Электронный ресурс] Режим доступа: http://www.consultant.ru.

4. Приказ Федерального казначейства от 30.12.2016 № 532 «Об утверждении методики отбора контрольных мероприятий при формировании планов контрольных мероприятий Федерального казначейства и территориальных органов Федерального казначейства в финансово-бюджетной сфере» - [Электронный ресурс] - Режим доступа: http://base.consultant.ru.

5. Павленко С.Ю. Итоги работы Росфиннадзора за 2005 год. Направления деятельности службы на 20062008 год. Интернет-конференция. 2006. - [Электронный ресурс] - Режим доступа: http:// www.garant.ru/ interview/10113/.

6. Павленко С.Ю. Итоги деятельности Федеральной службы финансово-бюджетного надзора в 2010 году и приоритетные задачи на 2011 год (интернет-конференция) // Бюджетная политика. 2011. № 13. Стр. 21-31.

7. Подкопаева E.В. Генезис внутреннего государственного финансового контроля в России // Финансовая экономика. 2018. № 4 (ч. 2). Стр. 231-236.

8. Годовой отчет Министерства финансов Российской Федерации за 2015 год (уточненный) о ходе реализации и оценке эффективности реализации государственной программы Российской Федерации «Управление государственными финансами и регулирование финансовых рынков» - [Электронный ресурс] - Режим доступа: http:// special.minfin.ru/ru/document/?id_4=114007.

9. Итоговый доклад о результатах деятельности федерального казначейства за 2016 год и основных направлениях деятельности на среднесрочную перспективу - [Электронный ресурс] - Режим доступа: http://www. roskazna.ru/o-kaznachejstve/plany-i-otchety/?year=2017.

10. Итоговый доклад о результатах деятельности федерального казначейства за 2017 год и основных направлениях деятельности на среднесрочную перспективу - [Электронный ресурс] - Режим доступа: http://www. roskazna.ru/o-kaznachejstve/plany-i-otchety/?year=2018

11. Официальный сайт Федерального казначейства - [Электронный ресурс] - Режим доступа: http:// roskazna. $\mathrm{ru}$. 


\title{
ДЕДОЛЛАРИЗАЦИЯ МИРОВОЙ ЭКОНОМИКИ КАК ФАКТОР ПРОТИВОДЕЙСТВИЯ АГРЕССИВНОЙ ПОЛИТИКЕ США
}

\author{
(c) 2018 Ливенский Валентин Михайлович \\ доцент кафедры финансов \\ Полесский государственный университет \\ 225710, Республика Беларусь, г. Пинск, ул. Днепровской флотилии, 23 \\ E-mail: livey@tut.by
}

В статье анализируется внешняя политика США, стремясь сдерживать развитие стран, которые они считают своими конкурентами на мировых рынках; обосновывается тот факт, что ряд ведущих стран в ближайшем будущем, предвидя негативные последствия для мировой экономики, будут проводить политику дедолларизации своих экономик.

Ключевые слова: мировая экономика, торговые войны, санкции, кризис, дедолларизация экономик.

Сегодня ряд ведущих экспертов, в том числе и в самих США, уже проводят параллели между текущей ситуацией и периодом до Второй мировой войны. Тем более, что в американской истории уже были примеры торговых войн с применением санкций, импортных пошлин, пересмотра существующих соглашений и договоров [1].

И хотя, как известно, исторические процессы никогда не повторяются с абсолютной точностью, тем не менее, многие действия администрации Трампа и его идеологическая риторика говорят в пользу того, что во внешней политике США вновь возвращаются к смеси изоляционизма и империализма, стремясь «сдерживать» развитие стран, которые они считают конкурентами на мировых рынках и «угрозой для национальных интересов» [2].

Есть ещё один фактор, который заметно поменялся по сравнению с тем, что было лет 10 назад. Это Китай и его отношения со своими партнёрами, которые приобрели в глобальном пространстве заметно большее значение. Сегодня это вторая по величине экономика в мире с постоянно растущими запросами, которая выстраивает свои партнёрские отношения без оглядки на США. Поэтому соперничество с Китаем будет одним из наиболее важных факторов для мира в последующие 10 лет. Применим здесь концепцию под названием «ловушка Фукидида», которая свидетельствует, что растущая держава всегда ведёт соперничество с существующей державой и вероятность войны повышается. Данный постулат сработал 16 раз за последние 500 лет - во всех подобных случаях происходили войны [3].
Это не значит, что войны сейчас будет не избежать. Но это означает, что соперничество между странами и их близкими партнёрами, которое начинается в экономической сфере, может стать политическим и военным. Тем более, что экономика Китая, если не остановить её текущее бурное развитие, будет существенно больше экономики США уже через 20 лет. Поэтому здесь пока присутствует «мягкое соперничество». Мы пока находимся на раннем этапе этих процессов, которые в скором времени определят, как это соперничество будет развиваться в ближайшем будущем [4].

Но что мы уже наблюдаем сейчас? Напряжённость усиливается по всем направления, по мере того как Китай, Россия, Иран, Турция и другие страны устанавливают многополярный мировой порядок. США отвечают этому вызову - на фоне агрессивного настроя американского истеблишмента стала усиливается военная и экономическая напряжённость. И уже довольно сложно остановить смещение мирового порядка в сторону однополярной системы управления и это заставляет государство США использовать любой вид оружия для достижения своих целей, при этом неважно, каковы будут последствия подобной безрассудной внешней политики США для всего остального мира.

Приведём ряд конкретных примеров. В то время, когда провинция Идлиб в шаге от освобождения от террористов Сирийской Арабской армией (SAA), усиливается напряжённость между США и Сирией (и союзниками Сирии). Кажется, что каждую значительную военную кампанию SAA сопровождают ложные сообщения западных СМИ и правительств, предупреждающих о 
неминуемом использовании химического оружия SAA. Напряжённость растёт и потому, что президент выразил желание нанести удар по Сирии из-за предполагаемого использования химического оружия, и это даже без проведения какой-либо независимой проверки. Угрозы США, Великобритании и Франции, заявляющих о бомбардировке российских войск в Сирии, ежедневно и с искажением озвучиваются в западных СМИ. Это безумие достигло уже совершенно невероятных уровней.

События в Сирии, похоже, сопровождаются настойчивыми попытками Украины и США саботировать минские соглашения, разжечь заново конфликт, чтобы обвинить в этом Россию.

Ещё более фальшивые обвинения против Москвы в отравлении бывшего российского шпиона Сергея Скрипаля в Великобритании вышли после обвинений Москвы о вмешательстве в президентские выборы в США.

К накаляющейся ситуации можно добавить и постоянные угрозы, наряду с экономической и финансовой войной, посылаемые в адрес Ирана Израилем, Саудовской Аравией и США, претензии разного рода США к Турции [5].

Неудивительно, что в таком контексте Российская Федерация только что провела самые крупные военные учения за всю свою новую историю. Не следует удивляться тому, что и Китай направил тысячи солдат для участия в этих учениях, заставив обратить на это внимание Вашингтон и Запад.

Осенний Восточный экономический форум во Владивостоке является ещё одним важным моментом в новой китайско-российской стратегии, цель которой состоит в том, чтобы ограничить и, по возможности, изолировать хаос, вызванный США, поддержать страны, которых коснулось влияние Вашингтона, и расширить сотрудничество во всех возможных направлениях.

Экономические связи между производственными китайско-российскими системами двух стран заслуживают сейчас особого внимания и это партнёрство выходит далеко за пределы России и Китая. Технологическое сотрудничество расширяется в таких регионах, как Африка и Юго-Восточная Азия, предлагая важные соглашения с третьими странами. Специализацией Москвы является продажа ядерной энергии и оружия, в то время как щедрые кредиты и совместная разработка основных ресурсов - приоритет Пекина. Такие предложения помощи важны не только для стран третьего мира (Китайско-российские действия в Африке постепенно разрушают структуру западного неоколониализма), стремящихся освободиться от колонизации Запада, но также и для тех стран, которым необходим новый многополярный мировой порядок. Действительно, стратегический квадрат между Тегераном, Турцией, Пекином и Москвой вовлекает все соседние страны в большой геополитический вальс. А создание альтернативной системы SWIFT сможет снизить централизованную роль американских банковских учреждений и политический вес доллара США.

Как видим, в целом многополярный порядок международных отношений уже развивается на обширных территориях планеты как с военной, так и с экономической точек зрения. Дедолларизация при этом - это неизбежный этап для достижения значительного экономического суверенитета [6]. Как видим, Китай, всё более поддерживаемый Россией, предпринимает решительные шаги для создания жизнеспособной альтернативы тирании доллара США в мировой торговле и финансах. Уолл-стрит и Вашингтон не удивлены этому, но остановить это они не в силах, пишет американский экономист Фредерик Уильям Энгдаль [7].

На этом фоне логика недавнего введения тарифов на китайскую продукцию на сумму более \$200 млрд. больше похоже на шаг отчаяния. Даже исторические союзники США - Южная Корея, Пакистан, Индия и Турция - не раз подчёркивали, что опасаются иррациональности Вашингтона и политики «Америка прежде всего» и ищут пути, чтобы включиться в обширный евразийский континент и участвовать в экономических и финансовых форумах для диверсификации финансирования и сотрудничества на промышленном уровне.

Завершает эту картину внутренняя экономическая борьба: европейские союзники вынуждены страдать от огромных экономических потерь в результате санкций против России, Китая и Ирана. Торговые тарифы, особенно в таких странах, как Турция, Япония и Южная Корея, заставляют союзников США изучать альтернативы с точки зрения доверия и сотрудничества.

Европейский истеблишмент в некоторых западных странах, таких как Германия, Франция и Великобритания, похоже, решил пока переждать. Но многие интуитивно поняли, что на самом деле происходит в западном мире. Известные 
лидеры начинают предпринимать серьёзные шаги для изучения возможных альтернатив союзу с США.

Вашингтон встречает все эти сценарии со скептицизмом, досадой и отвращением, опасаясь потерять важные страны и способность устанавливать региональное равновесие на планете. И многих аналитиков удивляет сегодня упрямство и глупость американских политиков. Чем больше они пытаются сохранить однополярный порядок в США, тем больше стимулов они дают другим странам развивать многополюсную систему. Но США по-прежнему сохраняют дипломатическое высокомерие и стратегическую глупость.

И каждый сценарий, связанный с США, теперь необходимо рассматривать с учётом двух факторов: попытки сохранить империалистическую позицию и внутренней борьбы с элитами. А нынешняя макроэкономическая среда всё больше напоминает ситуацию 1930-х гг. Кроме того, прошлый опыт особенно актуален сегодня, так как это был один из периодов, когда ряд крупных экономик столкнулись с проблемой 3Д (долга, демографии и дефляции). Действительно, непродуктивное накопление долга стало причиной как Великой депрессии 1930-х гг., так и Великой рецессии 2008-2009 гг. Кроме того, более слабые демографические тенденции в ряде стран в течение обоих периодов времени также оказывали негативное влияние на потенциальный рост. Падение частного спроса в связи с последующим процессом сокращения доли заёмных средств создало интенсивное дефляционное давление.

Таким образом, как утверждают аналитики банка Morgan Stanley, ситуация конца 30-х гг. сейчас может повториться. Однако здесь стоит учитывать, что после повторения кризиса 30-х гг. экономика США восстанавливалась очень медленно, к более быстрым темпам роста она перешла только после начала Второй мировой войны. Дело в том, что военные расходы являются одним из основных источников роста экономики США. Этот факт ещё совсем недавно повторил бывший глава ФРС Бен Бернанке на панельной сессии «тhe defense economy and American prosperity» («Военная экономика и процветание Америки»), организованной Брукингским институтом (Brookings Institution) в конце 2015 г. И если ситуация всё же будет повторяться, то не исключено, что США понадобится очередная масштаб- ная война, которая будет способна вытащить экономику страны из затяжного пике [8].

Но что же США делать с наметившейся дедолларизацией? Ибо если раньше господство доллара сохранялось, не тая в себе смертельной угрозы, то в последнее время ситуация резко изменилась к худшему. До тех пор пока грязные трюки и махинации Уолл-стрит провоцировали кризисы, страны с профицитом торгового баланса, такие как Китай, Япония, а затем и Россия, не имели альтернативы, кроме как постоянно скупать трежерис США. Вашингтон и Уолл-стрит могли печатать бесконечные объёмы долларов, ничем более ценным не поддерживаемые, кроме как истребителями F-16 и танками Abrams. Китай, Россия и другие держатели долларовых облигаций при этом финансировали войны США, скупая долг США. Тогда у них было мало реальных альтернативных вариантов.

Теперь, по иронии судьбы, две страны, которые в свое время продлили жизнь доллару (Россия и Китай после 1998 г.), рассматриваются большинством стран как потенциальные создатели жизнеспособной международной валюты, поддерживаемой золотом, нефтью, которая сможет снизить гегемонистскую роль доллара уже сегодня. Вот почему в течение нескольких последних лет, как Россия, так и Китай, Индия и ряд других стран, скупают огромные объёмы золота, в основном, чтобы пополнить валютные резервы своих ЦБ, которые до этого момента содержались, по большей части, в долларах и евро.

На фоне всего этого, США просто вынуждены проводить националистический курс развития, считают «нелигитимными» многие международные организации в их текущем виде и будут преследовать только свои собственные интересы. Об этом буквально заявил в своем выступлении на 73-й сессии Генеральной ассамблеи Организации Объединенных Наций Дональд Трамп. Помимо Всемирной торговой организации критике со стороны Трампа также подверглись Совет ООН по правам человека и Международный уголовный суд (также известный как Гаагский трибунал). Высказывания об отказе США от «глобализма» в пользу «патриотизма» ранее неоднократно звучали в комментариях и экс-советника президента США Стивена Бэннона [9].

Отметим, что заявление об односторонних действиях США справедливо не только в плане финансово-экономического давления 
в виде санкций в отношении таких стран как Китая, России, Ирана и Турции. В отношении многих других стран американские власти так же установили торговые ограничения в виде повышения импортных пошлин: речь идёт об Индии, Китае, Канаде, России, Турции, странах Европейского союза. А здесь уже американская уверенность в собственной исключительности привела к интересным последствиям: в США думали, что ради возможности сохранить хорошие отношения с «вашингтонским обкомом» элиты самых разных стран, от России и Китая до Евросоюза и Ирана, поднимут бунт против политического руководства своих стран. На практике же получилось нечто иное: США в глобальном мире были всеобщим примером, а стали всеобщей проблемой. И рано или поздно для этой проблемы найдётся адекватное решение.

Таким образом, и что можно уже констатировать, поведение нынешних американских властей стало «односторонним и безответственным». А та экономическая война, которую стремятся развязать сегодня США, нанесёт ущерб всем странам, которые будут в неё вовлечены. Нынешний односторонний и безответственный подход правительства США всё больше и больше втягивает мир в период беспощадной экономической войны. Поэтому, все те страны, которые имеют ориентированную на экспорт модель роста своей экономики, уже сегодня должны совместно объединить свои усилия с другими ответственными государствами для запуска мер по защите всех заинтересованных государств в целях предотвращения в будущем подобных разрушительных торгово-экономических и политических конфликтов. И дедолларизация мировой экономики при этом - это неизбежный этап для достижения значительного экономического суверенитета в будущем.

\section{Библиографический список}

1. Киевич А.В. Программа вновь избранного президента США как олицетворение изменений на макроэкономическом уровне глобальной экономики // Современные аспекты экономики. 2016. № 11 (231). C. 12-24.

2. Аналитический обзор vestifinance.ru. Электронный ресурс. Доступно на: https://www.vestifinance.ru/ articles/107475. - Дата доступа: 27.09.2018 г.

3. Киевич А.В. МИРОВЫЕ ЦБ В ЛОВУШКЕ QЕ. // В книге: Банковская система: устойчивость и перспективы развития. Сборник научных статей восьмой международной научно-практической конференции по вопросам банковской экономики, посвященной году науки в Беларуси. Полесский государственный университет. 2017. С. 72-76.

4. Аналитический обзор vestifinance.ru. Электронный ресурс. Доступно на: https://www.vestifinance.ru/ articles/106875. - Дата доступа: 28.09.2018 г.

5. Там же

6. Там же

7. Аналитический обзор vestifinance.ru. Электронный ресурс. Доступно на: http://www.vestifinance.ru/ articles/91050.- Дата доступа: 18.09.2018 г. 13:12

8. Киевич А.В. Дедолларизация мировой экономики как объективная реальность // Вопросы экономики и права. 2017. № 108. С. 33-37.

9. Там же 


\title{
СЕКЬЮРИТИЗАЦИЯ БАНКОВСКИХ АКТИВОВ: ИННОВАЦИОННЫЕ ФИНАНСОВЫЕ ИНСТРУМЕНТЫ НА РЫНКЕ ИПОТЕКИ
}

\author{
(c) 2018 Янов Виталий Валерьевич \\ доктор экономических наук, профессор, заведующий кафедрой «Финансы и кредит» \\ Поволжский государственный университет сервиса \\ 445677, Самарская обл., г. Тольятти, ул. Гагарина, д. 4 \\ E-mail:kaf_fin@tolgas.ru
}

(c) 2018 Иноземцева Елена Юрьевна

кандидат экономических наук, доцент кафедры «Финансы и кредит»

Поволжский государственный университет сервиса

445677, Самарская обл., г. Тольятти, ул. Гагарина, д. 4

E-mail: inozemceva_e@mail.ru

Приоритеты социально-экономического развития и задачи обеспечения жильем населения РФ потребовало новых научных подходов. Изменение рыночной конъектуры привели к трансформации системы финансирования и кредитования объектов жилищного строительства, что оказало воздействие на механизм приобретение жилья гражданами страны.

Ключевые слова: секьюритизация, ипотечные бумаги, балансовая и внебалансовая секьюритизация, ипотечный кредит.

В деятельности государства одним из приоритетных направлений его функционирования является формирование соответствующих условий, позволяющих повысить доступность приобретения жилья для граждан. Допустимость на российском рынке жилой недвижимости является сложным многогранным индикатором, который отражает не только ход рыночных приобретений в жилищной сфере, её социальную направленность, но и связан с социально-экономическими процессами в обществе. Возможности улучшения жилищных условий осуществляется под воздействием процесса, в котором тесно переплетаются демографические, социально-экономические показатели уровня жизни населения, бюджетно-нормативная и кредитно-финансовая системы, ценовая и тарифная политики в сфере строительства жилой недвижимости и жилищно-коммунального обслуживания. Приобретение собственного жилья первоочередная потребность каждой семьи, без удовлетворения которой, теряются социальные приоритеты общества. В связи с этим, практическая реализация прав населения на жилую недвижимость является важной задачей социально-экономического развития. В зависимости от подходов её решения зависят объемы и темпы строительства жилья, уровень благосостояния населения, политические оценки и мотивация поведения.
Для эффективного жилищного строительства в России необходимо обобщить и использовать опыт ипотечного кредитования экономически развитых европейских стран в целях возможного его применения для повышения доступности жилья. Один из способов расширения масштабов доступности жилья, получившего развитие в развитых странах называется секьюритизацией, под которой понимается трансформация активов в рыночные ценные бумаги с последующей продажей их инвесторам. Секьюритизация, превращая недвижимость в долговые обязательства в форме ценных бумаг, способствует повышению их оборачиваемости, направляет в инфраструктуру фондового рынка. Секьюритизация это трансформация активов в более ликвидные, лучшего качества, востребованные рынком. Особо привлекательными для инвесторов являются активы, представленные ломбардными ценными бумагами, в число которых входят облигации с ипотечным покрытием «ВТБ 24» нескольких серий, облигации Банка Москвы. Задача секьюритизации сводится к выпуску высокорейтинговых бумаг с низкой доходностью. Типовая схема рефинансирования ипотечных кредитов представлена на рисунке 1 :

1,2,3. ипотечные банки группируют в управляющей компании ипотечные закладные типов A, Б, B;

4. управляющая компания передает паке- 
6

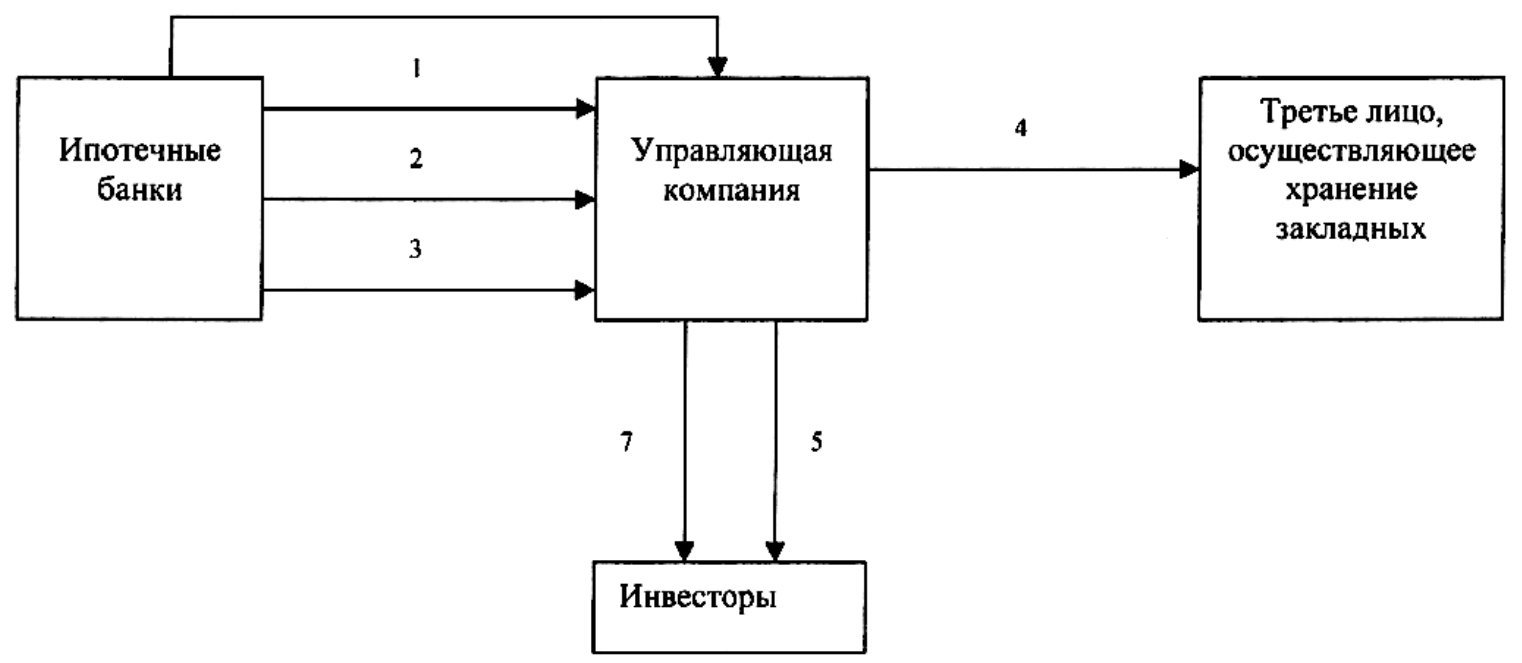

Puc. 1. Модель рефинансирование ипотечных кредитов путем обращения их в ценные бумаги.

ты закладных третьему лицу, осуществляющему хранение закладных;

5. управляющая компания выпускает на основе закладных ценные бумаги и продает их инвесторам;

6. ипотечный банк перечисляет в управляющую компанию платежи по ипотечным кредитам, полученные от заемщиков;

7. управляющая компания осуществляет выплату инвесторам доходов по ценным бумагам.

Процесс секьюритизации является сложной и многоэтапной процедурой, инициатором которой выступает коммерческий банк, предоставивший кредит на покупку недвижимости. Рефинансирование ипотечного актива позволит ему улучшить показатели ликвидности за счет продажи долгосрочных кредитов.

На первом этапе секьюритизации создается специальная управляющая компания, которая мобилизует ипотечные закладные и выпускает на их основе ценные бумаги. Это и позволяет отделить ипотечные активы от баланса банка-инициатора, а, следовательно, и всех причитающихся платежей по кредитам. Такая структура сделки дает инвесторам гарантию получения средств в случае финансовой несостоятельности банка-инициатора. Банки - держатели ипотечных закладных открывают для управляющей компании специальные накопительные счета, на которых сосредотачиваются все платежи, поступающие в уплату кредитов и процентов по ним. Далее средства распределяются среди инвесторов в качестве доходов по купленными ими ценным бумагам.
Предположим, что несколько ипотечных банков выдало различное количество долгосрочных займов типа А, Б и В.Данные займы различают как по сроку и величине ставки процента. Соответственно банки имеют ипотечные закладные типа А, Б и В. Закладные передаются в управляющую компанию, которая принимает на себя обязательство по передаче банкам через определенный, достаточно короткий срок соответствующую сумму денег. Контроль сроков является важным моментом, так как у банка всегда должно быть достаточно средств для своевременного исполнения своих обязательств. Все ипотечные закладные переходят на баланс управляющей компании, которая на следующем этапе секьюритизации объединяет закладные одного типа, полученные от разных банков, в пакеты типа А, Б и В. Таким образом, обязательства, имеющие разные характеристики, объединяются в одно, где в качестве должника выступают заемщики по ипотечным кредитам (т.е. несколько лиц), несущие долевую ответственность в рамках своего обязательства по договору займа. Прежде чем, ипотечные закладные будут объединены в единый пул они проверяются независимым оценщиком с целью определения степени их надежности. Подобное объединение не затрагивает положение должников, так как характер их ответственности и размер займа остались неизменны. Банки-инициаторы продолжают принимать платежи в счет погашения кредита от должников, но зачисляют их специальный накопительный счет управляющей компании.

На следующем этапе управляющая компа- 
ния передает сформированные пакеты третьему лицу на хранение и выпускает на их основе ценные бумаги, доходы от продажи которых являются средствами рефинансирования. Третье лицо служит хранителем закладных и гарантом выполнения компанией своих обязательств перед покупателями ее ценных бумаг.

В англо-американской системе права сделки секьюритизации сопровождаются созданием траст - агент или доверительного собственника, который и гарантирует передачу долговых обязательств собственникам ценных бумаг и осуществляет выплату доходов инвесторам-держателям ценных бумаг.

В зависимости от формы (модели осуществления) выделяют: балансовую и внебалансовую (традиционную) секьюритизацию активов. Под балансовой секьюритизацией активов понимают выпуск ипотечных ценных бумаг, обеспеченных залогом прав требования. При данной форме все выпущенные ценные бумаги остаются на балансе эмитента. Данная модель секьюритизации получила развитие в Германии и странах Скандинавии. Типичным примером такой секьюритизации является немецкая схема Pfandbrief, в которой активы находятся на определенных статьях баланса и не могут использоваться в других целях. Одновременно банк выпускает облигации, гарантирующие первоочередное право требования держателя на вышеуказанные активы в случае банкротства эмитента.

Рисунок 2.1:

1. Выдача ипотечных ссуд заемщикам.

2. Выпуск и размещение ценных бумаг, обеспеченных будущими поступлениями по ссудам.

3. Получение денежных средств от инвесторов в оплату ценных бумаг.

4. Выполнение заемщиками обязательств по уплате процентов и части основной долга по кредиту.

5. Выплата доходов инвесторам в виде купона и частичное погашение номинала ценных бумаг.

6. Переход прав требований по ссудам к инвесторам в случае банкротства банка (секьюритизируемые активы выделяются из конкурсной массы).

Стоит отметить, что ипотечные кредиты, оставшиеся на балансе банка, переводятся в отдельный реестр учета ипотечного обеспечения и находятся под постоянным контролем независимого поверенного, назначаемого либо самим банком или органом, контролирующем его деятельность.

Внебалансовую (традиционной) секьюритизацию определяют как инновационный способ финансирования, позволяющий рефинансировать ипотечные кредиты, имеющиеся у банка (оригинатора), за счет передачи прав требований специально созданной инвестиционной компании (special - purpose vehicle, SPV), финансирующей приобретение активов при помощи выпуска долговых инструментов (рис. 2.3). Средства, получаемые от размещения ценных бумаг SPV передает оригинатору в счет оплаты прав требования. В дальнейшем выплата основного долга и процентов держателям ценных бумаг осуществляется за счет поступлений от кредитов, права требования, но которым переданы SPV. Модель внебалансовой секьюритизация применяется в таких странах как США, Австралия, Великобритания, а также в ряде стран Азии и Латинской Америки. Внебалансовая секьюритизация включает в себя следующие этапы:

1. банк - первичный кредитор выдает ипотечные кредиты заемщикам, получая тем самым право на платежи по кредиту и право залогодержателя;

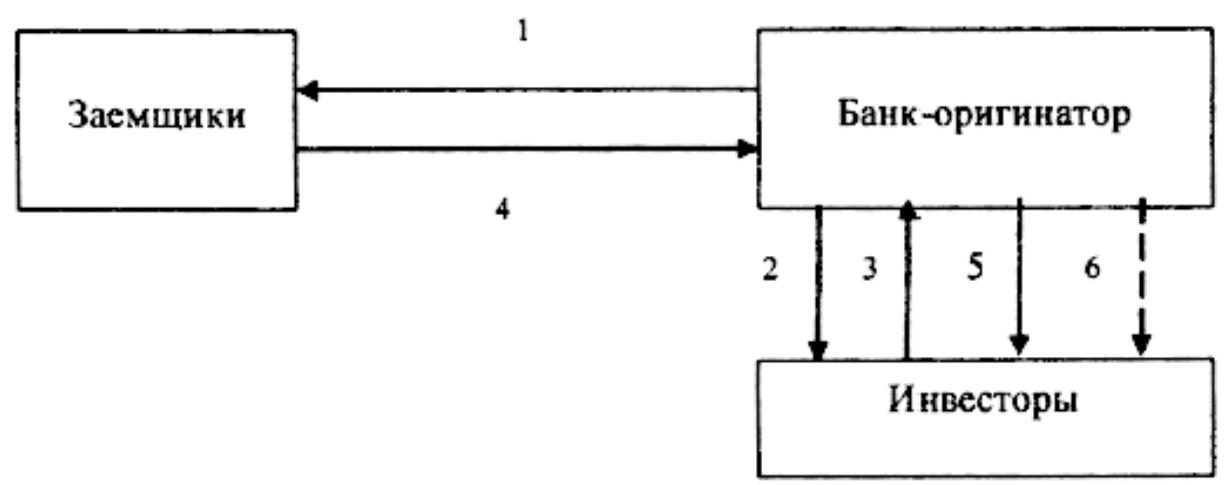

Рис. 2.1. Балансовая секьюритизация банковских активов 
2. специально созданная организация, SPV, приобретает у банка - кредитора права требования по кредитам, а так же права залогодержателя. При этом банк продолжает обслуживание кредитов, а так же осуществляет процедуру обращения взыскания на залоговое обеспечение, в случае если должник по ипотечному кредиту, входящему в пул, перестает выполнять свои обязательства;

3. на основе пула однотипных кредитов, SPV, выпускает ценные бумаги и продает их инвесторам.

Первый опыт создания SPV принадлежит США, а именно таким организациям как FNMA («Фэнни Мэй»), GNMA («Джинни Мэй») и FHLMC («Фредди Мак»), которые пользуются поддержкой государства.

Рисунок 2.2:

1. Предоставление кредитов заемщикам.

2. Создание пула ипотечных кредитов и их передача специально созданной проектной компании (SPV).

3. Предоставление кредитной поддержки (крупные банки, специализированные страховые компании).

4. Предоставление консультаций при структурировании сделки и присвоение кредитного рейтинга выпущенным SPV ценным бумагам.
5. Выпуск и продажа ценных бумаг инвесторам.

6. Поступление средств в оплату купленных инвесторами ценных бумаг.

7. Оплата переданного SPV пула ссуд.

8. Выполнение заемщиками обязательств в части уплаты процентов по кредиту и части основной суммы.

9. Перечисление SPV всех потоков по кредитам, вошедших в пул.

10. Выполнение обязательств перед инвесторами в виде выплат купонных платежей и части номинала ценных бумаг.

11. Оплата вознаграждения за кредитную поддержку.

12. Выплаты рейтинговому агентству.

13. Перечисление остаточной прибыли банку-оригинатору.

На основе особенностей рассмотренных моделей секьюритизации можно отметить следующие отличия (табл. 1).

Традиционной модели секьюритизации присущ и ряд недостатков: высокие затраты на обеспечение подлинной продажи, особенности в налоговом учете, раскрытие конфиденциальной информации о заемщике и т.д. Применение получивших широкое распространение в мировой практике схем секьюритизации банковских активов в России затруднено целым рядом обстоя-

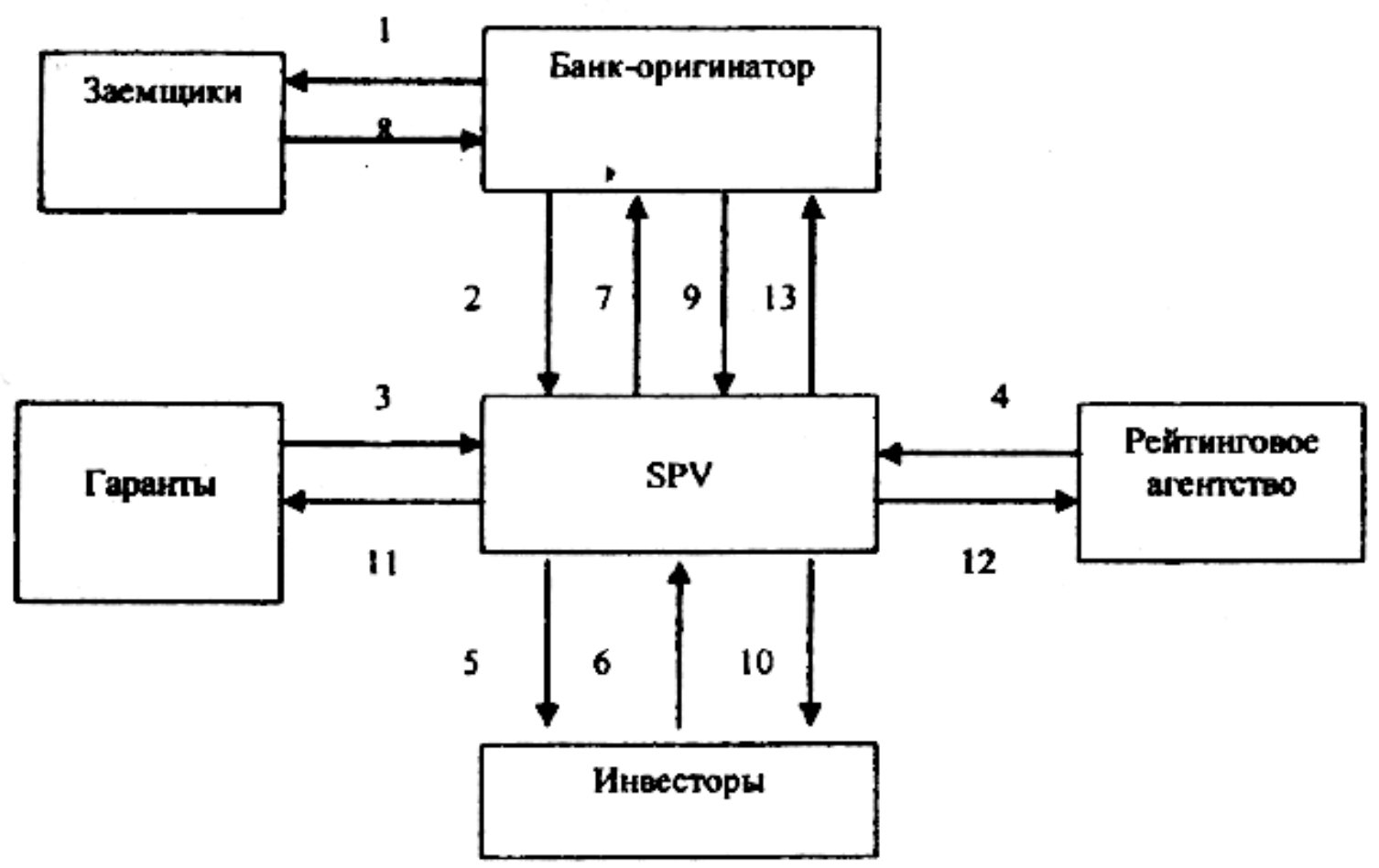

Puc. 2.2. Внебалансовая секьюритизация активов 
Таблица 1. Сравнение содержания балансовой и балансовой секьюритизации активов

\begin{tabular}{|c|c|c|}
\hline \multirow{2}{*}{ Критерии секьюритизации } & \multicolumn{2}{|c|}{ Вид секьюритизации } \\
\hline & Балансовая & Внебалансовая \\
\hline $\begin{array}{l}\text { Нахождение прав требований по } \\
\text { ипотечным кредитам }\end{array}$ & На балансе первичного кредитора & $\begin{array}{l}\text { Списываются с баланса первично- } \\
\text { го кредитора и передаются специ- } \\
\text { ализированной организации }\end{array}$ \\
\hline $\begin{array}{l}\text { Объем ответственности оригина- } \\
\text { тора }\end{array}$ & Отвечает собственным капиталом & $\begin{array}{l}\text { В рамках покрытия по кредитам и } \\
\text { дополнительного обеспечения }\end{array}$ \\
\hline $\begin{array}{l}\text { Кредитный рейтинг выпускаемых } \\
\text { бумаг }\end{array}$ & $\begin{array}{l}\text { Зависит только от рейтинга ориги- } \\
\text { натора }\end{array}$ & $\begin{array}{l}\text { Высокий рейтинг обеспечивается } \\
\text { высоким рейтингом оригинатора и } \\
\text { мерами кредитной поддержки }\end{array}$ \\
\hline $\begin{array}{l}\text { Риск досрочного погашения обяза- } \\
\text { тельств }\end{array}$ & Несет банк-эмитент & Приходится на инвестора \\
\hline Риск задержки выплат & $\begin{array}{l}\text { Может возникнуть в случае кон- } \\
\text { курсного производства в отноше- } \\
\text { нии оригинатора }\end{array}$ & Полностью исключен \\
\hline Кредитный риск & $\begin{array}{l}\text { Не передается и возлагается на } \\
\text { банк-эмитент }\end{array}$ & $\begin{array}{l}\text { Передается гарантам и/или страхо- } \\
\text { вой организации }\end{array}$ \\
\hline $\begin{array}{l}\text { Порядок погашения выпускаемых } \\
\text { ценных бумаг }\end{array}$ & $\begin{array}{l}\text { Единовременным платежом, без } \\
\text { досрочного погашения }\end{array}$ & $\begin{array}{l}\text { Выплаты в установленные сроки; } \\
\text { возможно досрочное погашение }\end{array}$ \\
\hline
\end{tabular}

тельств. Это и несовершенство законодательства (особенно в части судебной защиты срочных сделок), и неясность механизма налогообложения сделки по продаже активов SPV, а также неразвитость российского фондового рынка. К тому же необходимым для секьюритизации пулом низкорисковых стандартизированных ссуд размером в 100-150 млн. долл. обладает лишь незначительное число российских банков.

Между тем, образование в последние годы целой группы крупных институциональных инвесторов, нуждающихся в долговременных инструментах вложения средств (пенсионные фонды, паевые инвестиционные фонды, Агентство по страхованию вкладов), требует скорейшей выработки законодательного обеспечения сделок по секьюритизации активов и торговле кредитными деривативами. Первым шагом в практической деятельности по организации секьюритизации активов стало принятие Федерального закона «Об ипотечных ценных бумагах». Несмотря на то, что данный закон регламентирует только секьюритизацию ипотечных ссуд, он играет существенную роль в части применения зарубежного опыта в условиях российской экономики. Опыт первых сделок секьюритизации ипотечных активов, его анализ, позволят сформировать базу для разработки положений, регламентирующих и другие виды секьюритизации.

Таким образом, в условиях усиления турбулентности глобальной рыночной экономики задача государства сводятся к обеспечению платежеспособного спроса различных слоев населения на рынке жилья путем создания благоприятных условий для развития рыночных механизмов мобилизации внебюджетных ресурсов общества и направления их в кредитно-финансовую сферу посредством развития долгосрочного жилищного ипотечного кредитования, перехода к приобретению населением жилой недвижимости за счет собственных средств.

\section{Библиографический список}

1. Федеральный закон от (ред. от 29.06.2015) «Об ипотечных ценных бумагах» [Электронный ресурс]: федер. закон от 11.11.2003 N152-Ф3 // Консультант Плюс. - Режим доступа: http://www.consultant.ru/.

2. Проект Федерального закона «О секьюритизации» [Электронный ресурс] // Режим доступа: http://www.lin. $\mathrm{ru} /$

3. Развитие рынка ипотечного жилищного кредитования и деятельность $\mathrm{AO}$ «АИЖК» [Электронный ресурс] // Аналитический центр АО «АИЖК», Выпуск № 10, 2015 год.- Режим доступа: http://rusipoteka.ru/

4. «ВТБ 24» заложит ипотеку в ЦБ [Текст] // Ведомости. - № 3895 от 14.08.2015

5. Miquel Segoviano, Bradley jones, Petez Lindnez, and Johannes Blanrenheim, Securitization: The Road Ahead-IMF Discussion Note, January 2015

6. Securitization: The Road Ahead- IMF Staff discussion note 15/01/2015 
7. http://www. Americansecuritization.com/Recoutces/ASPX

8. http:// rusipotera/ru/files/analytics/

Поступила в редакцию 21.11.2018 



\section{ECONOMICS AND SOCIOLOGY}

№4 (40)

2018 



\section{CONTENTS}

\section{SOCIOLOGY}

\section{THEORY, METHODOLOGY AND HISTORY OF SOCIOLOGY}

Mostovaya I.V. Requirement of social cognition methodology . 74

Mitrofanova S.Y. The issue of childhood eventfulness in the foreign journals 74

SOCIAL STRUCTURE, SOCIAL INSTITUTIONS AND PROCESS

Soboleva I.V. Labor market competitiveness of women in the light of global trends 76

\section{ECONOMY.ECONOMIC SCIENCE}

\section{ECONOMIC THEORY}

Osipov V.S. Agrarian policy in emerging markets: choosing an institutional direction 76

Perepelkin V.A., Frolova K.A., Mukhamadieva L.N. Crowdinvesting as a new way of financing innovative projects

\section{ECONOMICS AND MANAGEMENT OF NATIONAL ECONOMY}

Bazadze N.G. Formation of organizational culture of corporations of defense industries 77

Beliaeva E.Y. New approach to innovations in Russian investment and construction complex .... 78

Ketova N.P., Ovchinnikov V.N. Functioning of ethno-markets in the economy of the regions of the south of Russia

\section{FINANCE, MONEY CIRCULATION AND CREDIT}

Podkopaeva E.V. Systemic problems in the way of increasing the efficiency of the subsequent internal state financial control

Livensky V.M. De-dollarization of world economy as a factor of counteraction to US aggressive policy

Yanov V.V., Inozemtseva E.Y. Securitization of bank assets: innovative financial instruments in the mortgage market 


\title{
SOCIOLOGY
}

\section{THEORY, METHODOLOGY AND HISTORY OF SOCIOLOGY}

\section{REQUIREMENT OF SOCIAL COGNITION METHODOLOGY}

\author{
(C) 2018 Mostovaya Irina Vladimirovna \\ Doctor of Sociology, Professor, Chief Researcher at Higher School of Business \\ South Federal University \\ 43, 23rd line, Rostov-on-Don, 344019, Russia \\ E-mail: mostovaya@sfedu.ru
}

The article is devoted to the analysis of the relevance of methodological search in the study of changes in social reality. We consider the relationship of identity and marginality, semantic translation of the cultural code in the process of generational shifts, tectonics of changes in lifestyle under the influence of the technological revolution.

Key words: sociology methodology, society, social identity, culture, lifestyle.

Received for publication on 07.11.2018

\section{THE ISSUE OF CHILDHOOD EVENTFULNESS IN THE FOREIGN JOURNALS}

(C) 2018 Mitrofanova Svetlana Yurievna

PhD in Sociological Sciences, Associate Professor of Department of Sociology and Cultural Studies Samara National Research University named after S.P. Korolev

34, Moscow highway, Samara, 443086, Russia

E-mail:mit_s@mail.ru

The article raises the theme of childhood eventfulness. It is proved that in modern society there are changes in the «normative» images of childhood, ideas about the eventfulness of childhood, the idea of multi-vector and plurality of models of child-adult relationships and growing up children on the base of abstracts and titles of articles of three foreign journals on childhood: «Childhood. A journal of global child research», «Global Studies of Childhood», «Children's Geographies».

Key words: eventfulness of childhood, foreign journals of childhood

Childhood is characterized by a constant focus on the adult world. The events of the child's life put the foundation for the development of his personality. According to this logic, when adult culture protects the boundaries of childhood, the eventfulness of the latter should be built taking into account the gradual development of sociality that focuses on the adult community. But, a number of authors talk about the transformation of sociality in the globalizing world, its limitation, reduction, that adult culture in modern society stop to keep the boundaries of childhood, the crisis of childhood, understanding this crisis as a crisis of the eventfulness of par- ent-child relations.

This issue will be considered on the basis of the appeal of research attention to the title and abstracts of articles of such foreign journals on childhood as «Childhood. A journal of global child research» and «Global Studies of childhood» publishing Sagepub, «Children's geography» publishing Routledge.

Questions of the eventfulness of childhood are somehow inscribed in such problems of research of foreign authors as: the study of the transition from childhood to adulthood, the concept of care in the relationship between parents and children, building 
a child's identity through work, gender dimensions of certain aspects of children's lives, etc.

Note that our analysis of the eventfulness of childhood shows that adult culture in modern society stop to hold the boundaries of childhood, and the very concept of childhood (as well as other concepts associated with human growth) becomes more vague, intermittent, fuzzy, amorphous. In our opinion, this thesis is confirmed by the results of studies conducted by foreign authors of individual events of children's lives, such as the experience of children's divorce of parents, work, alcohol consumption and others.

\section{References}

1. EHl'konin, B.D. Krizis detstva i osnovaniya proektirovaniya form detskogo razvitiya [EHlektronnyj resurs] // Voprosy psihologii. 1992. № 3. S.7-13. http://www.voppsy.ru/issues/1992/923/923007.htm (data obrashcheniya: 1 oktyabrya 2018)

[Elkonin, B.D. The crisis of childhood and the basis of the design of forms of child development. Questions of psychology[Electronic resource]. 1992. No. 3. Pp. 7-13. http://www.voppsy.ru/issues/1992/923/923007.htm (date of application: October 1, 2018).]

2. Majorova-SHCHeglova, S.N. Vliyanie sobytijnosti detstva pokoleniya Z na sociopsihologicheskie problemy studencheskoj zhizni: repernye tochki psihologicheskoj sluzhby vuza / Psihologicheskaya sluzhba universiteta: real'nost' i perspektivy. Materialy I Vserossijskoj nauchno-prakticheskoj konferencii s mezhdunarodnym uchastiem. 2017. S. 266-271.

[Mayorova-Shcheglova, S.N. Influence of the events of childhood generation Z on the socio-psychological problems of student life: reference points of the psychological service of the University [Text] / Psychological service of the University: reality and prospects. Materials of the I-st all-Russian scientific-practical conference with international participation. 2017. P. 266-271.]

3. Mitrofanova, S.YU. Markery «vzroslosti» i sobytiya detstva / Geografii detstva: mezhdisciplinarnyj sintez issledovatel'skih podhodov i praktik. Materialy mezhdunarodnoj molodezhnoj nauchnoj shkoly-konferencii. Otvetstvennyj redaktor A. G. Filipova. 2018. S. 159-162.

[Mitrofanova, S. Y. Markers of «adulthood» and the events of childhood [Text] / The geography of childhood: an interdisciplinary synthesis of research approaches and practices. The Materials of the international youth scientific school-conference. Responsible editor - A. G. Filippova. 2018. P. 159-162.]

4. Marschall A. Who cares for whom? Revisiting the concept of care in the everyday life of post-divorce families // Childhood. 2014. Vol.21. Is.4. Pp. 517-531.

5. André G., Godin M. Child labour, agency and family dynamics. The case of mining in Katanga (DRC) // Childhood. 2014. Vol.21. Is.2. Pp. 161-174.

6. Sackey E. T., Johannesen B.O. Earning identity and respect through work: A study of children involved in fishing and farming practices in Cape Coast, Ghana // Childhood. 2015. Vol.22. Is.4. Pp. 119-133.

7. Holdsworth C., Laverty L., Robinson J. Gender differences in teenage alcohol consumption and spatial practices // Children's Geographies. 2017. Vol. 15. Is. 6. Pp.741-753.

8. Gill V., Jayne M., Gould M. The proximity effect: The role of the affective space of family life in shaping children's knowledge about alcohol and its social and health implications // Childhood. 2014. Vol.21. Is.2. Pp. 103-118.

9. Muldoon J.C., Williams J.M., Lawrence A. «Mum cleaned it and I just played with it»: Children's perceptions of their roles and responsibilities in the care of family pets // Childhood. 2015. Vol.22. Is.2. Pp. 201-216.

10. Voléry I. Sexualisation and the transition from childhood to adulthood in France: From age-related child development control to the construction of civilisational divides // Childhood. 2016. Vol.23. Is.1. Pp. 143-153.

11. Bhana D. Sex isn't better than love': Exploring South African Indian teenage male and female desires beyond danger // Childhood. 2016. Vol.23. Is.3. Pp. 362-377.

12. Marshall L. 'Going to school to become good people': Examining aspirations to respectability and goodness among schoolchildren in urban Ethiopia // Childhood. 2016 Vol.23. Is.3. Pp. 423-437.

13. Hatzigianni M. Transforming early childhood experiences with digital technologies // Global Studies of Childhood. 2018. Vol.8. Is.2. Pp. 173-183/

14. Dias P., Brito R., Ribbens $W$. The role of parents in the engagement of young children with digital technologies: Exploring tensions between rights of access and protection, from 'Gatekeepers' to 'Scaffolders' // Global Studies of Childhood. 2016. Vol.6. Is.4. Pp. 414-427. 
15. Nordbakke S. Children's out-of-home leisure activities: changes during the last decade in Norway[Electronic resource] // Children's Geographies. 2018 https://twitter.com/childrensgeogs (date of application: October 1, 2018).

16. Malmquist A., Möllerstrand A., Wikström M., Nelson K.Z. 'A daddy is the same as a mummy': Swedish children in lesbian households talk about fathers and donors // Childhood. 2014. Vol.21. Is.1. Pp. 119-133.

Received for publication on 09.10.2018

\title{
SOCIAL STRUCTURE, SOCIAL INSTITUTIONS AND PROCESS
}

\section{LABOR MARKET COMPETITIVENESS OF WOMEN IN THE LIGHT OF GLOBAL TRENDS}

\author{
(c) 2018 Soboleva Irina Viktorovna \\ Doctor of Economic Sciences, Chief research fellow \\ Institute of Economics of the Russian Academy of Sciences \\ 32, Nakhimovsky prospect, Moscow, 117418, Russia
}

The article examines factors and trends in competitiveness of women in modern economy. Based on the data of international studies it is shown that today the main factors reducing relative competitiveness of women as compared to men stem not from lower quality of female labor force but from gender stereotypes triggering mechanisms of gender discrimination that impede realization of women's human potential in the world of work.

Key words: competitiveness of women, labor market, gender gap, gender gap index, gender discrimination

Received for publication on 25.09.2018

ECONOMY.ECONOMIC SCIENCE

ECONOMIC THEORY

\section{AGRARIAN POLICY IN EMERGING MARKETS: CHOOSING AN INSTITUTIONAL DIRECTION}

\author{
(C) 2018 Osipov Vladimir Sergeevich \\ Doctor of Economics, Professor \\ Moscow State Institute of International Relations (University) of the Ministry for Foreign Affairs of \\ Russia (MGIMO) \\ 76, Vernadskogo pr., Moscow, 119454, Russia \\ E-mail:vs.ossipov@gmail.com
}

The article attempts to search for dysfunctions in the implementation of institutional reforms in the agro-food sector of emerging markets. On the basis of institutional analysis, two directions of institutional reforms have been identified - the Pigouvian and the Coasian, - by the names of outstanding theorists 
of institutional science (A. Pigou and R. Coase). The distinction between these directions and possible directions of realization of directions in the agrarian sphere is shown. The problem of trust in the agrarian economy is revealed. The restoration of trust is shown as a fundamental problem in the implementation of institutional reforms in the agrarian sector of the emerging market. Financing of the article is carried out within the state task No. 0163-2017-0005 "Scientific and technological development of economy of the branch markets".

Key words: institutional reform, the Pigouvian and the Coasian direction of institutional reforms, trust, agrarian market, infrastructure.

\title{
CROWDINVESTING AS A NEW WAY OF FINANCING INNOVATIVE PROJECTS
}

\author{
(C) 2018 Perepelkin Vyacheslav Aleksandrovich \\ Doktor of Economic Sciences, Professor of the Department of World Economy \\ Samara State Economic University \\ 141, Soviet Army Street, Samara, 443090, Russia \\ E-mail: slavaap@rambler.ru \\ (C) 2018 Frolova Kristina Alekseevna \\ Samara State Economic University \\ 141, Soviet Army Street, Samara, 443090, Russia \\ E-mail: kitty-kriska@mail.ru \\ (C) 2018 Mukhamadieva Liliia Nailevna \\ Samara State Economic University \\ 141, Soviet Army Street, Samara, 443090, Russia \\ E-mail:muhamadievalilli@mail.ru
}

The article focuses on studying crowdinvesting as a promising way of financing innovative projects. The features of crowdinvesting, its types, the potential for use in modern Russian economic conditions are analyzed.

Key words: crowdinvesting, crowdfunding, startup, investors, crowdinvesting platform, microfinance.

Received for publication on 07.11.2018

ECONOMICS AND MANAGEMENT OF NATIONAL ECONOMY

\section{FORMATION OF ORGANIZATIONAL CULTURE OF CORPORATIONS OF DEFENSE INDUSTRIES}

(c) 2018 Bazadze Natalya Grigoryevna

Doctor of Economics, Professor

Professor of Department of Management and Marketing of High-tech Industries

Moscow Aviation Institute (National Research University)

4, Volokolamsk Highway, Moscow, 125993, Russia

E-mail: n-bazadze@yandex.ru

Corporate culture in the defense industries should be formed and developed, first of all, in terms of 
the culture of work organization, production organization and management at earlier stages of the human resources life cycle - stages of training potential personnel.

Key words: corporate structures, specificity of defense industries, corporate culture, organizational culture, levels of manifestation of corporate culture, the formation of organizational and managerial competencies.

Received for publication on 07.11.2018

\title{
NEW APPROACH TO INNOVATIONS IN RUSSIAN INVESTMENT AND CONSTRUCTION COMPLEX
}

(c) 2018 Beliaeva Elena Yuryevna

Graduate Student of Department of Economics and Management of Enterprises and Industrial Complexes

Saint-Petersburg State University of Economics

21, Sadovaia str., Saint-Petersburg, 191023, Russia

E-mail: lenaprokopenkova@mail.ru

This article provides recent trends in the innovative and economic field of the construction industry. In particular, the objective of innovations application is updated and the principles for objective achievement in relation to investment construction complex from the theoretical side are offered. The practical side of a problem of innovations is also characterized and mechanisms of overcoming obstacles for an investment and construction complex are offered. Complex application of types of innovations is recommended.

Key words: investment and construction complex, innovations, economic effect, digitalization, social risks.

Received for publication on 07.11.2018

\section{FUNCTIONING OF ETHNO-MARKETS IN THE ECONOMY OF THE REGIONS OF THE SOUTH OF RUSSIA}

\author{
(C) 2018 Ketova Natalya Petrovna \\ Honored Scientist of the Russian Federation \\ Doctor of Economics, Professor, Head Department of Marketing and Communication in Business \\ South Federal University \\ 88, M. Gorky Street, Rostov-on-Don, 344002, Russia \\ E-mail:kmik2012@mail.ru \\ (c) 2018 Ovchinnikov Viktor Nikolaevich \\ Honored Scientist of the Russian Federation, \\ Doctor of Economics, Professor \\ Professor and Consultant of the Department of Development Management spatial and economic systems \\ South Federal University \\ 88, M. Gorky Street, Rostov-on-Don, 344002, Russia
}

The article presents the results of developing the problems: identifying the functional role of ethnic markets in the economy of the regions of southern Russia; identification of their positions and determination of vectors of orientation to meet the specific types of demand of target audiences of consumers.

Key words: regional economy, ethnic markets, target audiences, ethnic preferences of customers, orientation vectors, territorial space 
FINANCE, MONEY CIRCULATION AND CREDIT

\title{
SYSTEMIC PROBLEMS IN THE WAY OF INCREASING THE EFFICIENCY OF THE SUBSEQUENT INTERNAL STATE FINANCIAL CONTROL
}

\author{
(C) 2018 Podkopaeva Ekaterina Vyacheslavovna \\ Graduate Student, Department of State and Municipal Finance \\ St. Petersburg State University of Economics (UNECON) \\ 21, Sadovaya Street, St. Petersburg, 191023, Russian Federation \\ E-mail: podkopaeva2006@rambler.ru
}

The article is devoted to the study of the problem of the lack of the audit staff of the Federal Treasury, which directly performs the functions of the subsequent internal state financial control, as well as the problem of transparency of activities within such control. The article analyzes the practice of the Federal Treasury on the use of risk-based approach in the planning of control measures.The author's position in relation to the relationship between the amount of funding functions of internal state financial control, personnel hunger, formalism and declarative transparency in the activities of the body performing the functions of subsequent internal state financial control.

Key words: internal state financial control, Federal treasury, subsequent financial control. personnel hunger, the transparency of the activities of the authority

Received for publication on 11.11.2018

\section{DE-DOLLARIZATION OF WORLD ECONOMY AS A FACTOR OF COUNTERACTION TO US AGGRESSIVE POLICY}

\author{
(C) 2018 Livensky Valentin Mikhailovich \\ Candidate of Geographical Sciences, Associate Professor of the Department of Finance \\ Polessky State University \\ 23, The Dnieper Flotilla Street, Pinsk, 225710, Republic of Belarus \\ E-mail: livey@tut.by
}

The article analyzes the US foreign policy, trying to restrain the development of countries that they consider to be competitors in world markets; it is justified that a number of leading countries, in the foreseeing future negative consequences for the world economy, will pursue a policy of de-dollarization of their economies.

Key words: world economy, trade wars, sanctions, crisis, de-dollarization of economies.

Received for publication on 25.10 .2018

\section{SECURITIZATION OF BANK ASSETS: INNOVATIVE FINANCIAL INSTRUMENTS IN THE MORTGAGE MARKET}

(c) 2018 Yanov Vitaly Valeryevich

Doctor of Economics, Professor, Head of the Department of Finance and Credit

Volga State University of Service

4, Gagarin, Tolyatti, 445677, Russia 


\section{(C) 2018 Inozemtseva Elena Yuryevna}

Ph.D. in Economics, Associate Professor of the Department of Finance and Credit

Volga State University of Service

4, Gagarin, Tolyatti, 445677, Russia

The priorities of socio-economic development and the problem of housing the population of Russia has demanded new scientific approaches. Changing market conjectures led to the transformation of the system of financing and lending to housing projects that have an impact on the mechanism housing nationals.

Key words: securitization, mortgage securities, and off balance sheet securitization of mortgage credit.

Received for publication on 21.11.2018 